\author{
Argonne National Laboratory \\ 9700 S. Cass Avenue \\ Argonne, Illinois 60439
}

\begin{abstract}
VOLUME ESTIMATE OF RADIUM-CONTAMINATED SOIL IN A SECTION OF BARROWS FIELD PARK, GLEN RIDGE, NEW JERSEY
\end{abstract}

\author{
NOVEMBER - DECEMBER 1989 \\ by
}

M. J. Robinet and G. D. Mosho

Environment, Safety, and Health Department

ANL Field Team
M. J. Robinet
G. D. Mosho
D. W. Reilly
J. H. Vacca

April 1990

Work sponsored by

U. S. Environmental Protection Agency Environmental Studies and Statistical Branch Analysis and Support Division Office of Radiation Programs 
ABSTRACT . . . . . . . . . . . . . . . . . . . . . . . . vii

BACKGROUND AND OBJECTIVE . . . . . . . . . . . . . . . . . . . . . . 1

METHODOLOGY AND INSTRUMENTATION. . . . . . . . . . . . . . . . . . . . 3

SELECTION OF TUBE LOCATIONS. . . . . . . . . . . . . . . . . . . . . . . 5

Coordinate System. . . . . . . . . . . . . . . . . . . 5

Surface Scan . . . . . . . . . . . . . . . . . . . . 5

Tube Spacing... . . . . . . . . . . . . . . . . . . 7

CONTAMINATION-DEPTH-PROFILE DATA . . . . . . . . . . . . . . . . . . . 11

CORRELATION OF COUNT RATE AND ACTIVITY CONCENTRATION . . . . . . . . . 16

DEPTHS TO CRITERIA . . . . . . . . . . . . . . . . . . . . . . . . . . 17

CALCULATION OF VOLUMES . . . . . . . . . . . . . . . . . . . . . . . . 30

RESULTS. . . . . . . . . . . . . . . . . . . . . . . . . . . 30

QUALITY ASSURANCE. . . . . . . . . . . . . . . . . . . . . . . . . . 31

ACKNOWLEDGMEYTS. . . . . . . . . . . . . . . . . . . . . . . . . 32

REFERENCES . . . . . . . . . . . . . . . . . . . . . . . . . 33

APPENDIX A: List of Field Instruments and Equipment. . . . . .. . . . 34

APPENDIX B: Graphs of Contamination Depth Profiles . . . . . . . . . 37

APPENDIX C: Depths to Maximum Concentrations . . . . . . . . . . . . 69

INDEX. . . . . . . . . . . . . . . . . . . . . . . . . . . . . . 74

\section{LIST OF FIGUREES}

\section{Figure}

Page

1. Location of Glen Ridge, New Jersey. . . . . . . . . . . . . . 2

2. Electrical Metal Tube with Point. . . . . . . . . . . . . . . 3 
3. Cross Section of Scintillation Detector

Used in Driven Tubes. . . . . . . . . . . . . . . . . . . . . 4

4. Detector and Rate Meter/Scaler Used to

Measure Depth Profiles of Radium Contamination. . . . . . 5

5. Location of Test Area in Barrows Field Park . . . . . . . . 6

6. Radiation-Relative Count Rates Detectable Aboveground (Few Inches from Surface) . . . . . . . . . 8

7. Radiation Exposure Rates at Three Feet Above Surface . . . . . . . . . . . . . . . . . . 9

8. Locations of Driven Tubes and Soll Samples in Test Area. . . . . . . . . . . . . . . . . . . 10

9. Example of Contamination-Depth Profile

(Count Rate Vs. Depth) . . . . . . . . . . . . . . . 11

10. Comparison of Equation 1 to Soil-Sample Data from Test Area . . . . . . . . . . . . . . . . . 15

11. Example of Contamination-Depth Profile (pCi/g Vs. Depth) . . . . . . . . . . . . . . .

12. Determination of Depth-to-Concentration Criteria. . . . . . . . . . . . . . . 17

13. Depths to $5 \mathrm{pCi}-226 \mathrm{Ra} / \mathrm{g}$. . . . . . . . . . . . 19

14. Depths to $15 \mathrm{pCi}-22{ }^{\circ} \mathrm{Ra} / \mathrm{g} . . . . . . . . . . . . .20$

15. Determination of Depths to Top and Bottom of $\geq 200 \mathrm{pCi} / \mathrm{g}$ Layer of Soil. . . . . . . . . . . . . . . . 21

16. Determination of Depths to Top and Bottom of $\geq 300 \mathrm{pCi} / \mathrm{g}$ Layer of Soil. . . . . . . . . . . . . . . . 22

17. Depths to Top of $\geq 200 \mathrm{pCi} / \mathrm{g}$ Layer. . . . . . . . . . . 23

18. Depths to Bottom of $\geq 200 \mathrm{pCi} / \mathrm{g}$ Layer . . . . . . . . . . 24

19. Thickness of $\geq 200 \mathrm{pCi} / \mathrm{g}$ Layer. . . . . . . . . . . 25

20. Depths to Top of $\geq 300 \mathrm{pCi} / \mathrm{g}$ Layer. . . . . . . . . . . . 27 


\section{LIST OF FIGURES (cont'd.)}

Figure

$\underline{\text { Page }}$

21. Depths to Bottom of $\geq 300 \mathrm{pCi} / \mathrm{g}$ Layer . . . . . . . . . . . 28

22. Thickness of $\geq 300 \mathrm{pCi} / \mathrm{g}$ Layer. . . . . . . . . . . . . . . 29

B1-B30. Concentration-Depth Profiles at Barrows Field Park,

Glen Ridge, New Jersey. . . . . . . . . . . . . . . . . 38-68

\section{LIST OF TABLES}

Table

Page

1. Example of Contamination-Depth-Profile Data . . . . . . . . 12

2. Radium Concentration in Soll Samples from

Test Area in Barrows Field Park . . . . . . . . . . . . . . 14

C1. Depths to Maximum Concentrations. . . . . . . . . . . . . 70-73 
VOLUME ESTIMATE OF RADIUM CONTAMINATED SOIL IN A SECTION OF

BARROWS FIELD PARK, GLEN RIDGE, NEW JERSEY

November - December 1989

by

M. J. Robinet and G. D. Mosho

\section{ABSTRACT}

The objective of this project was to estimate the in-place volume of radium-contaminated soil in an area of Barrows Field Park, Glen Ridge, New Jersey. The information was necessary to determine whether or not there was sufficient soil with the proper radium concentration to test a new method of soil decontanination. The optimum concentration for the test was determined by the U.S. Environmental Protection Agency to be less than or equal to $200 \mathrm{pCi}-2{ }^{\circ} \mathrm{Ra} / \mathrm{g}$ of soil.

The steps used by Argonne National Laboratory personnel to obtain the required data for estimating the volume of contaminated soil was to (1) measure the contamination-depth profile at 118 locations in a $60 \mathrm{ft} x 150 \mathrm{ft}$ area in the park, (2) plot the contours of depths to the specified concentration, and (3) measure the area of the closed depth contours.

The in-place volume of contaminated soil is calculated from the product of the contamination depths and the contour areas associated with each depth.

The depth profiles were measured by taking radiation measurements inside one-in dia. metal tubes at depth increments below the surface. The 1 in dia. tubes were 5 to $10 \mathrm{ft}$ long and were driven into the ground with a gasolinepowered portable hammer.

The data collected show that the tested area in Barrows Field Park has at least 1000 cubic yards of soil with radium concentrations equal to or less than $200 \mathrm{pCi} / \mathrm{g}$ of soil. 


\section{BACKGROUND AND OBJECTIVE}

Barrows Field Park is in a residential area of Glen Ridge, New Jersey, which is less than 20 miles west of New York City (Fig. 1). Areas of the park are contaminated with radium because a former stream bed was filled in some time ago with radium-contaminated debris and soil. The origin of the contamination is believed to be from the former radium-processing facilities that existed in the area.

The areas of contamination in the fark were previously identified by government agencies and by private firms. Two recent radiation surveys were performed by the firm of Camp, Dresser and Mckee, Inc., and by the $U$. $S$. Environmental Protection Agency (EPA), Eastern Environmental Radiation Facility (CDM-89; EERF-89).

Volume estimates of contaminated soil are usually done to predict cleanup cost. However, in this case, the objective was to find sufficient contaminated soil to test a new soil decontamination process. The park was chosen as a potential source of contaminated soil because of previous data on concentration levels and because it was on public rather than private property. The soil-decontamination test required at least 1000 cubic yards of soil with radium concentrations between 5 and $200 \mathrm{pCi} / \mathrm{g}$. The profiles of radium contamination-to-depth in a rectangular area across the park will be used to define the boundary of excavation limits and to locate local radium concentrations that exceed $200 \mathrm{pCi} / \mathrm{g}$.

The purpose of this report is to describe the method used to make the volume estimates and to document the results. All data were collected by the Argonne National Laboratory (ANL) field team between November 28 and December 1, 1989. 


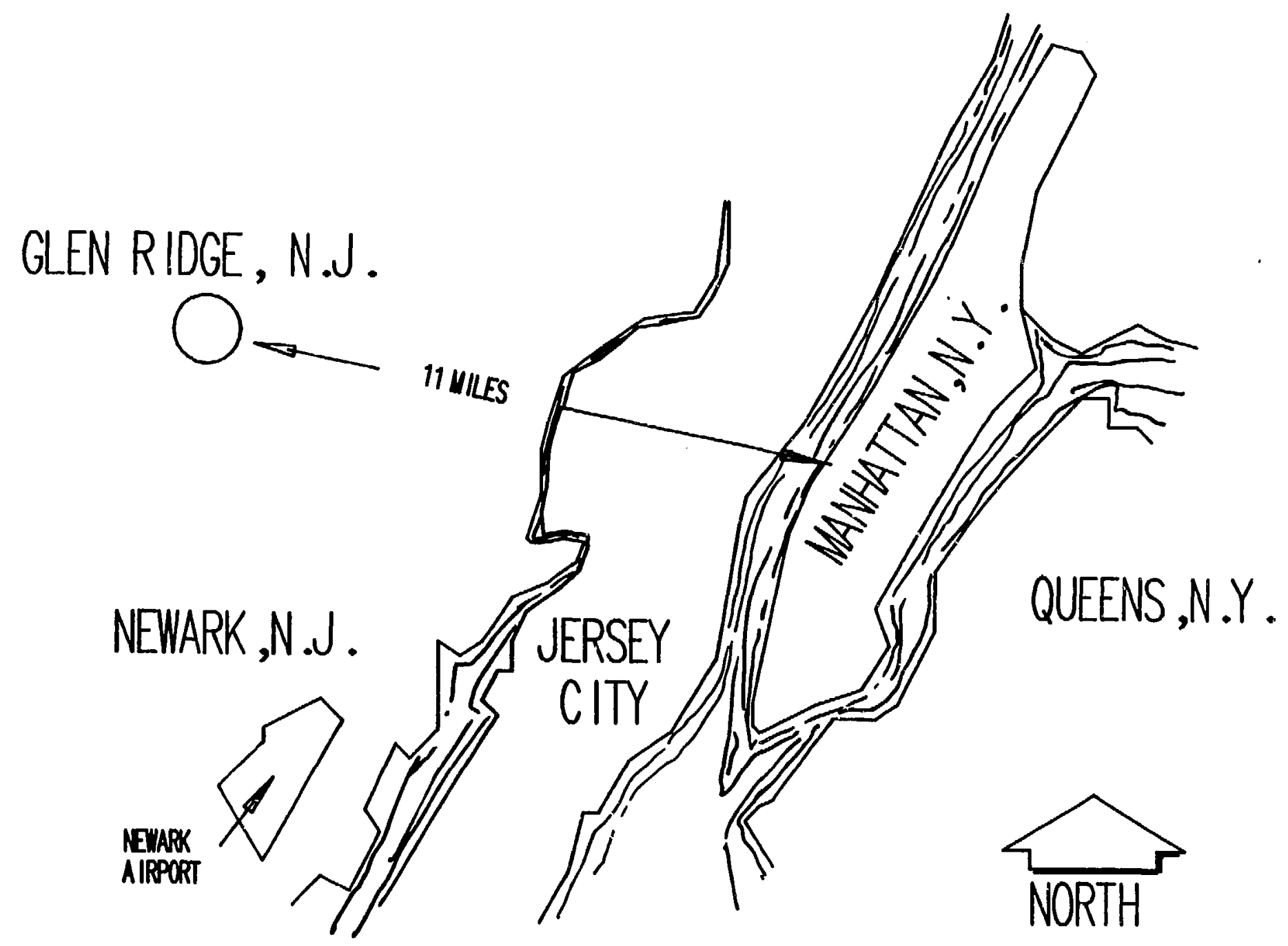

Figure 1. Location of Glen Ridge, New Jersey. 


\section{METHODOLOGY AND INSTRUMETTTATION}

To estimate the in-place volume of radium contaminated soil, the depth profile of radium concentrations must be determined. The technique used by ANL to measure contamination profiles was to drive 1 in-dia. tubes into the ground and to take radiation measurements (count rate) in the tubes at depth increments with a collimated radiation detector. The tubes used are 1 in-dia. standard Electrical Metal Tubing (EMT) and are driven with a portable gasoline-powered hammer. One-inch EMT has a nominal inside diameter of 1.049 inches and has a wall thickness of 0.057 inch. The standard length is 10 feet. Steel points are placed on the tubes to facilitate driving and extraction in dense soil (FIg. 2). Tubes are typically driven in 5 or $10 \mathrm{ft}$ sections. Couplings are used to drive tubes to 15 or 20 feet.

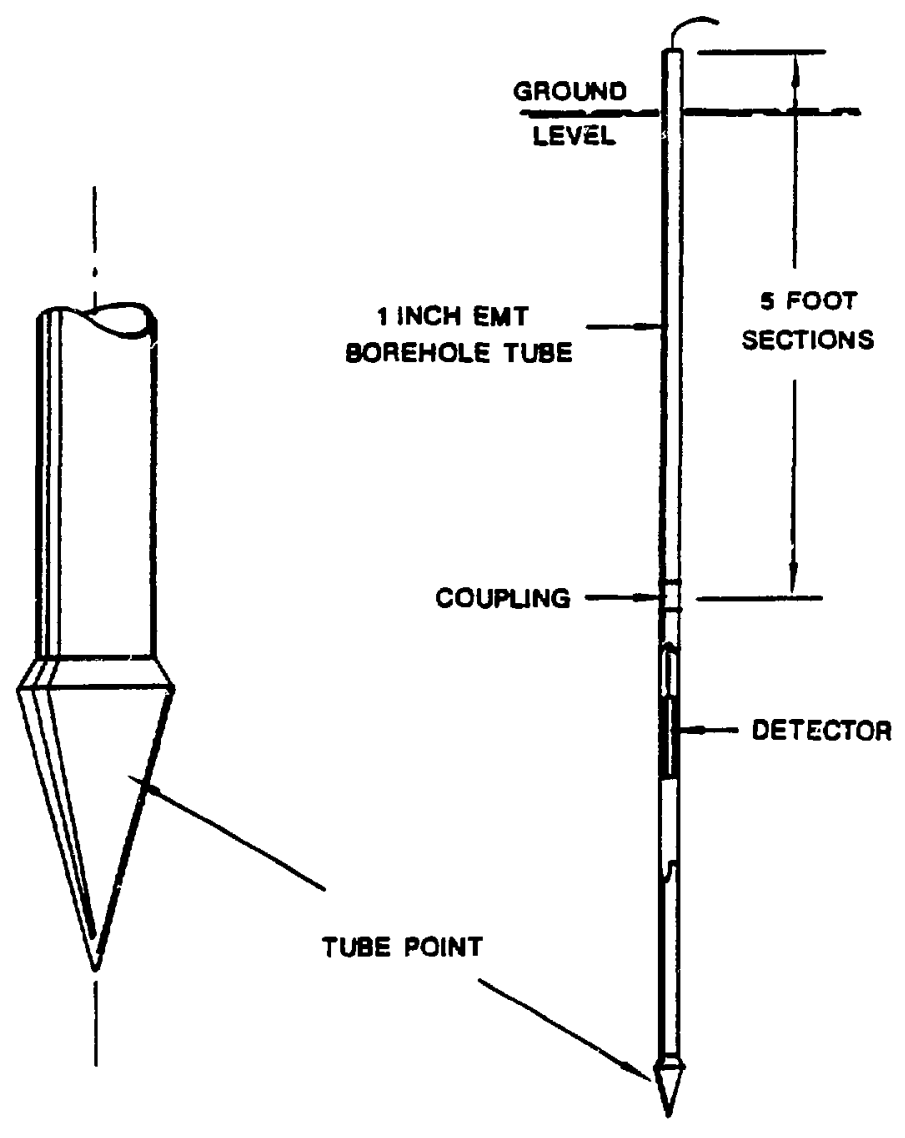

Figure 2.

Electrical Metal Tube With Point. 
The detector used for radiation measurements in the tubes has a $3 / 8$ in-dia. $x 3 / 8$ in-long $N a I(T /)$ crystal coupled to a $1 / 2$ in photomultiplier (FIg. 3). Readout frcm the detector was provided by a Ludlum Model 2220 or Model 2221 rate meter/scaler. A photograph of the detector and the rate meter/scaler is shown in Fig. 4. The detector was collimated to make its view primarily sideways and to reduce the down-looking view so it "saw" a thin doughnut-shaped layer of soll. The detector and 1 ts readout system were frequently checked against a ${ }^{137} \mathrm{Cs}$ check source to assure that measurements were repeatable.

A list of other field instruments and equipment used to obtain and analyze the data is given in Appendix $A$.

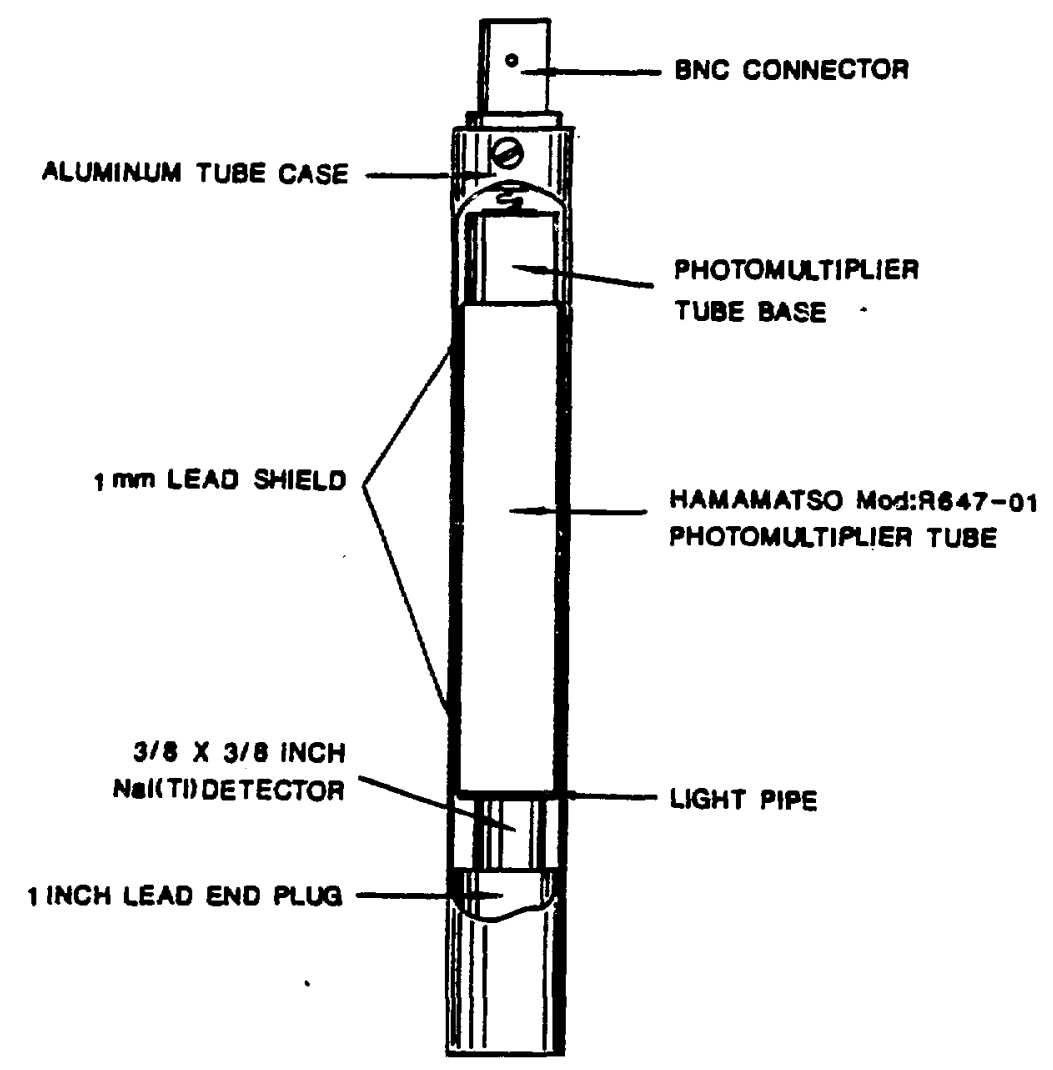

Figure 3. Cross Section of Scintillation Detector Used in Driven Tubes. 


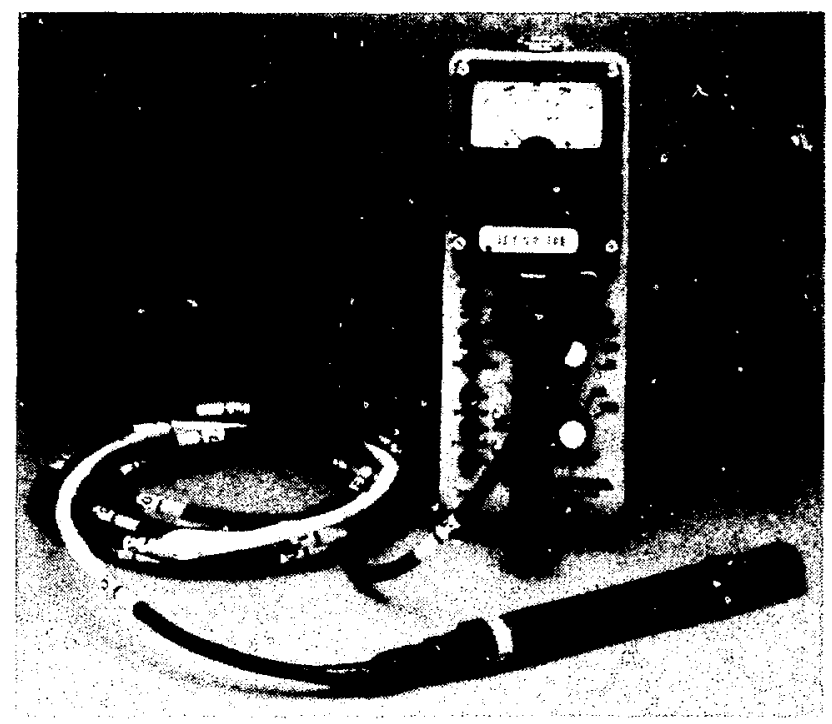

Figure 4. Detector and Fate Meter/Scaler Used to Measure Depth Profiles of Radium Contamination.

\section{SELECTION OF TUBE LOCATIONS}

COORDINATE SYSTEM - A rectangular coordinate system with $10 \mathrm{ft} \times 10 \mathrm{ft}$ grids was staked out in the designated test area of the park to identify the location of all measurements and soil samples. Locations were identified by East, North, $Z$ coordinates, where $Z$ is the depth below the existing grade. The location of the test area in Barrows Field Park is shown in Fig. 5.

SURFACE SCAN - The initial criterion for tube location was to place a tube at each $20 \mathrm{ft} \times 20 \mathrm{ft}$ grid intersection and at radiation anomalies ("hot spots") between grid intersections. Anomaljes were identified by scanning the entire test area with a collimated "down-looking" radiation detector (Eberline PG-2). A flag was placed at each hot spot. 


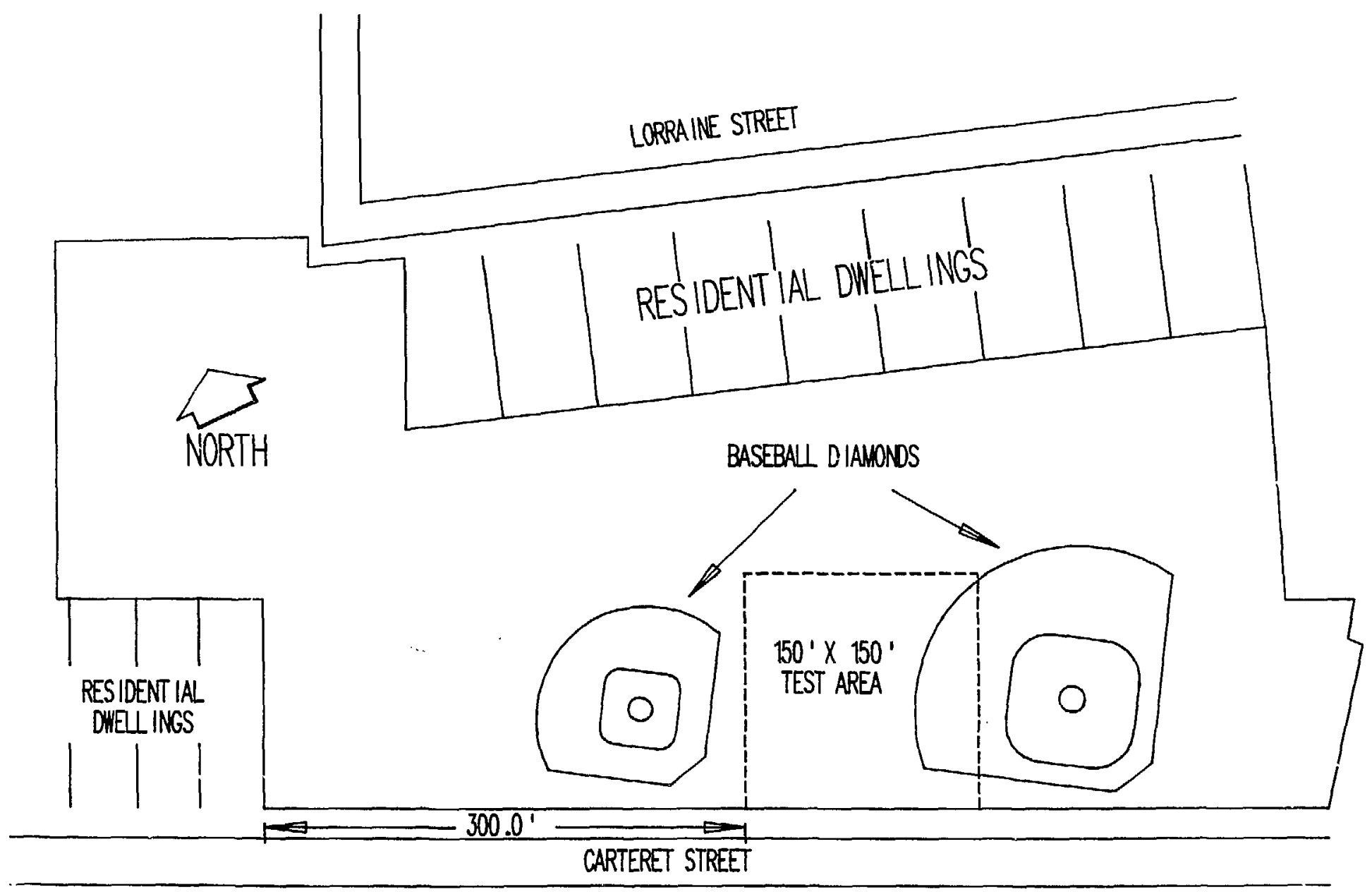

Figure 5. Location of Test Area in Barrows Field Park. 
After each hot spot was identified, aboveground radiation measurements were taken at each $10 \mathrm{ft} \times 10 \mathrm{ft}$ grid intersection with the same collimated decector and also with an exposure-rate meter. These data were used to plot the contours of contamination which was detectable aboveground.

The collimated detector (Eberline PG-2) had a $2 \mathrm{~mm} x 50 \mathrm{~mm}$ dia. $\mathrm{NaI}(\mathrm{T} L)$ crystal with readout to a single channel analyzer and rate meter (Eberline PRM-5-3). The lead collimator on the detector was about $10 \mathrm{~mm}$ thick and the analyzer was operated in the gross mode with the peak set at $60 \mathrm{keV}$. When used for scanning (finding contamination), the detector is held as close to the ground as practinal and is swung in a vertical arc which reaches a maximum angle of about $45-50$ degrees from the verticle (while walking).

Because this instrument (Eberline PG-2 with PRM-5-3) was used only to locate anomalies and to determine the contours of aboveground detectable contamination, it is only the relative count rate that is of interest. A map of the relative count rates in the test area is shown in Fig. 6 .

The exposure-rate meter used to take radiation exposure-rate measurements at each $10 \mathrm{ft} \times 10 \mathrm{ft}$-grid intersection was a scintillation detector with a $25 \mathrm{~mm}$ thick $\mathrm{x} 25 \mathrm{~mm}$ dia. NaI(Tl) crystal and a rate meter readout. This type of instrument is commonly referred to as a micro $R$ meter and was calibrated to estimate the radiation exposure rate in micro roentgens per hour. All exposure-rate measurements were taken at approximately three feet aboveground. A plot of exposure-rate contours in the test area is shown in Fig. 7 .

TUBE SPACING - Based on the results of the aboveground radiation measurements, it was decided to zeduce the test area to $60 \mathrm{ft} \times 150 \mathrm{ft}$ and to place tubes on $10 \mathrm{ft} \times 10 \mathrm{ft}$ grids rather than $20 \mathrm{ft} \times 20 \mathrm{ft}$. Between November 27 and November 29, 1989, 118 tubes were driven in the test area. The tube locations are shown in Fig. 8. 


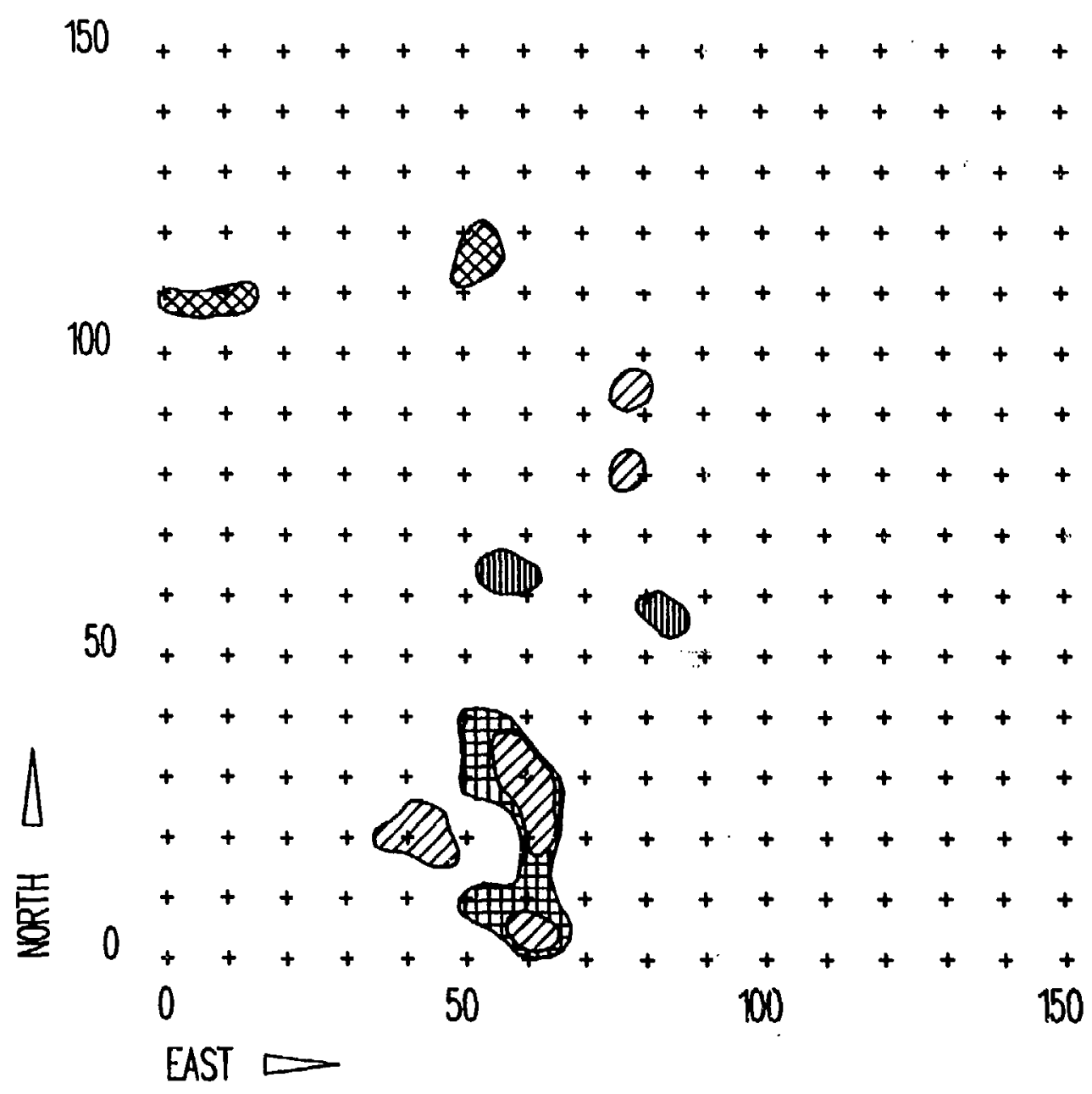

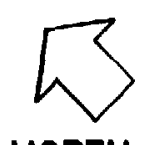

NORTH

+ GRID INTERSECTIONS CRID INTERSECT ION $=10 \mathrm{FT}$ SCALE 1:400

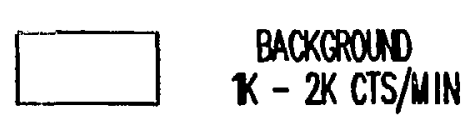

HK - 5K CTS/MIN
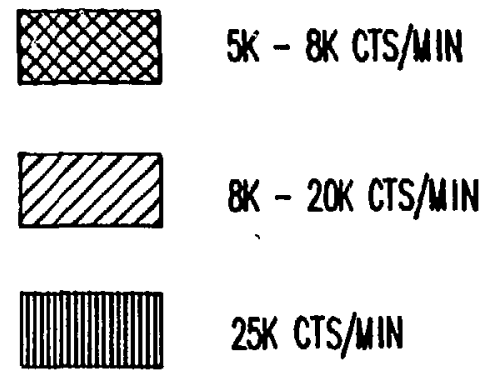

Figure 6. Radiation Relative Count Rates Detectable Aboveground (Few Inches from Surface). 

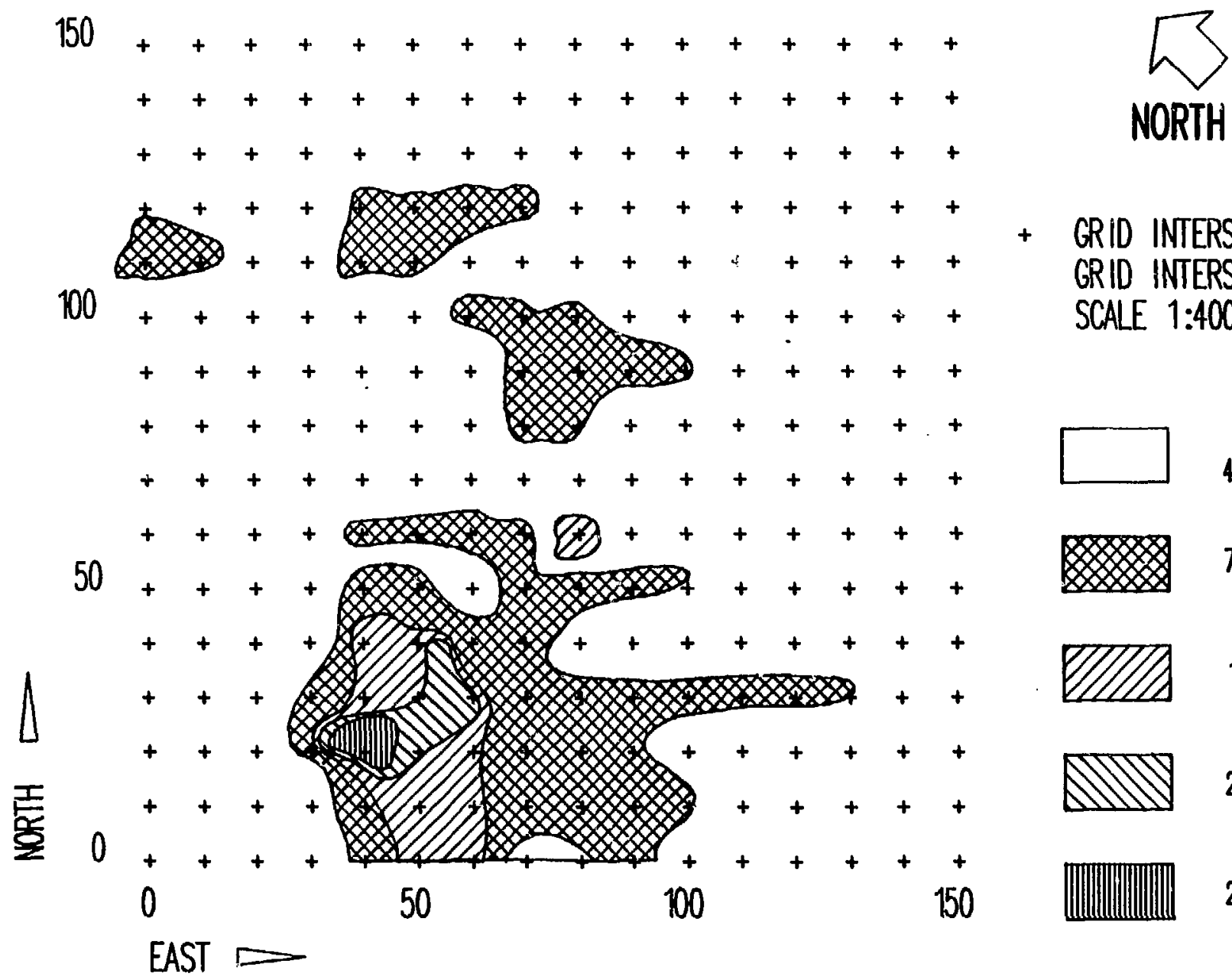

\section{NORTH}

+ GRID INTERSECTIONS

GRID INTERSECTION $=10 \mathrm{FT}$ SCALE 1:400

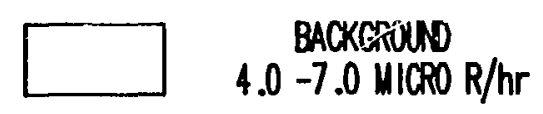

$7.0-12.0 \mathrm{NICKO} \mathrm{R} / \mathrm{hr}$

$15.0-20.0 \mathrm{MICPO} \mathrm{R} / \mathrm{hr}$

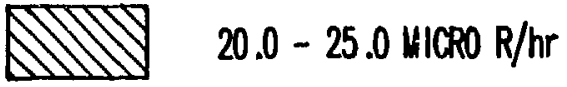

Figure 7. Radiation Exposure Rates at 3 ft Above Surface. 


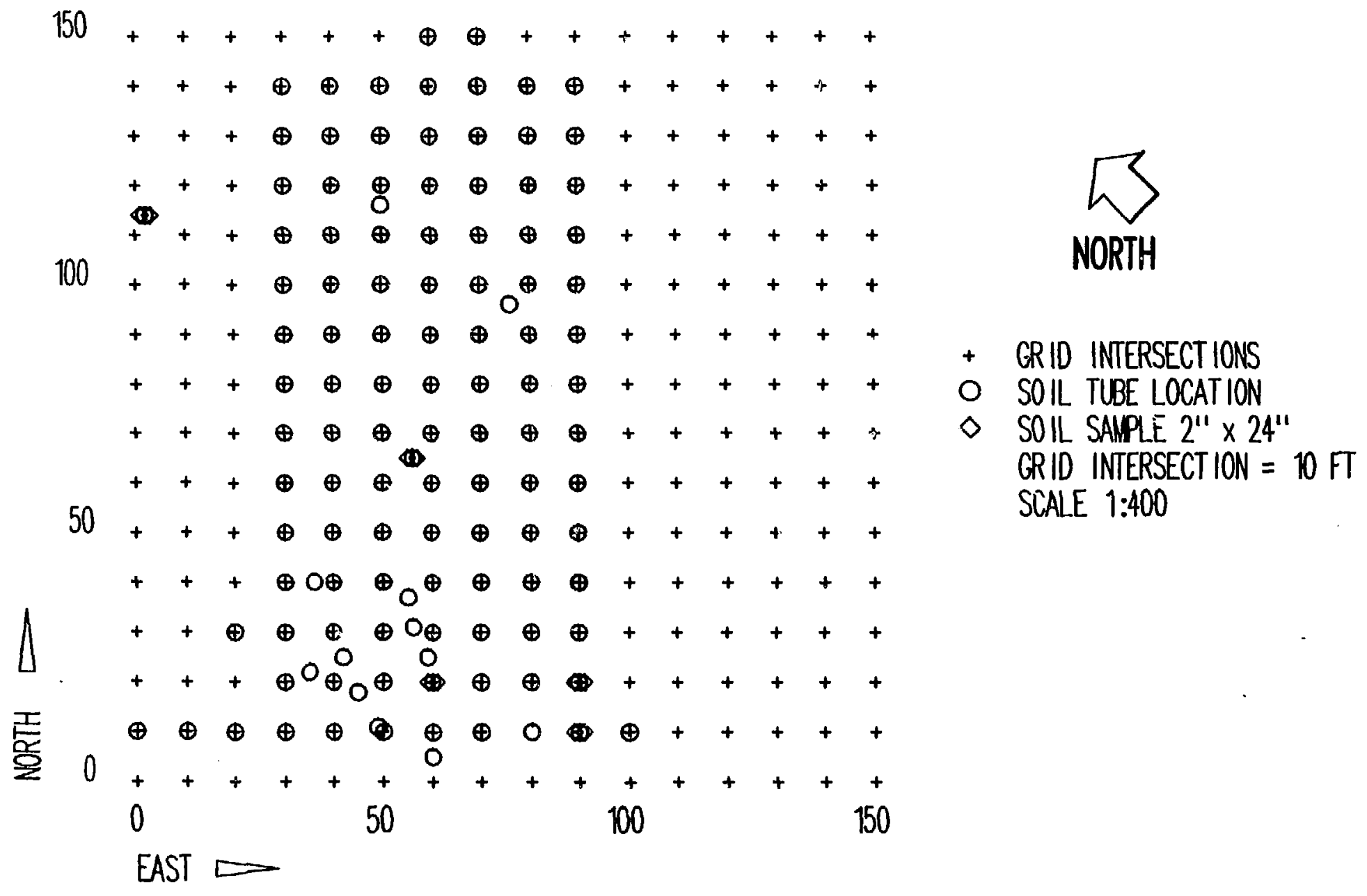

Figure 8. Locations of Driven Tubas and Soil Samples in Test Area. 


\section{CONTAMINATION-DEPTH-PROFILE DATA}

Contamination-depth-profile data were collected by lowering the $3 / 8$ in $x 3 / 8$ in $\mathrm{NaI}(\mathrm{T} \ell)$ detector into each driven tube and taking countrate readings at depth increments. Count-rate measurements were taken at $0.1 \mathrm{ft}$ increments for the first $0.5 \mathrm{ft}$ depth and at $0.5 \mathrm{ft}$ increments for all other depths. An example of the raw data is shown in Table 1 . The countsper-minute (cts/min) data vs. depth were graphed for each tube location. An example graph of the data is shown in Fig. 9. Graphs of data from all of the 118 tube locations are given in Appendix $B$.

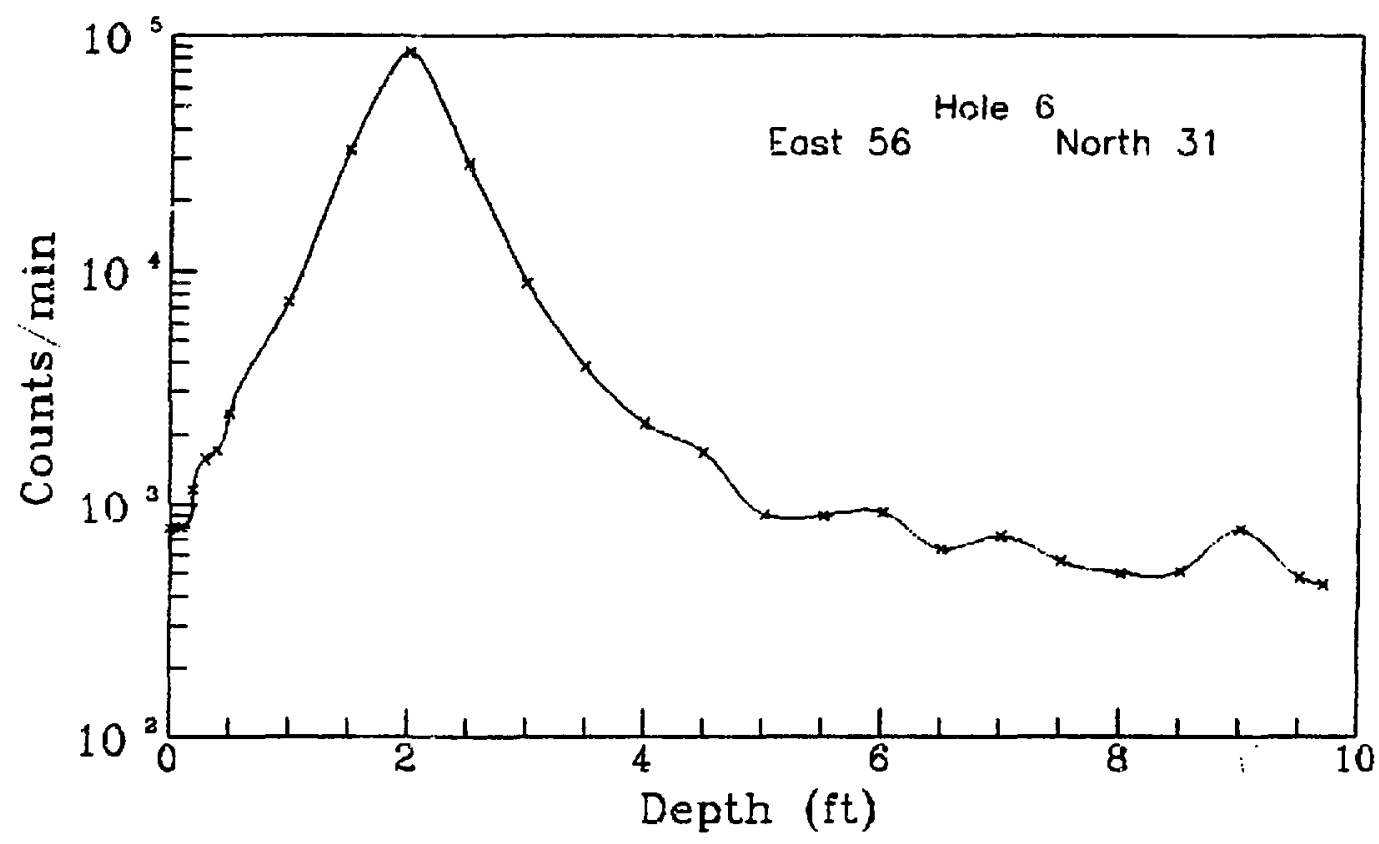

Figure 9. Example of Contamination-Depth Profile (Count Rate Vs. Depth). 
Table 1. Example of Contamination-Depth-Profile Data.

ARGONNE NATIONAL LABORATORY - BARROWS FIELD, GLEN RIDGE, N.J. DATE : $11 / 28 / 189$

PAGE : 6 _OF 118

SOIL TUBE NUMBER:

6

COORDINATES: $\mathrm{X}$ (E) 56 it

LUDLUM MODEL * 2220 221 SER. $\% 68519$ SOIL TUBE GAMMA LOG

BACKGROUND: 80 CTSTMI: SURVEYOR(S): M.J.Robiner: J.H. Vacea BGO NORMAL COUNTING TIME: 0.1 MIN

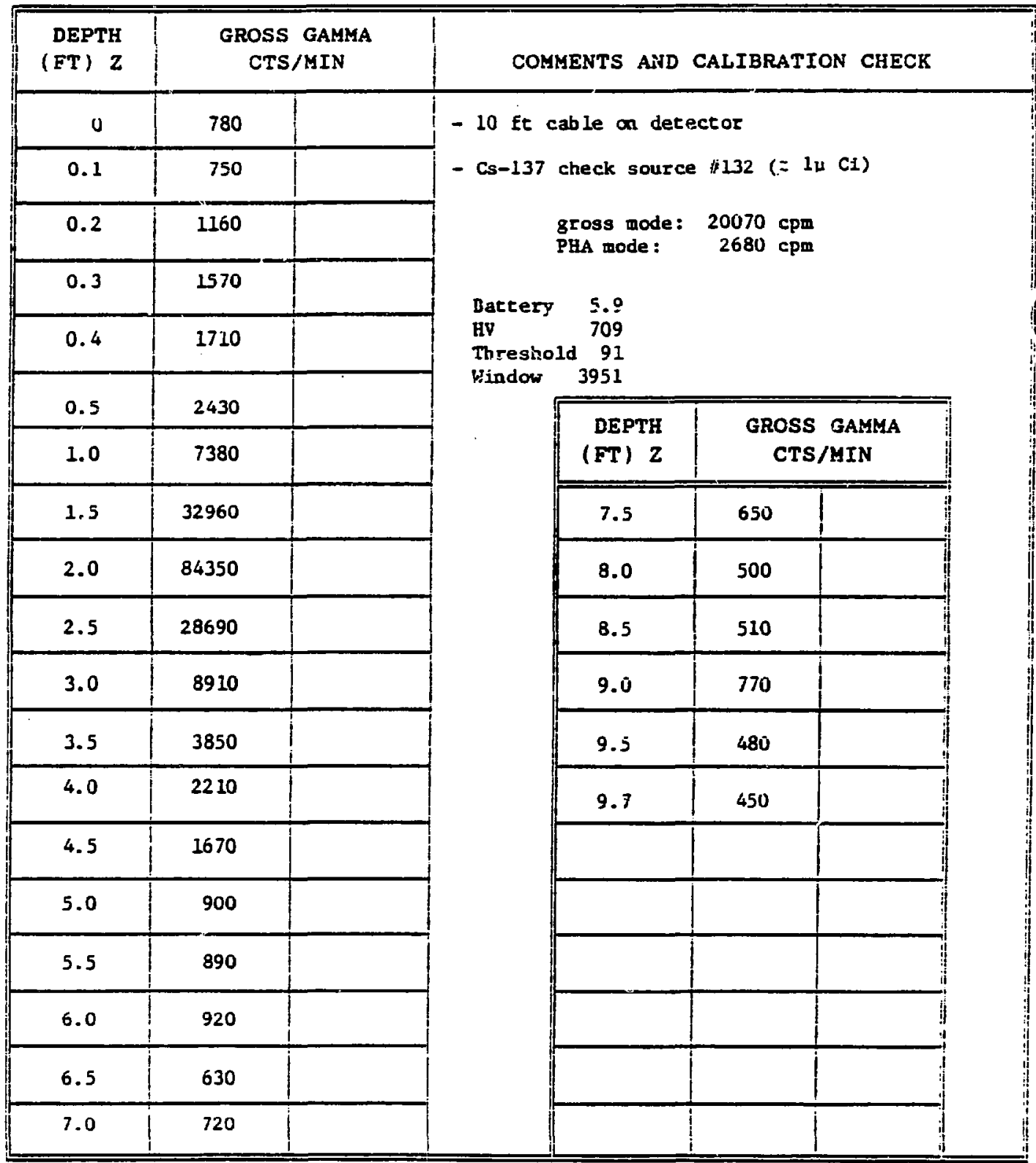




\section{CORRELATION OF COUNT RATE AND ACITVITY CONGENTRATION}

The depth-profile graphs, such as that in Figure 9, are interesting, but they can be used to determine depths to a specified concentration criterion only if there is a known correlation between count rates measured in the tubes and radium activity in the surrounding soil. That is, cts/min must be converted to $\mathrm{pCi}-2{ }^{\circ} \mathrm{Ra} / \mathrm{g}$. A count-rate-to-activity concentration was determined for specific detectors prior to this project by taking soil samples around the locations where counc-rate measurements were taken in tubes. The concentration of radium in the soil samples was measured with a laboratory gamma-ray spectrometer. The correlation for count rates from the $3 / 8$ in $x 3 / 8$ in detector used in Barrows Fleld Park is given by the following straight-line equation:

$$
R=128 C+160 \quad \text { Equation No. } 1
$$

where $R=$ count rate in cts/min when using a $3 / 8$ in $x 3 / 8$ in $\operatorname{NaI}$ (T $\ell$ ) detector "system" which was calibrated to read approximately $2 \times 10^{4} \mathrm{cts} / \mathrm{min}-\mu \mathrm{Ci}$ of $1 \mathrm{~g}^{7} \mathrm{Cs}$ at the detector surface (1-in-dia. disk source).

C - Average (equivalent to homogeneous) ${ }^{226} \mathrm{Ra}$ concentration in $\mathrm{pCi} / \mathrm{g}$ of soil.

Ten soil samples were collected at five tube locations in the test area to compare the count rates and activity concentrations to that predicted by Equation 1. The samples were collected (at about one foot away from the EMT tubes) with 2 in-dia. Shelby tubes and the radium concentrations in the samples were measured at ANL with a gamma-ray spectrometer. Ths radium concentration in the soil samples and the corresponding count rates measured in the EMT tubes at the sampled depths are shown in Table 2. The sample numbers indicate the tube location from which the sample was collected. The $N$ added to the tube number indicates that the sample was taken about one foot north of the tube. Likewise, the $S$ indicates that the sample was taken about one foot south of the tube. 
Table 2. Radium Concentration in Soil Samples from Test Area in Barrows Field Park.

\begin{tabular}{|c|c|c|c|c|c|c|c|c|c|}
\hline Tube Ho. & $\begin{array}{c}\text { Coordinate } \\
\text { E,N } \\
\text { (Feet) }\end{array}$ & $\begin{array}{l}\text { Count Rate } \\
\text { in EMI Tube } \\
\text { ot Sampl.ed } \\
\text { Depth } \\
\text { (Cts/Min) }\end{array}$ & $\begin{array}{l}\text { Shelby } \\
\text { tubes } \\
\text { Serple } \\
\text { No. }\end{array}$ & $\begin{array}{l}\text { Sample } \\
\text { Depth } \\
\text { (feet) }\end{array}$ & $\begin{array}{c}\text { Ra-226( } 186 \mathrm{keV}) \\
\mathrm{pCl} / \mathrm{g} \pm 1\end{array}$ & $\begin{array}{c}\mathrm{Pb}-214(1,25 \mathrm{key}) \\
\mathrm{PCl} / \mathrm{g} \pm 1\end{array}$ & $\begin{array}{c}81-214(609 \mathrm{keV}) * \\
\mathrm{pCl} ;=\leq 1\end{array}$ & $\begin{array}{c}\text { Ac-228 (919 kev) } \\
\mathrm{pcl} / \mathrm{a} \pm 1\end{array}$ & $\begin{array}{c}k-40(1460 \mathrm{keV}) \\
\mathrm{pcl} / \mathrm{g} \pm 1\end{array}$ \\
\hline 9 & 56,65 & 90000 & $\begin{array}{l}9 \mathrm{~N} \\
9 \mathrm{~S}\end{array}$ & $\begin{array}{l}0.5-1.0 \\
0.5-1.0\end{array}$ & $\begin{array}{r}101.0 \pm 1.1 \\
57.6 \pm 1.0\end{array}$ & $\begin{array}{l}92.0 \pm 0.2 \\
53.6 \pm 0.2\end{array}$ & $\begin{array}{l}76.1 \pm 0.2 \\
44.4 \pm 0.2\end{array}$ & $\begin{array}{l}0.8 \pm 0.2 \\
0.8 \pm 0.2\end{array}$ & $\begin{array}{l}8.0 \pm 0.8 \\
6.6 \pm 0.7\end{array}$ \\
\hline 12 & 2. 114 & $740-1000$ & $\begin{array}{l}12 \mathrm{~N} \\
125\end{array}$ & $\begin{array}{l}0.5-1.0 \\
0.5 \cdot 1.0\end{array}$ & $\begin{array}{l}3.4 \pm 0.3 \\
3.6 \pm 0.3\end{array}$ & $\begin{array}{l}2.8 \pm 0.1 \\
2.0 \pm 0.1\end{array}$ & $\begin{array}{l}3.4 \pm 0.1 \\
1.7 \pm 0.1\end{array}$ & $\begin{array}{l}0.8 \pm 0.1 \\
0.6 \pm 0.1\end{array}$ & $\begin{array}{l}7.5 \pm 0.4 \\
8.0 \pm 0.4\end{array}$ \\
\hline 22 & 90,10 & $550 \cdot 600$ & $\begin{array}{l}22 \mathrm{H} \\
225\end{array}$ & $\begin{array}{l}1.5 \cdot 2.0 \\
1.5 \cdot 2.0\end{array}$ & $\begin{array}{l}4.7 \pm 0.3 \\
4.8 \pm 0.3\end{array}$ & $\begin{array}{l}2.1 \pm 0.1 \\
1.9 \pm 0.1\end{array}$ & $\begin{array}{l}1.9 \pm 0.1 \\
1.9 \pm 0.1\end{array}$ & $\begin{array}{l}2.1 \pm 0.1 \\
2.2 \pm 0.1\end{array}$ & $\begin{array}{l}7.6 \pm 0.4 \\
6.0 \pm 0.4\end{array}$ \\
\hline 27 & 60,20 & $1200-1300$ & $\begin{array}{l}27 \mathrm{~N} \\
27 \mathrm{~S}\end{array}$ & $\begin{array}{l}0.5 \cdot 1.0 \\
0.5 \cdot 1.0\end{array}$ & $\begin{array}{r}16.5 \pm 0.5 \\
9.1 \pm 0.4\end{array}$ & $\begin{array}{r}12.4 \pm 0.1 \\
6.2 \pm 0.1\end{array}$ & $\begin{array}{r}10.7 \pm 0.1 \\
5.3 \pm 0.1\end{array}$ & $\begin{array}{l}0.6 \pm 0.1 \\
0.8 \pm 0.1\end{array}$ & $\begin{array}{l}7.7 \pm 0.5 \\
9.5 \pm 0.5\end{array}$ \\
\hline 30 & 90,20 & $360-460$ & $\begin{array}{l}30 \mathrm{~N} \\
30 \mathrm{~S}\end{array}$ & $\begin{array}{l}1.0 \cdot 2.0 \\
1.0 \cdot 2.0\end{array}$ & $\begin{array}{l}3.2 \pm 0.2 \\
3.5 \pm 0.2\end{array}$ & $\begin{array}{l}1.9 \pm 0.1 \\
1.7 \pm 0.1\end{array}$ & $\begin{array}{l}2.0 \pm 0.1 \\
1.6 \pm 0.1\end{array}$ & $\begin{array}{l}1,8 \pm 0.1 \\
1.9 \pm 0.1\end{array}$ & $\begin{array}{l}6.9 \pm 0.2 \\
6.7 \pm 0.2\end{array}$ \\
\hline
\end{tabular}

* The concentrations of Bi-214 were used in Figure 10 (Comparison of Eouation 1 to Soil Sanple Data from Test Area) as a measure of the radium concentration rather than Ra-226 itself because the 609-keV photons from Bi-214 are the predominant photons from radium and its daughter products. It is primarily the 609-keV photons from Bi-214 that are cetected in the ENI tubes. The 186-keV photons emitted by Ra-226 contríbute little to the measured count rate in the EMT because of self-absorption in the soll and attenuation in the wall of the EMr and in the protective cover on the detector. 
A comparison of the data and the plot of Equation 1 is shown in Fig. 10 . Because there is a range of values for the count rates and for the radium concentrations, the daca "points" are shown as rectangles. The vertical height of a rectangle is the count-rate range measured in the EMT tube, and the horizontal length of a rectangle is the $\mathrm{pCi} / \mathrm{g}$ range in the soil samples. The uncertainty (the error bars) for individual measurements are insignificant compared to the range of values at a given location. Two of the data rectangles (tube 12 and tube 22) do not intercept the predicted line from Equation 1. This is interpreted to mean that the samples did not catch the

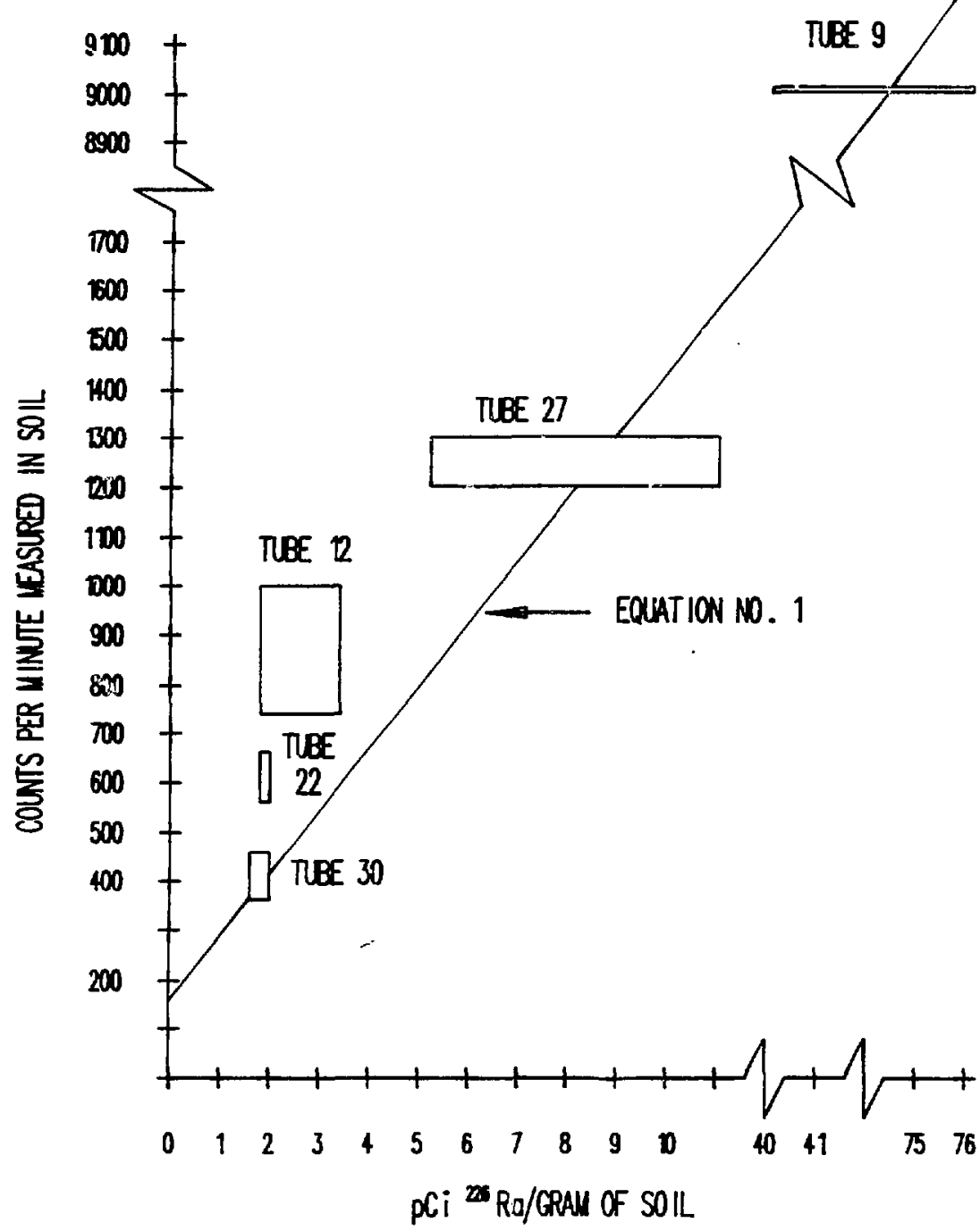

Figure 10. Comparison of Equation 1 to Soil-Sample Data from Test Area. 
full range of concentrations around those tubes. Additional samples around those tube locations would be expected to show higher radium concentrations. Overall, the limited data are considered to be consistent with the correlation provided by Equation 1. Therefore, Equation 1 was used to make all conversions from count rate to $\mathrm{pCi} / \mathrm{g}$. Fig. 11 is a graph of Fig. 9 replotted in terms of $\mathrm{pCi} / \mathrm{g}$ rather than count rate.

The concentration of naturally occurring ${ }^{10} \mathrm{~K}$ is included in Table 2 to determine whether or not there were large variations in ${ }^{40} \mathrm{~K}$. Very high concentrations in $10 \mathrm{~K}$ could be misinterpreted as radium contamination. However, the small $\mathrm{NaI}(\mathrm{Tl})$ detector used in the tubes is less sensitive to the $1460 \mathrm{keV}$ photon from ${ }^{\circ}{ }^{\circ} \mathrm{K}$ than to the lower energy photons from radium and its daughters. Therefore, small variations in ${ }^{\circ} \mathrm{K}$ do not affect the validity of the correlation between count rates measured in the tubes and radium concentration. The Berrows Field Park ${ }^{10} \mathrm{~K}$ concentrations are within the lower range of values typically found in other areas of the country (NCRP-87).

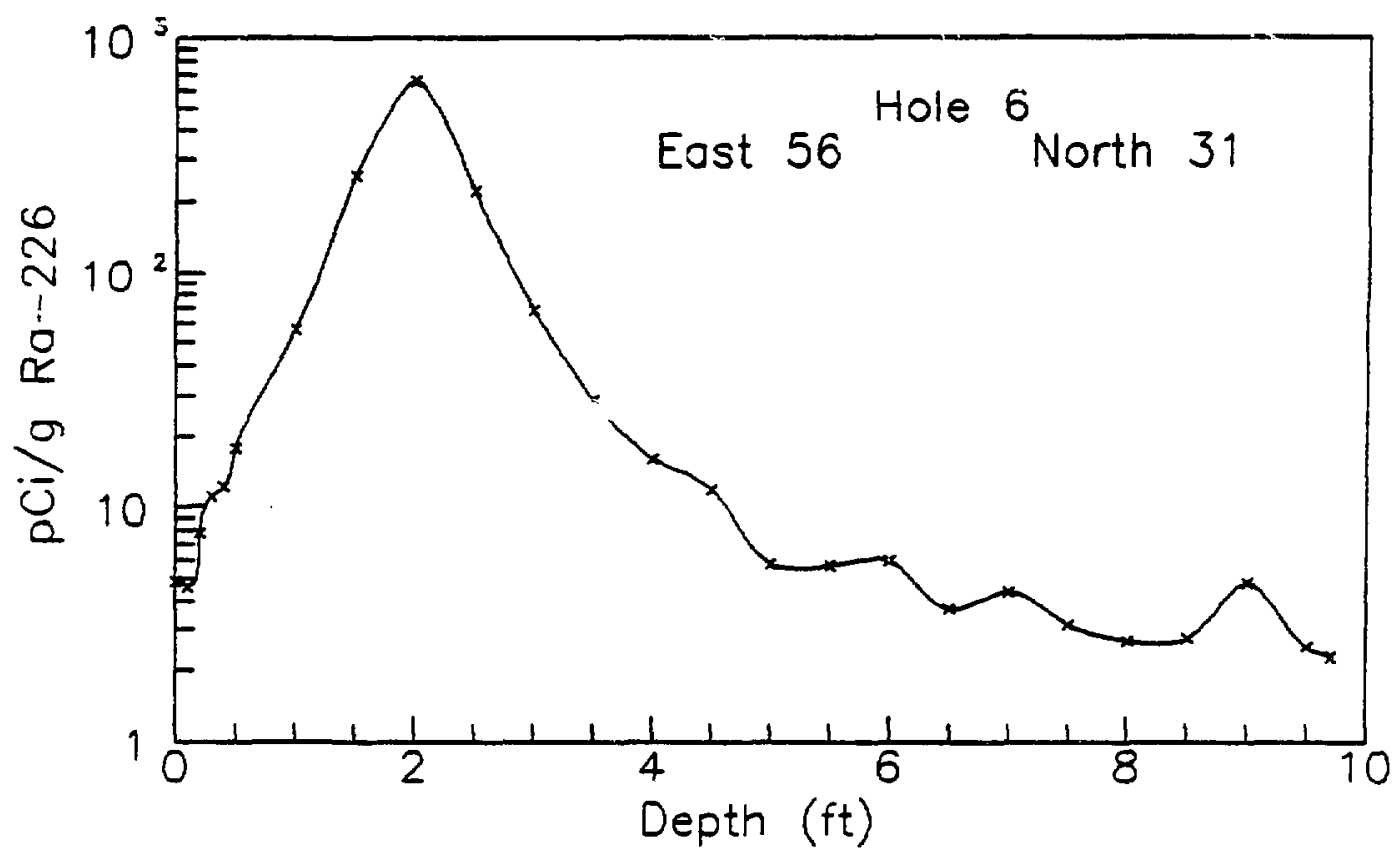

Figure 11. Example of Contamination-Depth Profile (pCi/g Vs. Depth). 


\section{DEPTHS TO CRITERIA}

Using Equation 1 , the cleanup criterion of $5 \mathrm{pCi} 226 \mathrm{Ra} / \mathrm{g}$ corresponds to $800 \mathrm{cts} / \mathrm{min}$ and $15 \mathrm{pCi}{ }^{22}{ }^{6} \mathrm{Ra} / \mathrm{g}$ corresponds to approximately $20 \mathrm{co} \mathrm{cts} /$ min (with the $3 / 8$ in $\times 3 / 8$ in $\mathrm{NaI}$ detector system). These count rates are used with the contamination-depth-profile plots to determine the depths where the concentration drops below the criteria of 5 and $15 \mathrm{pCi} / \mathrm{g}$. For. example, in Fig. 12 the concentration drops to $5 \mathrm{pCi} / \mathrm{g}$ at $10 \mathrm{ft}$ and it drops to $15 \mathrm{pCi} / \mathrm{g}$ at a depth of about $6.8 \mathrm{ft}$.

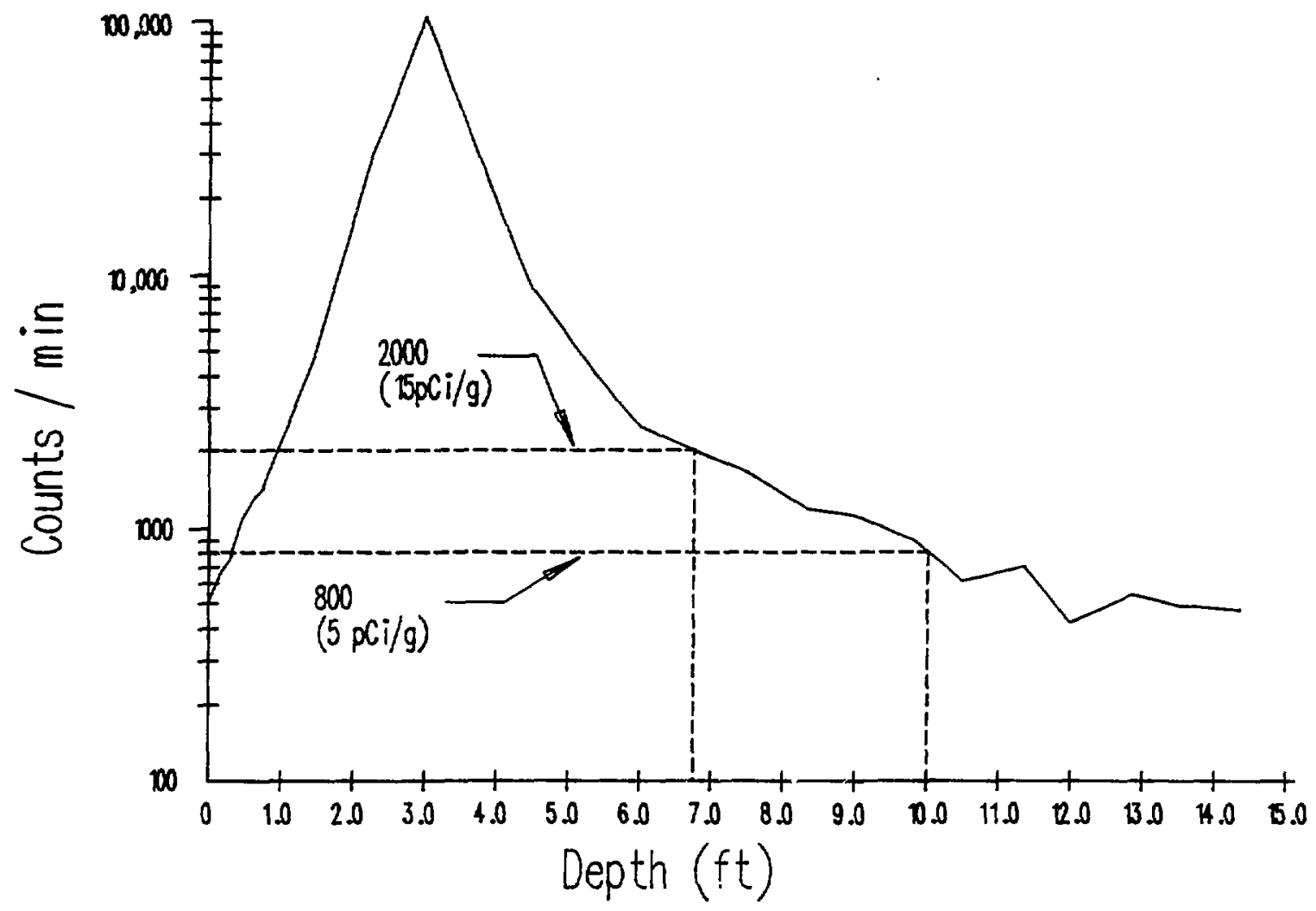

Figure 12. Determination of Depth-to-Concentration Criteria. 
The contamination-depth-profile plots in Appendix B were used to determine the depths to $5 \mathrm{pCi} / \mathrm{g}$ and to $15 \mathrm{pCi} / \mathrm{g}$ at each tube location. These depths were then plotted at their coordinates and similar depths ware grouped into contours. Contours of depths to $5 \mathrm{pCi} / \mathrm{g}$ are shown in Fig. 13 . Contours of depths to $15 \mathrm{pCi} / \mathrm{g}$ are shown in Fig. 14 .

In addition to the depth to 5 and $15 \mathrm{pCi} / \mathrm{g}$, the depths to the layer of soil with concentrations greater than $200 \mathrm{pCi} / \mathrm{g}$ are of special interest because the proposed soil-decontamination test has been optimized for concentrations less than $200 \mathrm{pCi} / \mathrm{g}$. The depths to any layer of contamination and the thickness of the layer can be easily determined from the contaminationdepth-profile plots. As in the previous examples, Equation 1 is used to convert cts/min to radium concentration in soil. Therefore, a concentr ${ }^{-i}$.on of 200. $\mathrm{pCi} / \mathrm{g}$ corresponds to approximately $26,000 \mathrm{cts} / \mathrm{min}$. minute. Using the depth-profile plot in Fig. 15 as an example, a horizontal line at 26,000 cts/ min intercepts the rising part of the depth-profile curve at the deptr: $Z_{1}$, and the falling part of the curve at the depth $Z_{2}$. The depth $Z_{1}$ (about $2.2 \mathrm{ft}$ for this example) is the depth to the top of the $200 \mathrm{pCi} / \mathrm{g}$ layer of soil. Stated more precisely, it is the depth to the top of the layer of soll where the concentration is equal to or greater than $200 \mathrm{pCi} / \mathrm{g}$. Likewise, the depth $\mathrm{Z}_{2}$ (about $3.8 \mathrm{ft}$ ) is the depth to the bottom of the $\geq 200 \mathrm{pCi} / \mathrm{g}$ layer. The difference between the depths $\mathrm{Z}_{2}$ and $Z_{1}$ is the thickness of the $\geq 200 \mathrm{pCi} / \mathrm{g}$ layer. For this example, the layer is about $1.6 \mathrm{ft}$ thisk.

Figure 16 shows the same kind of analysis for the $\geq 300 \mathrm{pCi} / \mathrm{g}$ layer.

Contours of the depths to the top and bottom of the $\geq 200 \mathrm{pCi} / \mathrm{g}$ layer are shown in Figs. 17 and 18, respectively. The small icon of a depth-profile curve in the lower right hand portion of each figure is provided to further illustrate how the data were obtained. Contours of the thickness of the $\geq 200 \mathrm{pCi} / \mathrm{g}$ layer are shown in Fig. 19 . 

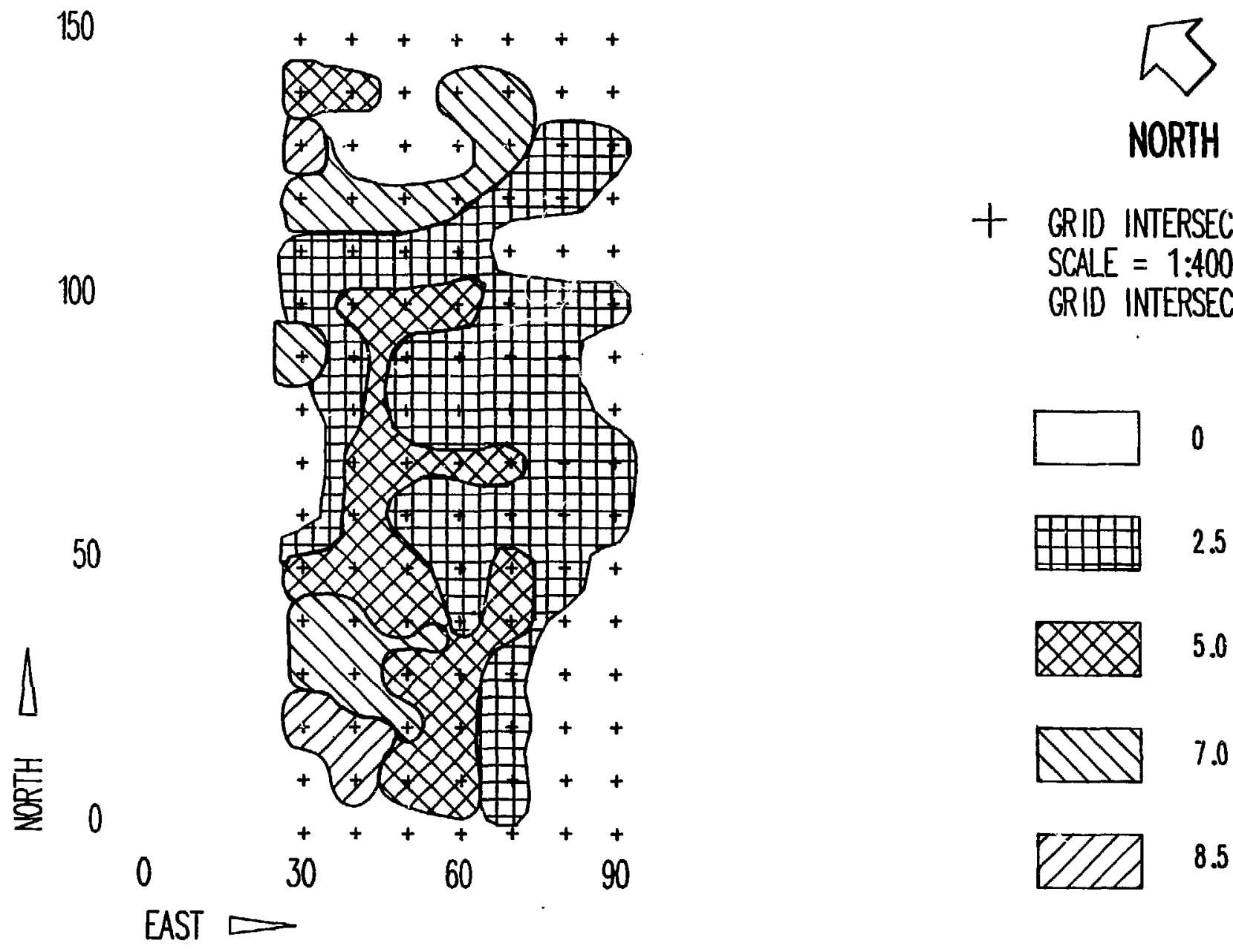

+ GRID INTERSECTIONS SCALE = 1:400 GRID INTERSECTION $=10 \mathrm{FT}$.

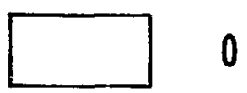

2.5-4.5

$5.0-6.5 \mathrm{~T}$

III $7.0-8.0 \mathrm{~F}$

EID $8.5-11.0 \mathrm{~F}$

Firure 13. Depths to $5 \mathrm{pci}{ }^{226} \mathrm{Ra} / \mathrm{gram}$. 


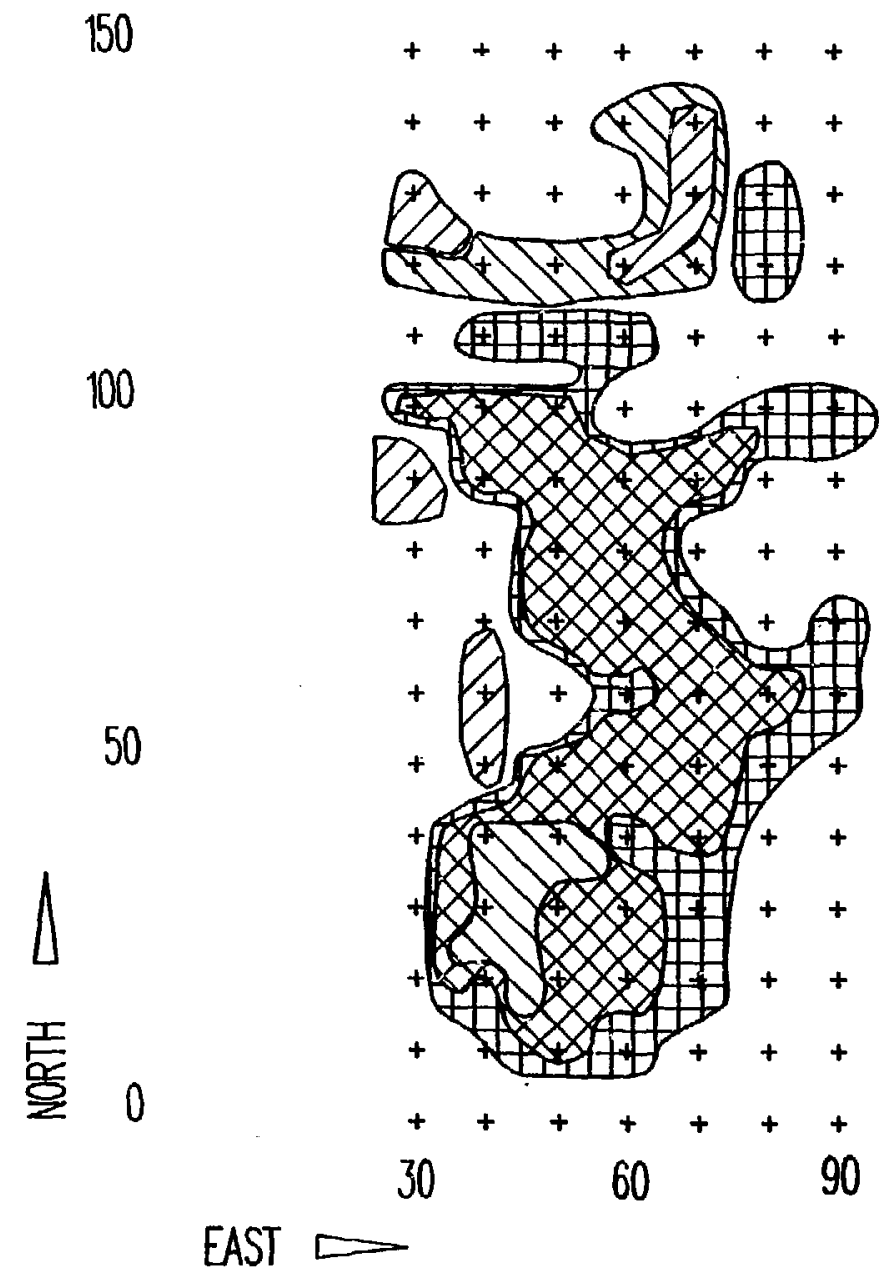

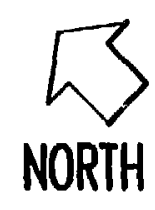

+ GRID INTERSECTIONS SCALE $=1: 400$ GRID INTERSECTION $=10 \mathrm{FT}$

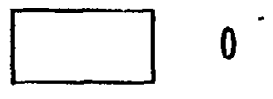

睓曲 $2.5-3.0 \mathrm{TT}$
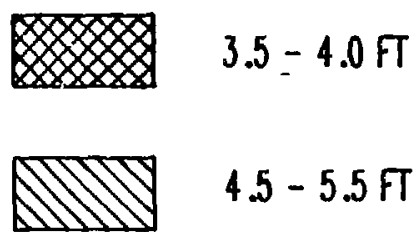

VIIIA $\quad 6.0-8.0 \mathrm{Ft}$

Figure 14. Depths to $15 \mathrm{pCi}{ }^{226} \mathrm{Ra} / \mathrm{gram}$. 


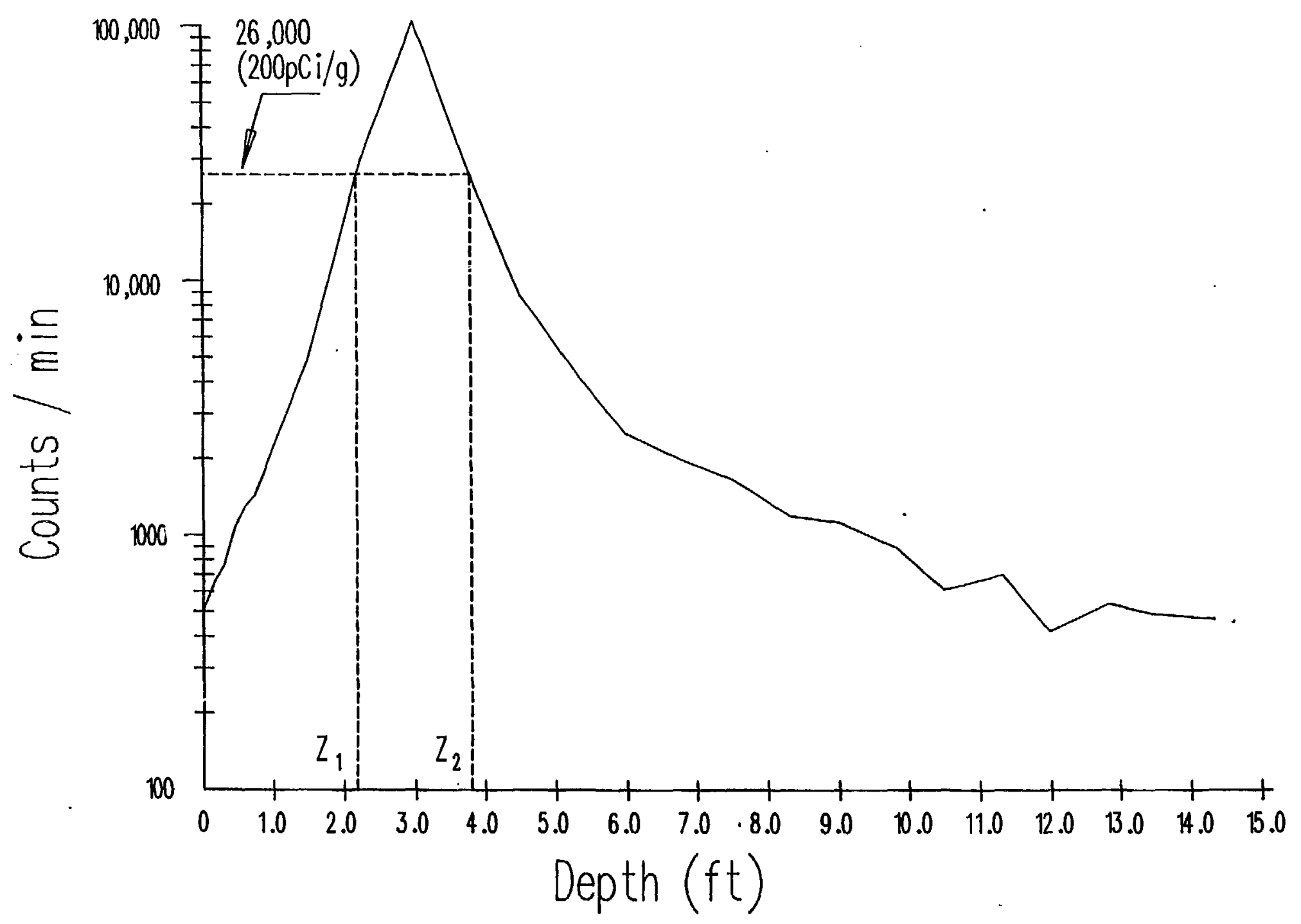

$N$

Figure 15. Determination of Depths to Top and Bottom of $\geq 200 \mathrm{pci} / \mathrm{gram}$ Layer of Soil. 


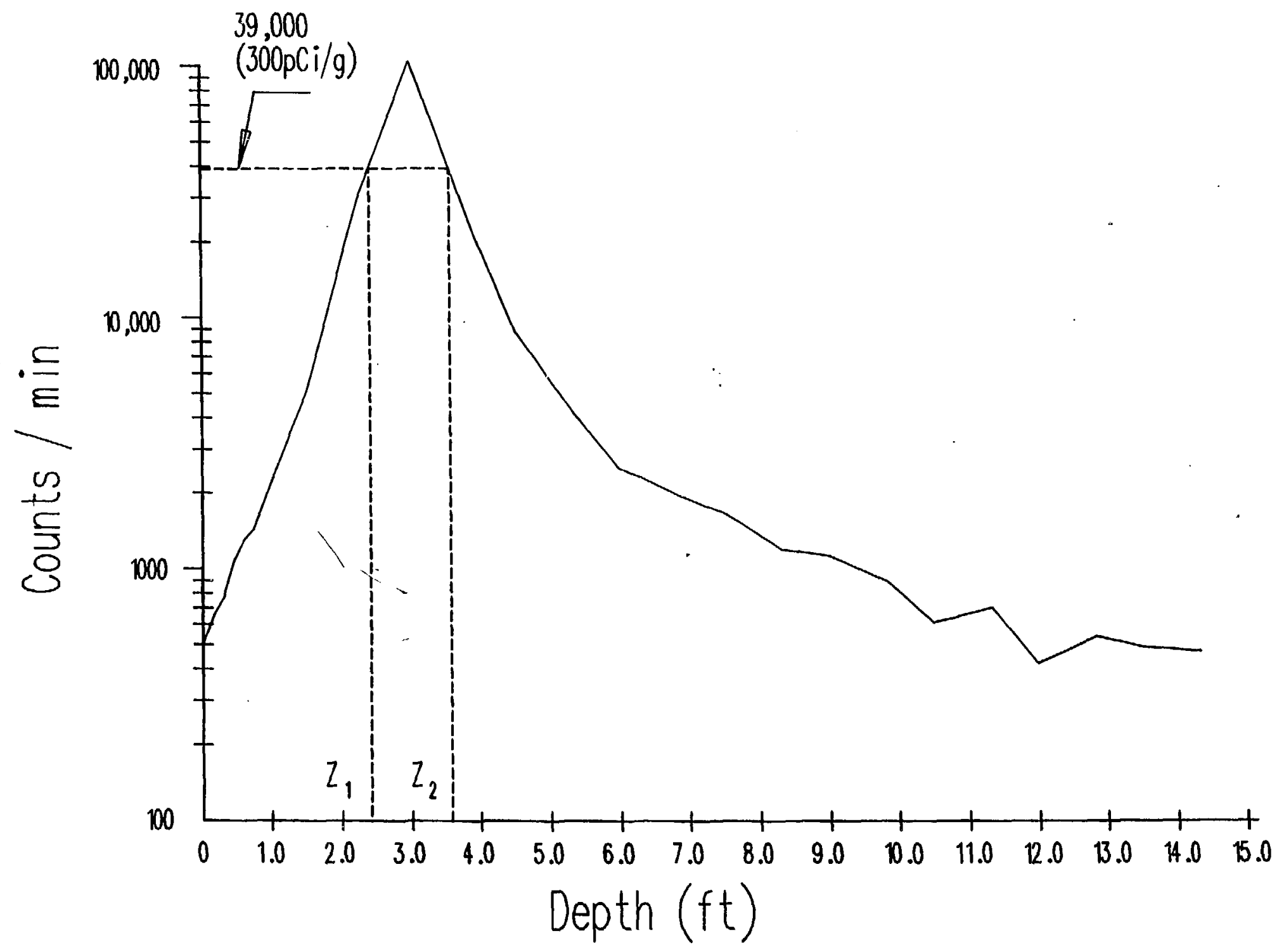

Figure 16. Determination of Depths to Top and Bottom of $\geq 300 \mathrm{pci} / \mathrm{gram}$ Layer of soll. 


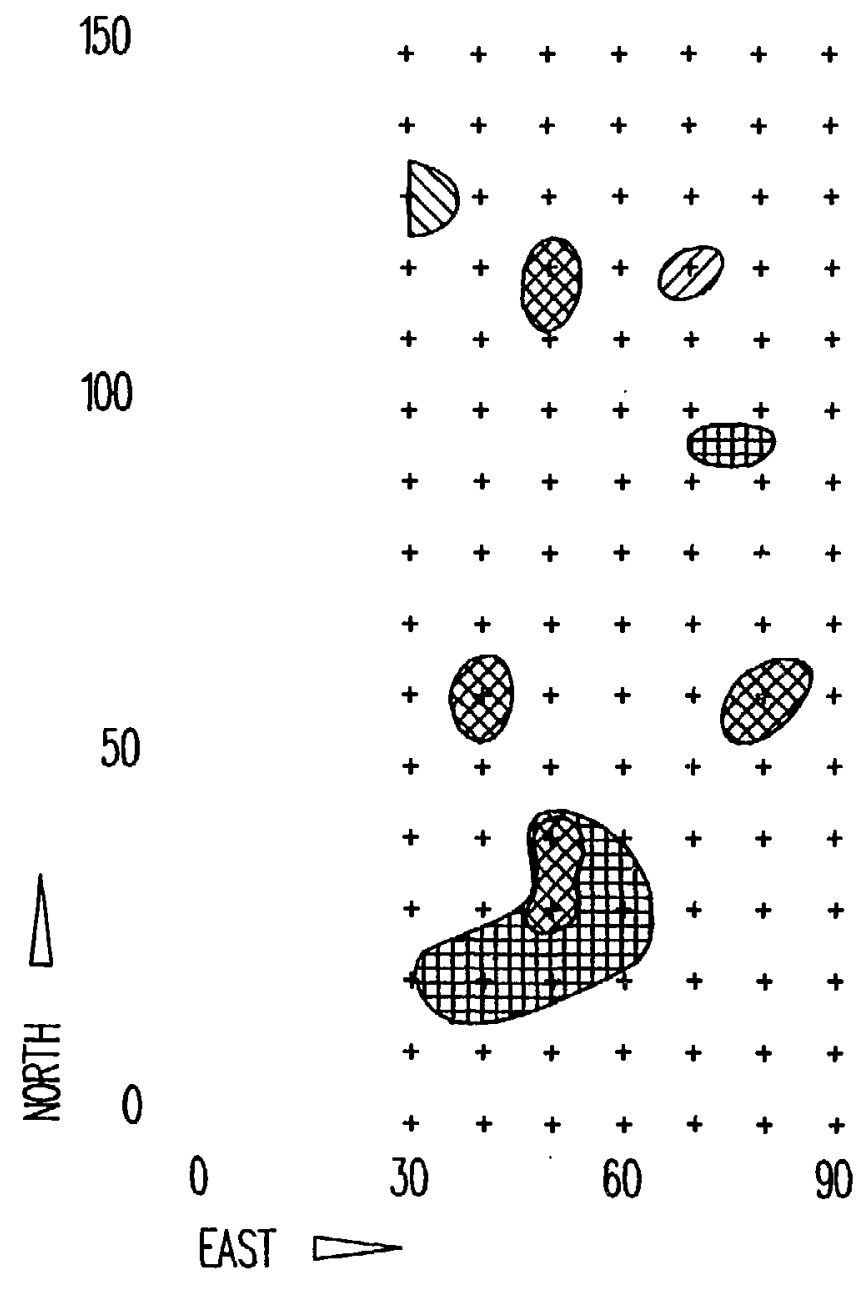

$B$

NORTH

+ GRID INTERSECTIONS

GRID INTERSECT ION $=10 \mathrm{FT}$ SCALE 1:400
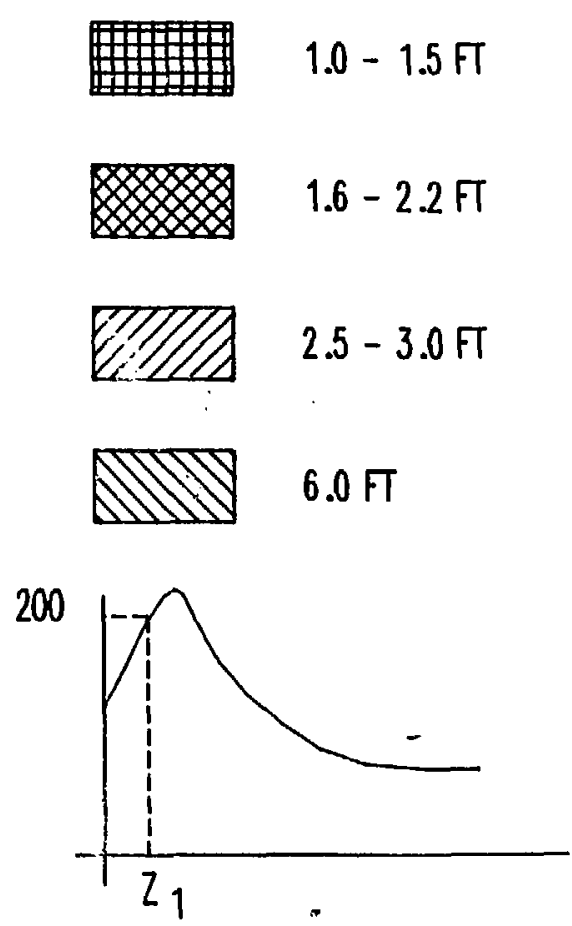

Figure 17. Depths to Top of $\geq 200 \mathrm{pci} / \mathrm{gram}$ Layer. 


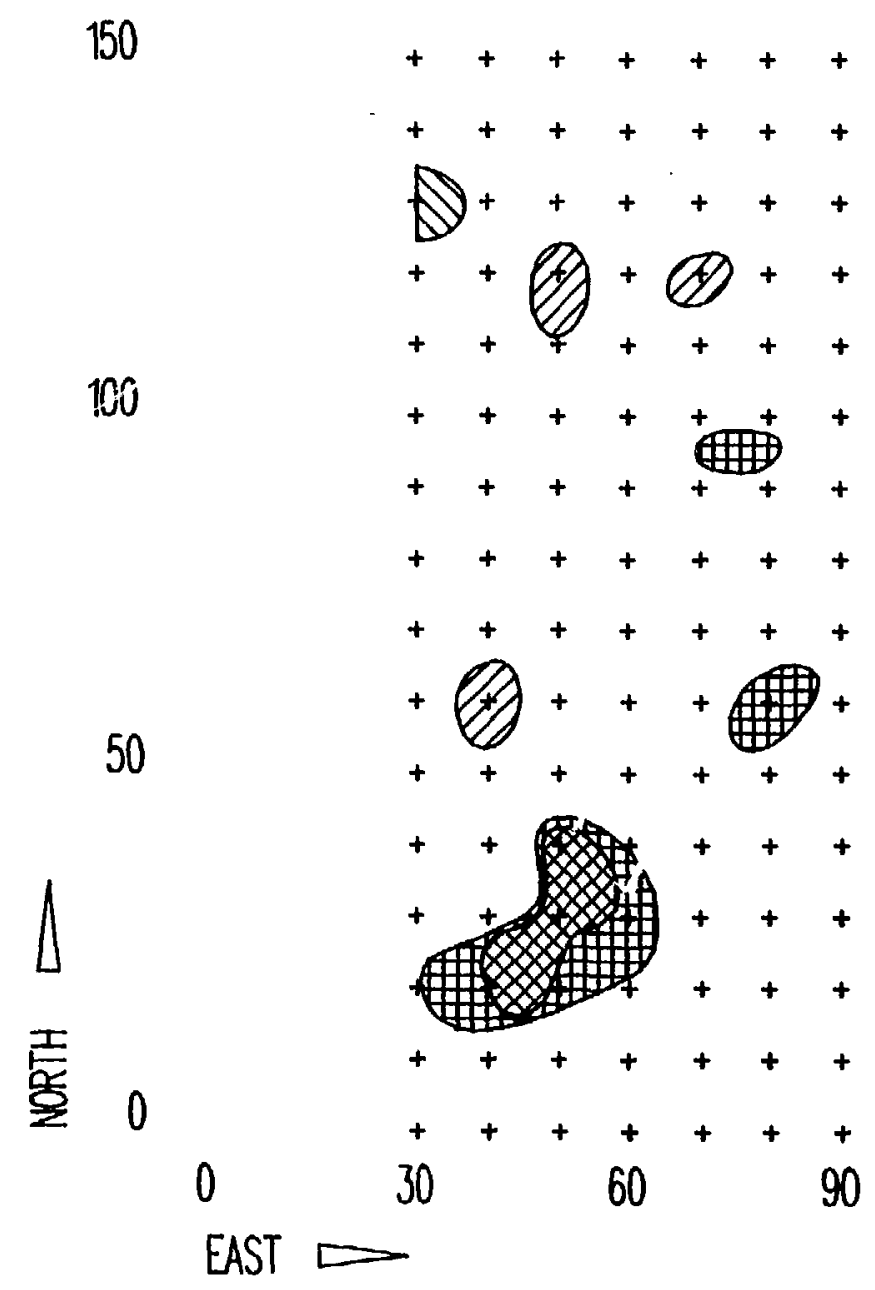

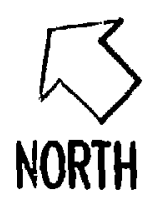

+ GRID INTERSECT!ONS GRID INTERSECTION $=10 \mathrm{FT}$ SCALE 1:400
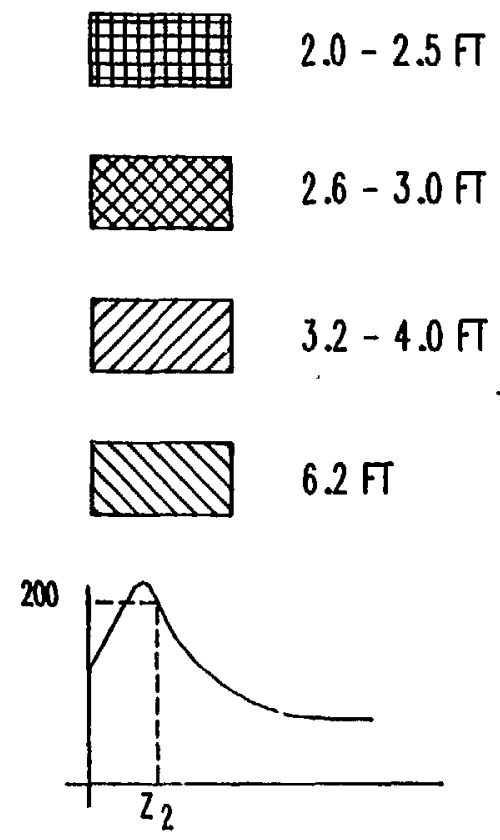

Figure 18. Depths to Bottom of $\geq 200 \mathrm{pc1} / \mathrm{gram}$ Layer. 


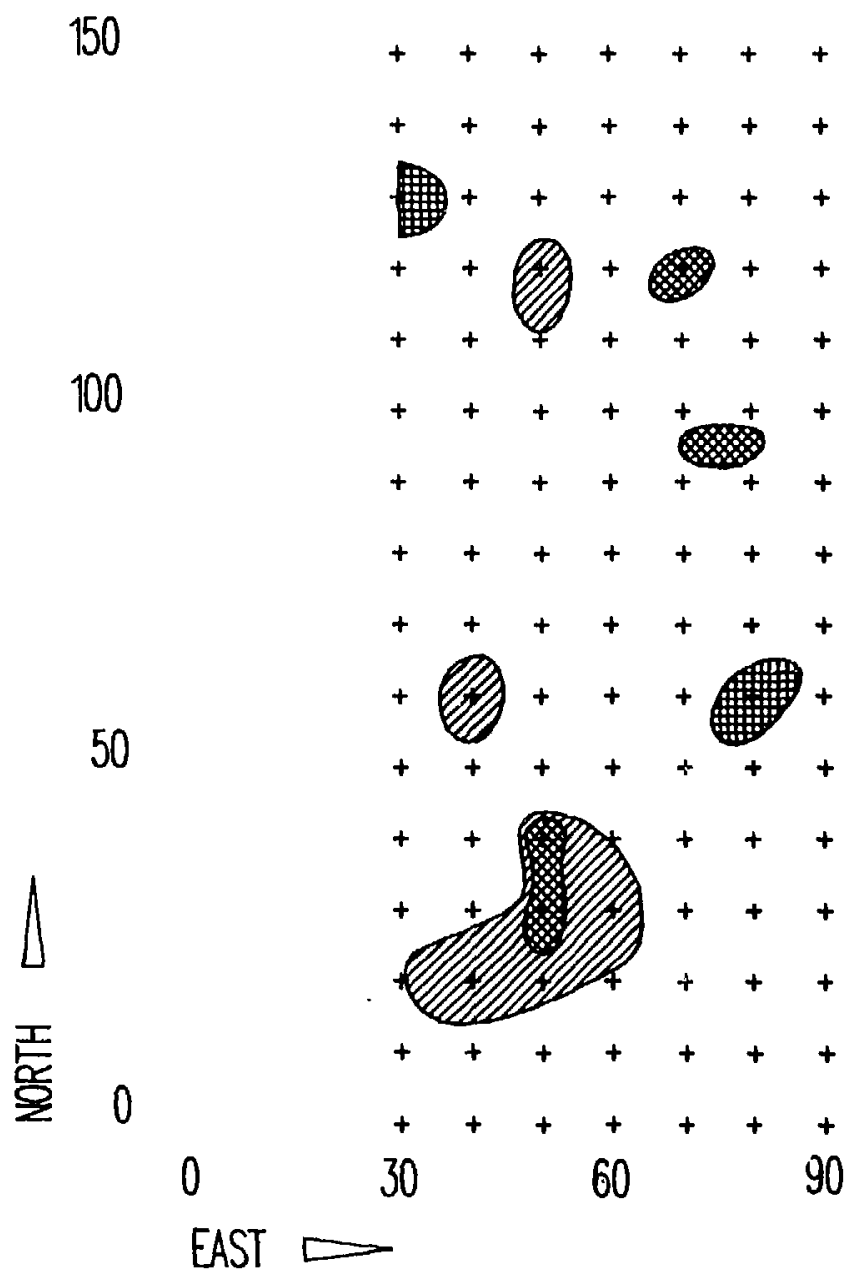

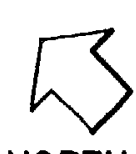

NORTH

+ GRID INTERSECTIONS GR DD INTERSECTION $=10 \mathrm{FT}$ SCALE 1:400

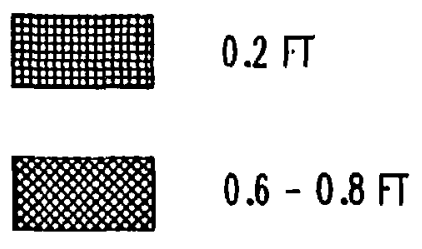

$1.0-1.8 F$

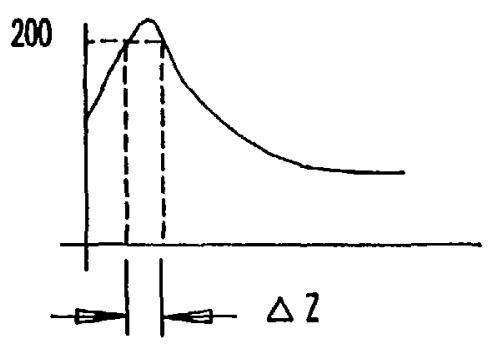

Figure 19. Thickness of $\geq 200 \mathrm{pci} / \mathrm{gram}$ Layer. 
Contours of the depths to the top and bottom of the $\geq 300 \mathrm{pCi} / \mathrm{g}$ layer are shown in Figs. 20 and 21, respectively. Contours of the thickness of the $\geq 300 \mathrm{pCi} / \mathrm{g}$ layer are shown in Fig. 22 .

A compaisisn of the contours of the thickness of the $\geq 200 \mathrm{pCi} / \mathrm{g}$ layer (Fig. 19) and the contours of the thickness of the $\geq 300 \mathrm{pCi} / \mathrm{g}$ layer (Fig. 22) mey be initially confusing because the figures show a minimum thickness of $0.2 \mathrm{ft}$ for the $\geq 200 \mathrm{pCi} / \mathrm{g}$ layer and a minimum thickness of 0.4-0.9 ft for the $\geq 300 \mathrm{pCi} / \mathrm{g}$ layer.

The depth profile curves (Figs. 15 and 16) show that it is impossible for the thickness of the $\geq 300 \mathrm{pCi} / \mathrm{g}$ layer to be greater than the thickness of the $\geq 200 \mathrm{pCi} / \mathrm{g}$ layer in the same location. In Figs. 19 and 22, the minimum thicknesses for the $\geq 200 \mathrm{pCi} / \mathrm{g}$ and the $\geq 300 \mathrm{pCi} / \mathrm{g}$ contours are in different locations. For example, there is no $\geq 300 \mathrm{pCi} / \mathrm{g}$ layer where the $\geq 200 \mathrm{pCi} / \mathrm{g}$ layer is only $0.2 \mathrm{ft}$ thick.

The contamination-depth-profile plots in Appendix B show that (except in areas where there was no contamination) the count rate increased with depth, reached a maximum value (in a few cases there are more than one maxima), and then decreased. This is a very common profile, but it is not universal. There are profiles in which the contamingeion is a maximun at the surface. The Barrows Field Park data probably indicate that the convamination was covered with clean soil or that some of the contamination is slowly moving downward. The maximum concentration and the depth at which it occurs for each tube location is listed in Table Cl of Appendix C. 


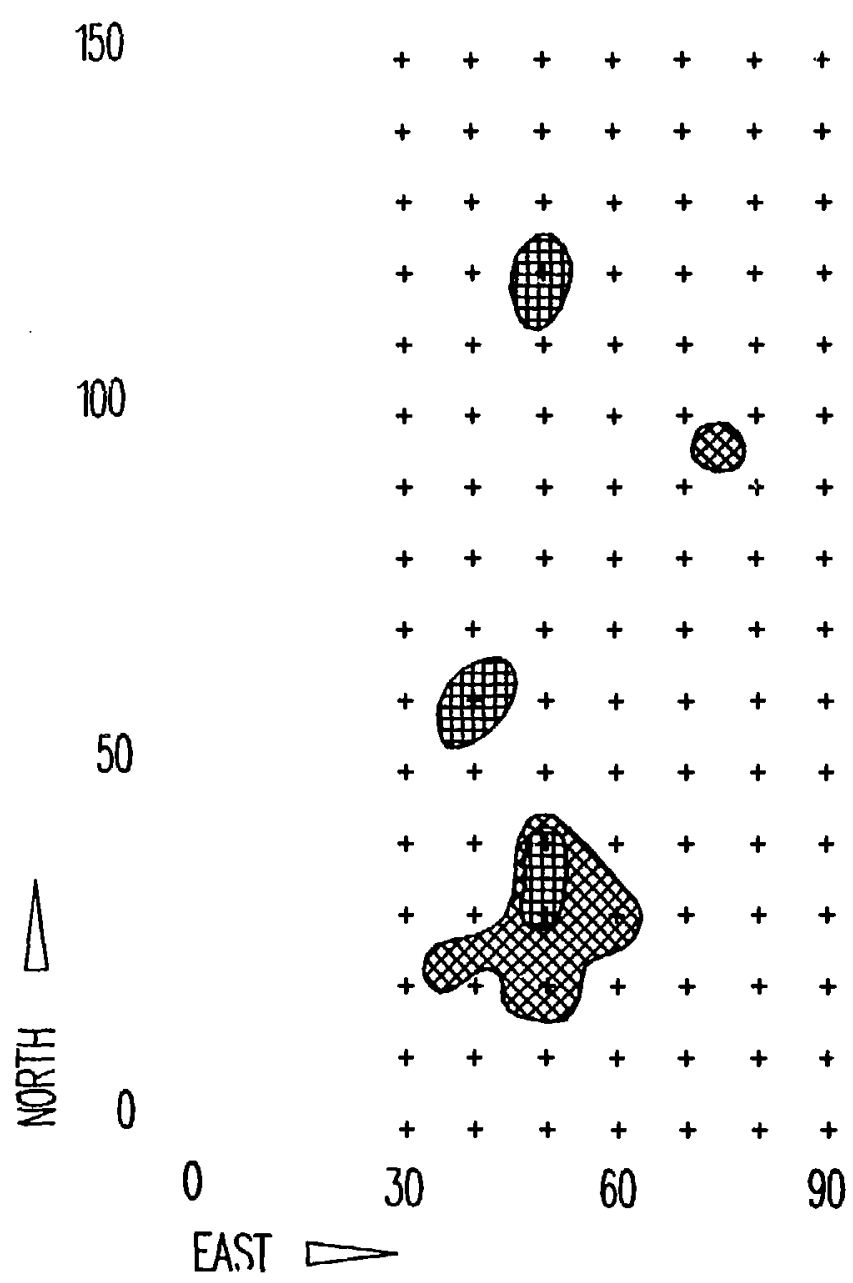

泟

NORTH

+ GRID INTERSECTIONS SCALE $=1: 400$ GRID INTERSECTION $=10 \mathrm{FT}$.

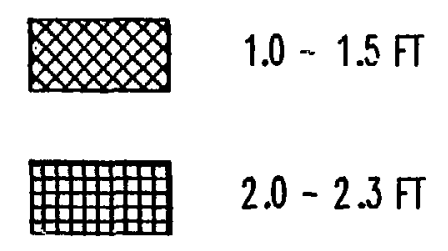

300

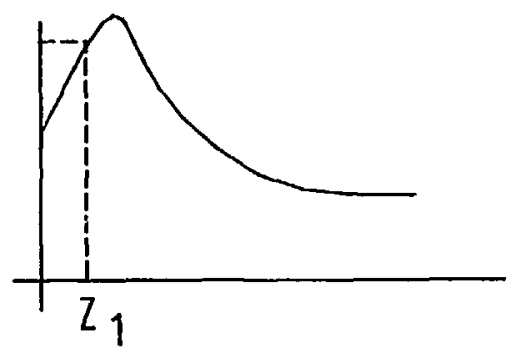

Figure 20. Depths to Top of $\geq 300 \mathrm{pci} /$ gram Layer. 


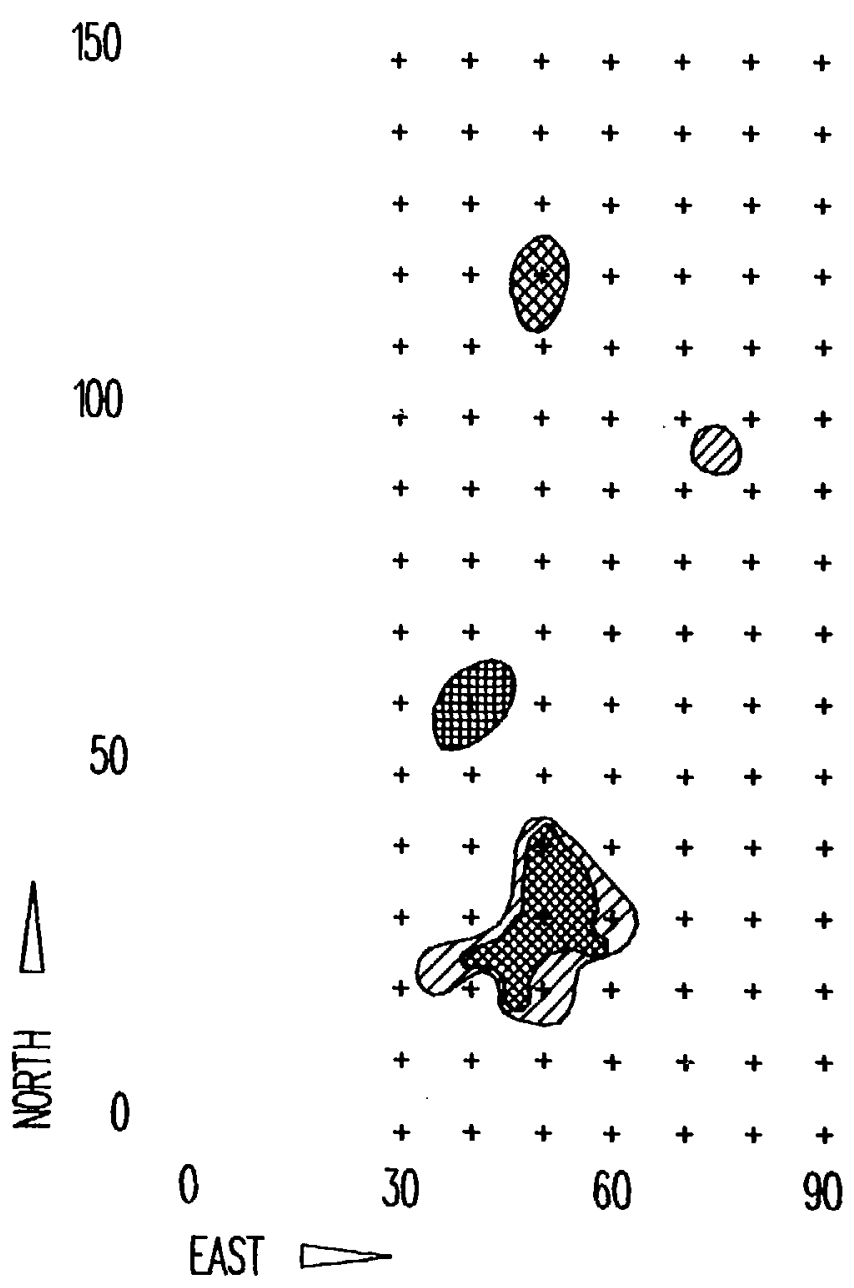

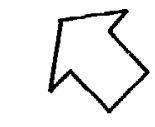

NORTH

+ GRID INTERSECTIONS SCALE $=1: 400$ GRID INTERSECTION $=10 \mathrm{FT}$.
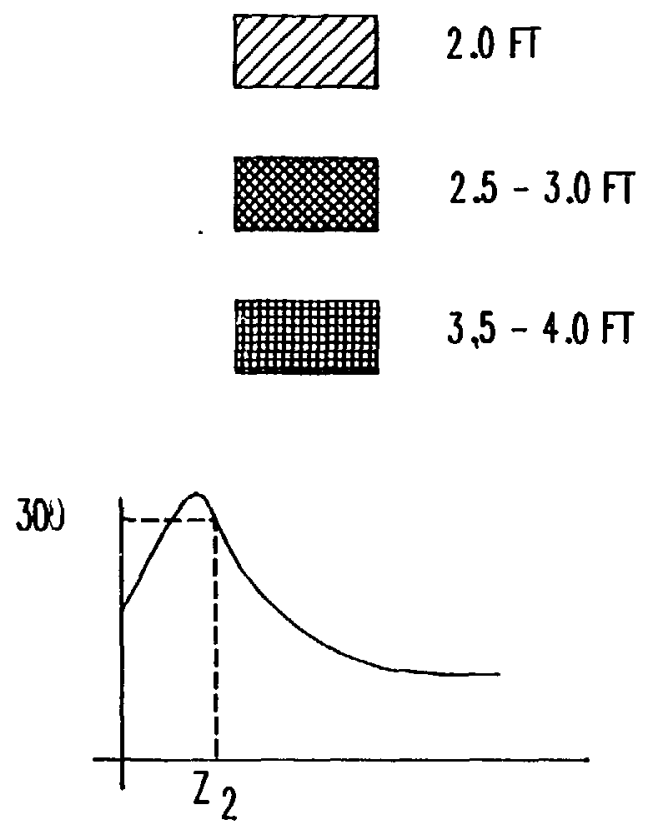

Figure 21. Depths to Bottom of $\geq 300 \mathrm{pci} /$ gram Layer. 


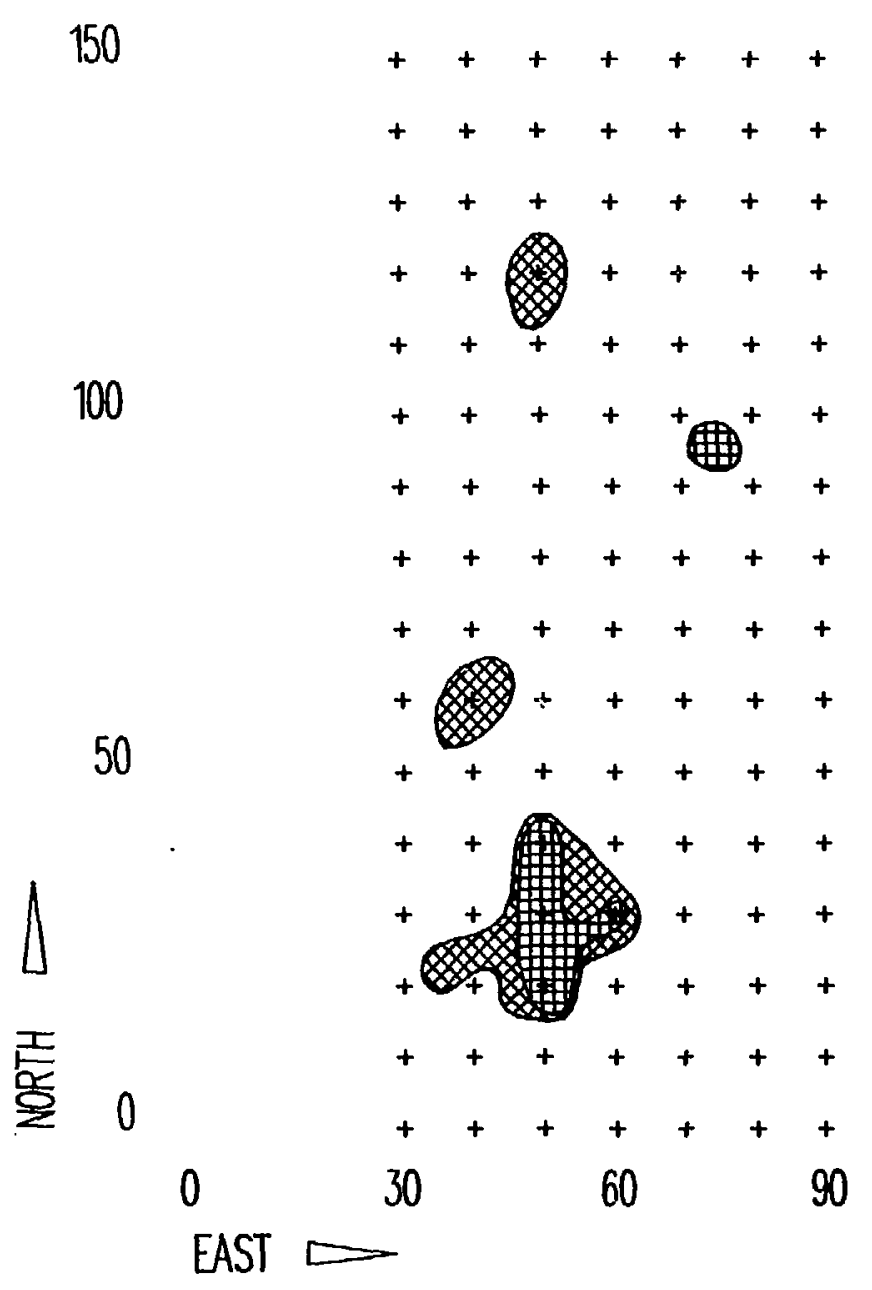

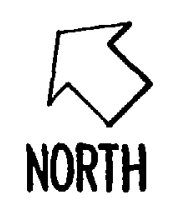

+ GRID INTERSECTIONS SCALE $=1: 400$ GRID INTERSECTION $=10 \mathrm{FT}$.

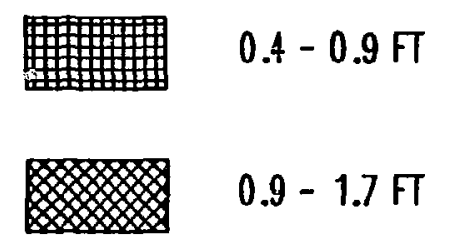

300

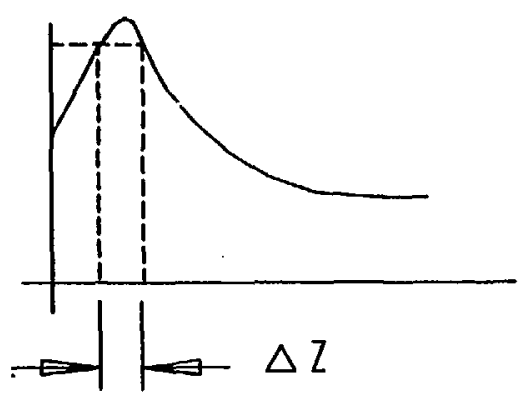




\section{CALCULATION OF VOLUDIES}

An estimate of the in-place volume of soil for a specified radium concentration is calculated by (1) measuring the areas of the depth contours and (2) multiplying the area in each closed contour by its average corresponding depth. The product of the contour area and its average depth gives the volume within that contour outline. For example, if the area of a 6-ft contour in Fig. 13 was $1000 \mathrm{ft}^{2}$, the volume in that contour would be $6,000 \mathrm{ft}^{3}$ (222 cubic yards). The volume for the entire test area is equal to the sum of the volumes associated with each closed depth contour. The contours were originally drawn on large maps and the areas were measured with an electronic digital planimeter. The contours were then digitized and transferred to a computer for final plctting at reduced size.

\section{RESULTS}

Using the method described in the previous paragraph, the following are estimates of the in-place volumes of contaminated sotl:

- The in-place volume of radium-contaminated soil for depths to a minimum concentration of $5 \mathrm{pCl} / \mathrm{g}$ is

1520 cubic yards $\pm 20 \%$

- The in-place volume of radium-contaminated soil for depths to a minimum of $15 \mathrm{pCi} / \mathrm{g}$ is

770 cubic yards $\pm 20 \%$

- The in-place volume of the layer of soil which has a radium concentration equal to or greater than $200 \mathrm{pCi} / \mathrm{g}$ is

40 culic yards $\pm 20 \%$

- The in-place volume of the layer of soil which has a radium concentration equal to or greater than $300 \mathrm{pCi} / \mathrm{g}$ is

30 cublc yards \pm 20 \% 


\section{QUALITY ASSURANGE}

The ANL technique for determining the depth profile of radiun contamination in soil has been field-tested at several sites (ANL-85, ANL-89; ANL-90).

The uncertainty in estimating the volume of radium-contaminated soil on a site is primarily determined by the grid spacing of measurements, and the correlation between detector-count rate and radium-activity concentration $(\mathrm{pCi} / \mathrm{g})$ in soil. For tubes placed on a $10 \mathrm{ft} x 10 \mathrm{ft}$ grid and for our current correlation between detector-count rate and $\mathrm{pCi}-\mathrm{Ra} / \mathrm{g}$ of soil, the uncertainty of our volume estimates is estimated to be about \pm 208 (based on assumptions about homogeneity of contamination within each grid and on method of extrapolation between depth profiles withir grids and between adjacent grids).

The representativeness of the data is controlled solely by the grid spacing. The detector inserted into the soil "sees" a cylinder of soil with an effective radius of about two feet.

The precision of the technique was assured by frequently checking the detector/counter system against a ${ }^{137} \mathrm{Cs}(662-\mathrm{keV})$ check suurce and by remeasuring the same tubes at different times. Precision is influenced primarily by the stabiitty of the detector/counter system.

The detector system was calibrated to have a peak response at $662 \mathrm{keV}$ $\left(1^{3} \mathrm{Cs}\right)$ and was checked at the beginning of each set of measurements. 
32

ACKNOWLEDGMENTS

All of the drawings were done by David $W$. Reilly. The contaminationdepth-profile graphs in Appendix B were plotted by T. William Knoerzer and David R. Pepalis. Gamma-ray spectroscopy analysis of soil samples was done by Albert E. Lissy and Charlotte M. Sholeen. Thanks are given to Millie Papal and Marie D'Arpa for typing the report and to Charlotte M. Stolen for her careful editing of the technical details of the report.

We also thank James Neiheisel, the Project Officer, and Ben Hull for their guidance, patience, and assistance. Joseph Wood, Mark Cotton, and Shawn Logan assisted with the field work. 
REFERENCES

CDM-89 Report dated April 3, 1989, from Camp, Dresser, and McKee, Inc. DOC. NO. 135-FS3-RT-GXRM.

EERF-89 Memo dated September 13, 1989, from Joseph G. Wood, Eastern Environmental Radiation Facility to Larry Coe, Sandy Cohen and Associates.

NCRP-87 National Council on Radiation Protection and Measurements, Exposure of the Population in the United States and Canada from Natural Background Radiation, NCRP Report No. 94, 1987, Table 4.3, page 61. (National Council on Radiation Protection and Measurements, Bethesda, Maryland.)

ANL-85 Post Building Removal Assessment of Radioactivity in Soil at the Luminous Processes. Inc. Site. Ottawa. Illinois. September-0ctober 1985, Argonne National Laboratory Report No. ANL/OHS/HP-85/108, October 1985 .

ANL-89 Estimate of Volume of Radium Contaminated Soll on Five Sites in Ottawa, I11inois, September-October 1989, Argonne National Laboratory Report No. ANL/ESH/TS-89/100, March 1989.

ANL-90 Radiological Oversight and Certification Report for the Lansdowne Property, 105-107 East Stratford Avenue, Lansdowne. Pennsylvania. August 1988-June 1989, Argonne National Laboratory Report No. ANL/ESH/TS-90/101, February 1990. 


\section{APPEIDIX A}

FIELD INSTRUMENTS AND EQUIPMENT

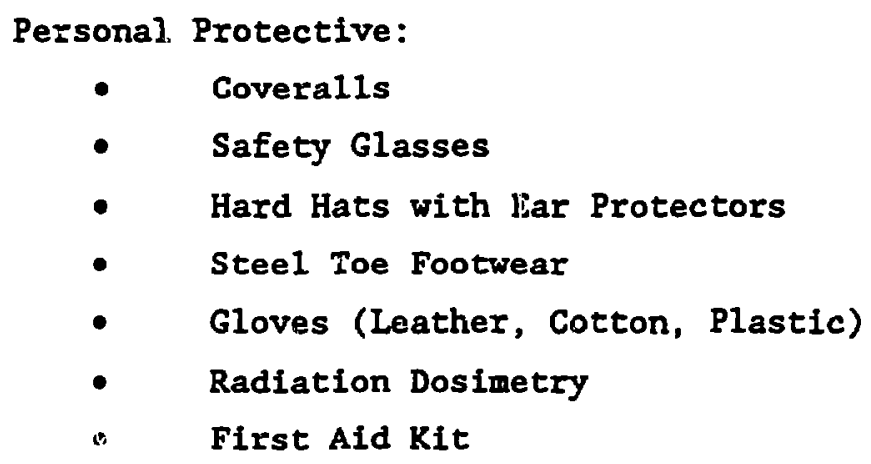

Land Survey:

- Sledge Hammer (10 1b)

- Stakes/Hubs (in. gden)

- Survey Rope (300')

- Measuring Tapes (25'; 300')

- Flagging/Ribbon

- Lensatic Compass

- Transit with Tripod

- Field Survey Data Books

Tube Driving:

- Pionjar Model 120 Gas-Powered Hammer with Accessories for Driving 1-In-Dia.Electrical Metal Tubes and 2-In-Dia.)

- Ten-Foot-Long Tubes (1 In-Dia. EMT)

- Tube Points (ANL Design)

- Tube Couplings (ANL Design)

- Jack with Chain

- Portable Pipe-vise Stand

- Gasoline/Two-Cycle $0 i 1$

- Tools (Saw, Hammer, Files, etc.) 
Radiation Detection:

- 241Am Check Source (Smoke Detector Source)

- $\quad{ }^{137} \mathrm{Cs}$ Check Source (Button)

- Gamma Check Source (Gas Mantle-Thorium)

- Exposure-Rate (microR) Meter (Eberline PRM-7)

- Surface Gamma Detector (Eberline PRM 5-3 with Shielded PG-2 Detector)

- Sub-Surface Gamma Detector (Ludlum Model 2220 or 2221 with an ANLfabricated NaI(Tl) $3 / 8$ In $x 3 / 8$ In or BGO $1 / 2$ In $x 1 / 2$ In Detector

- Geiger-Mueller Detector (Eberline E-530 with End-Window G-M Detector)

Soil Sampling:

- Shelby Tube Kit

- Hand Trowels

- Shovel

- Zjp-Lock Plastic Bags

- Auger (3-In-Dia.) Kit

Data Analysis:

- Laptop Computer (Zenith Z-183)

- Portable Printer (Diconix/Kodak)

- Portable Electronic Planimeter and Digitizer (Ushikata Model X-PLAN 360i)

- Computer-Aided Drafting Program (Drafix CAD Ultra)

- Drafting Board

- Data-Base Program (DBASE IIIt)

- Semi-Log Graph Paper

Transportation:

- ANL/Government Vehicle (ME-58), Chevrolet Suburban 4X4 with Heavy Duty Suspension 
APPERIDIX

GRAPHS OF CONTAMINATION DEPTH PROFILES 

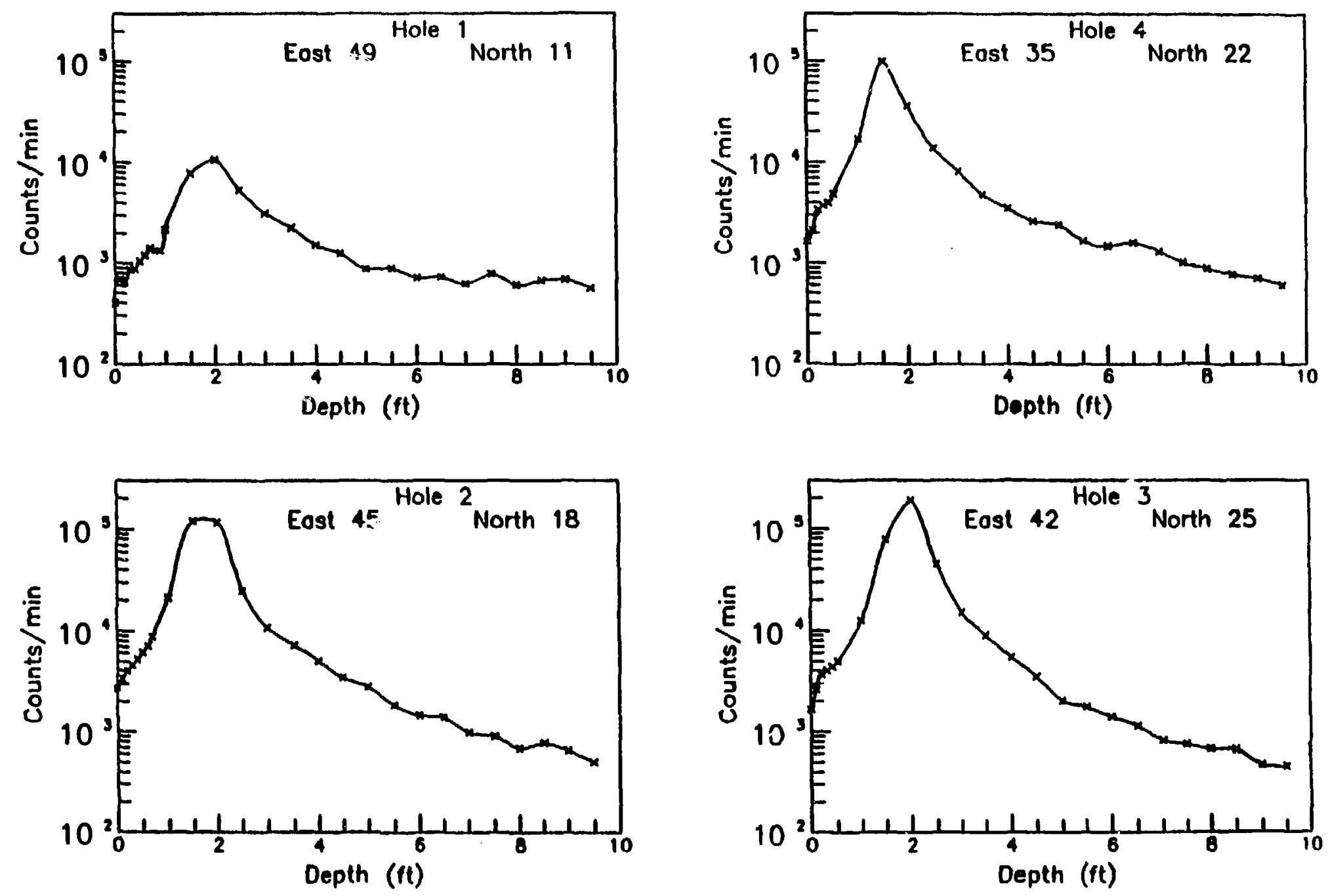

Figure B1 Contamination Depth Profiles at Barrows Field Park, Glen Ridge. N.J. 

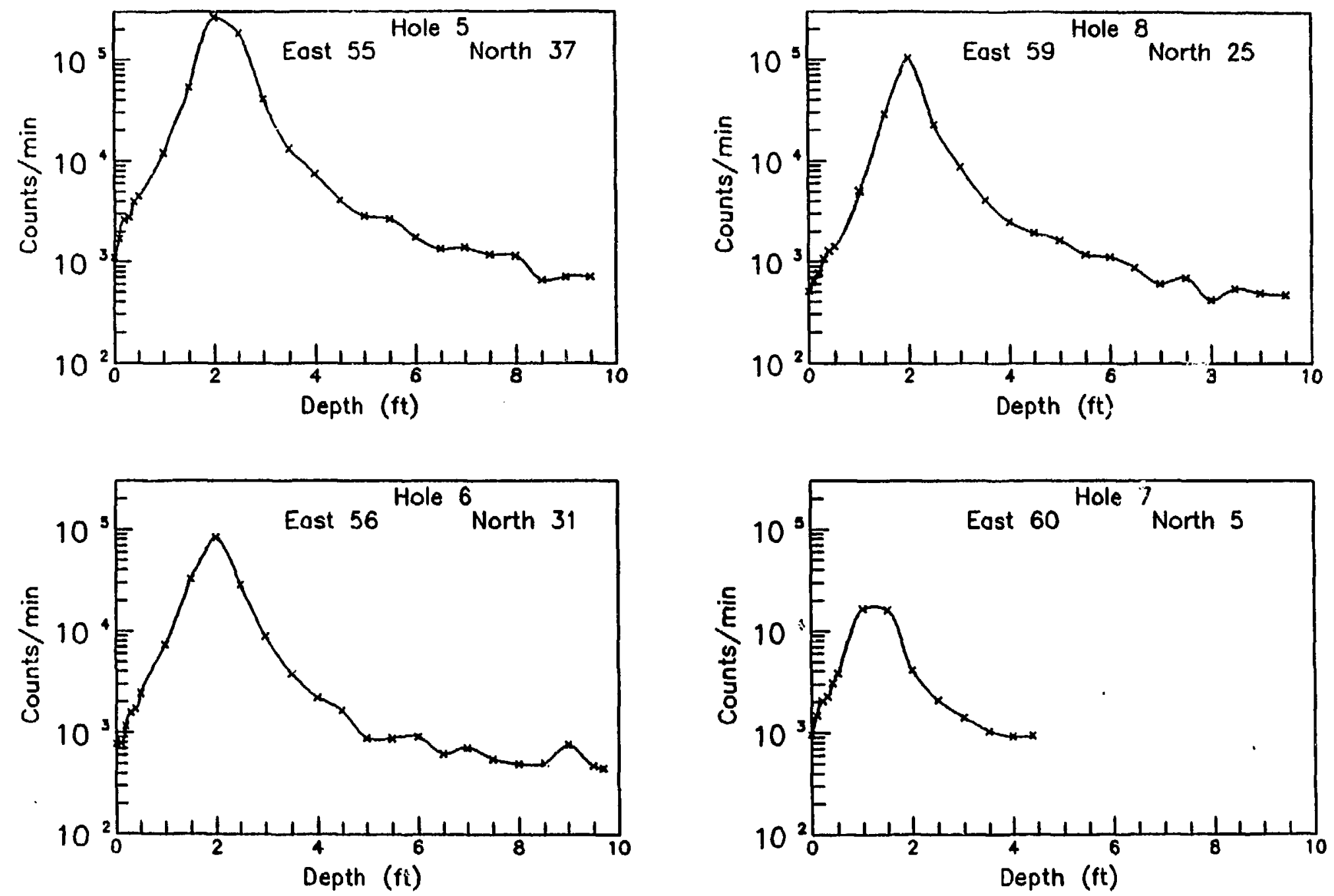

Figure B2 Contamination Depth Profiles at Barrows Field Park, Glen Ridge, N.J. 

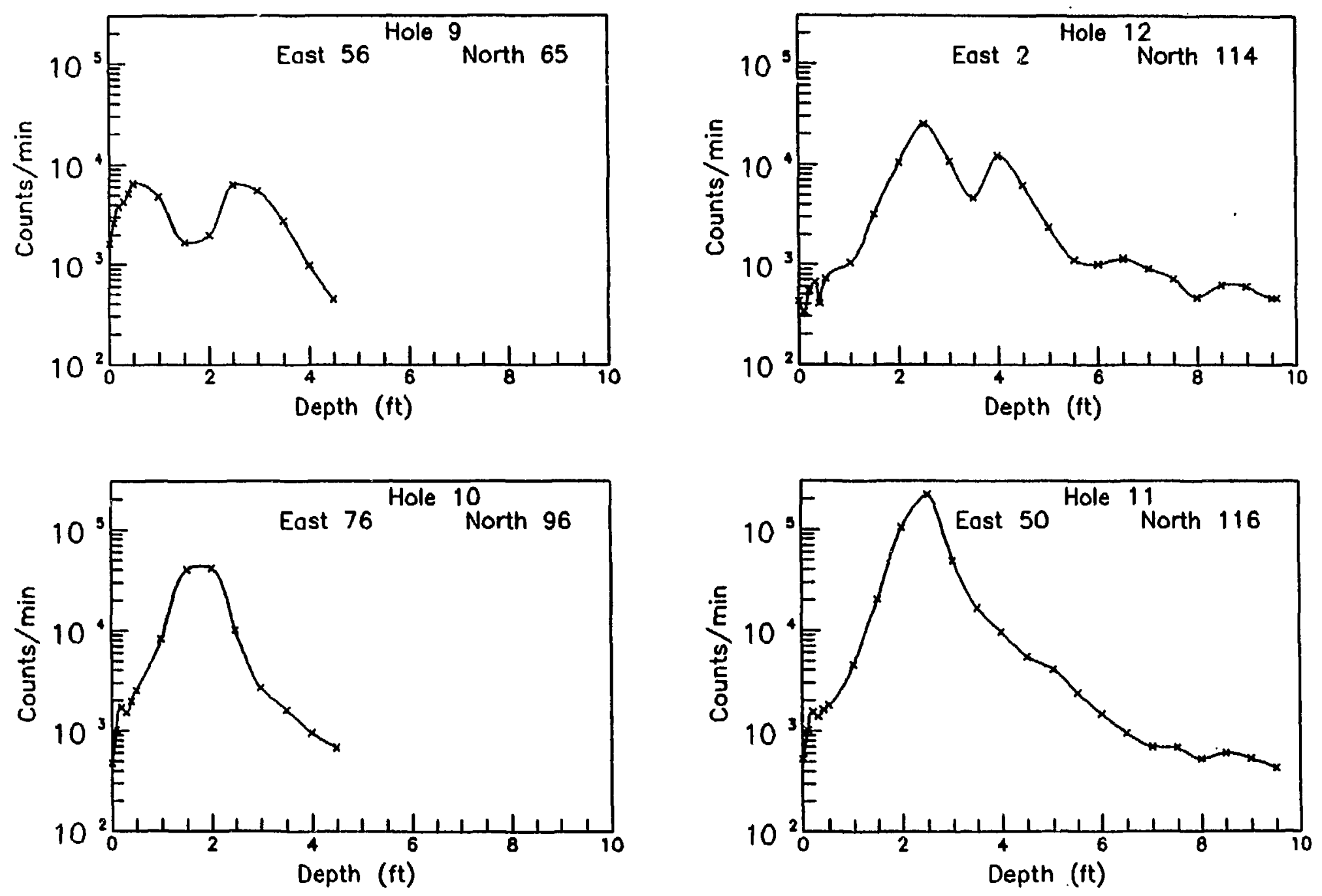

Figure B3 Contamination Depth Profiles at Barrows Field Park, Glen Ridge, N.J. 

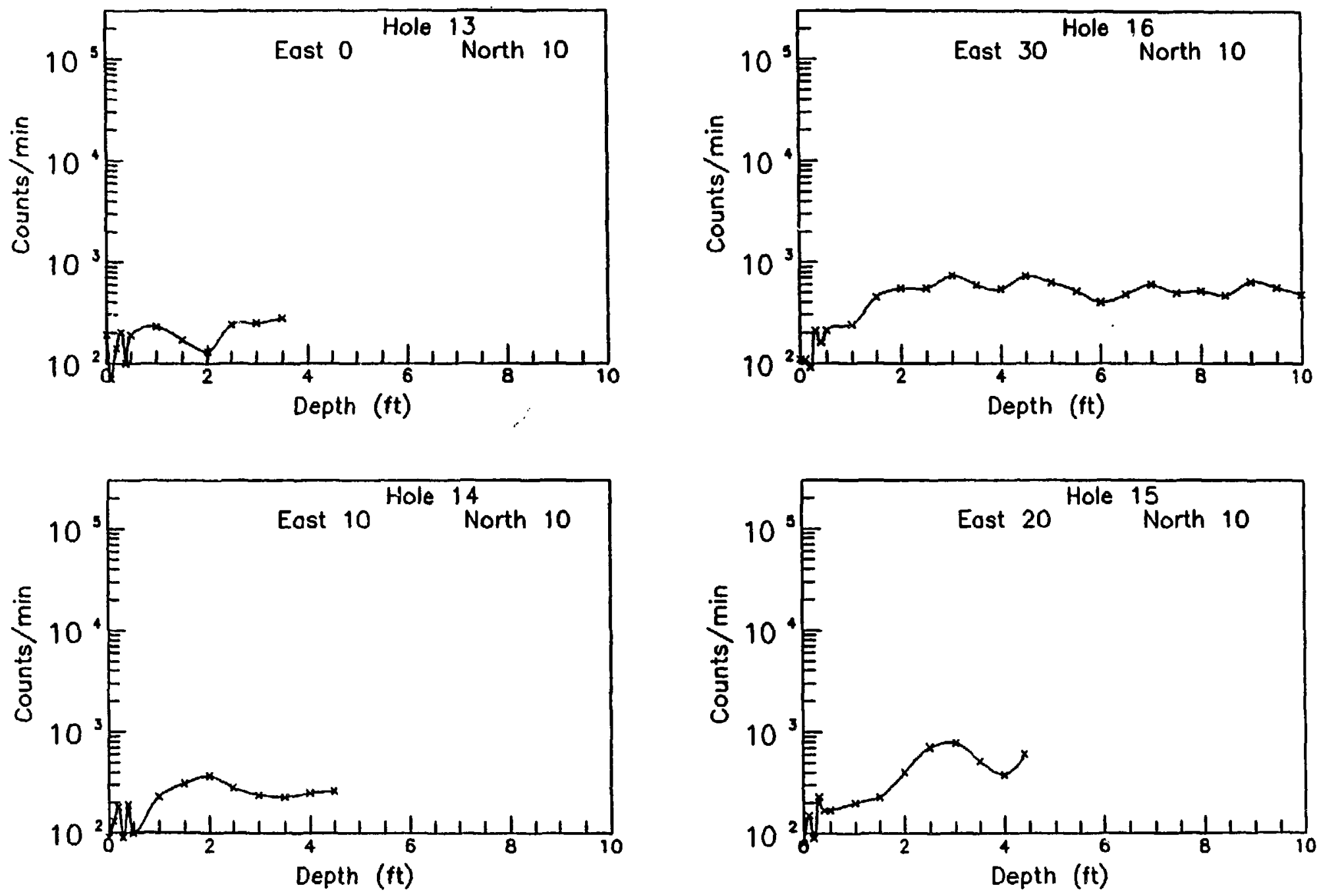

Tigure B4 Contamination Depth Profiles at Barrows Field Park, Glen Ridge, N.J. 

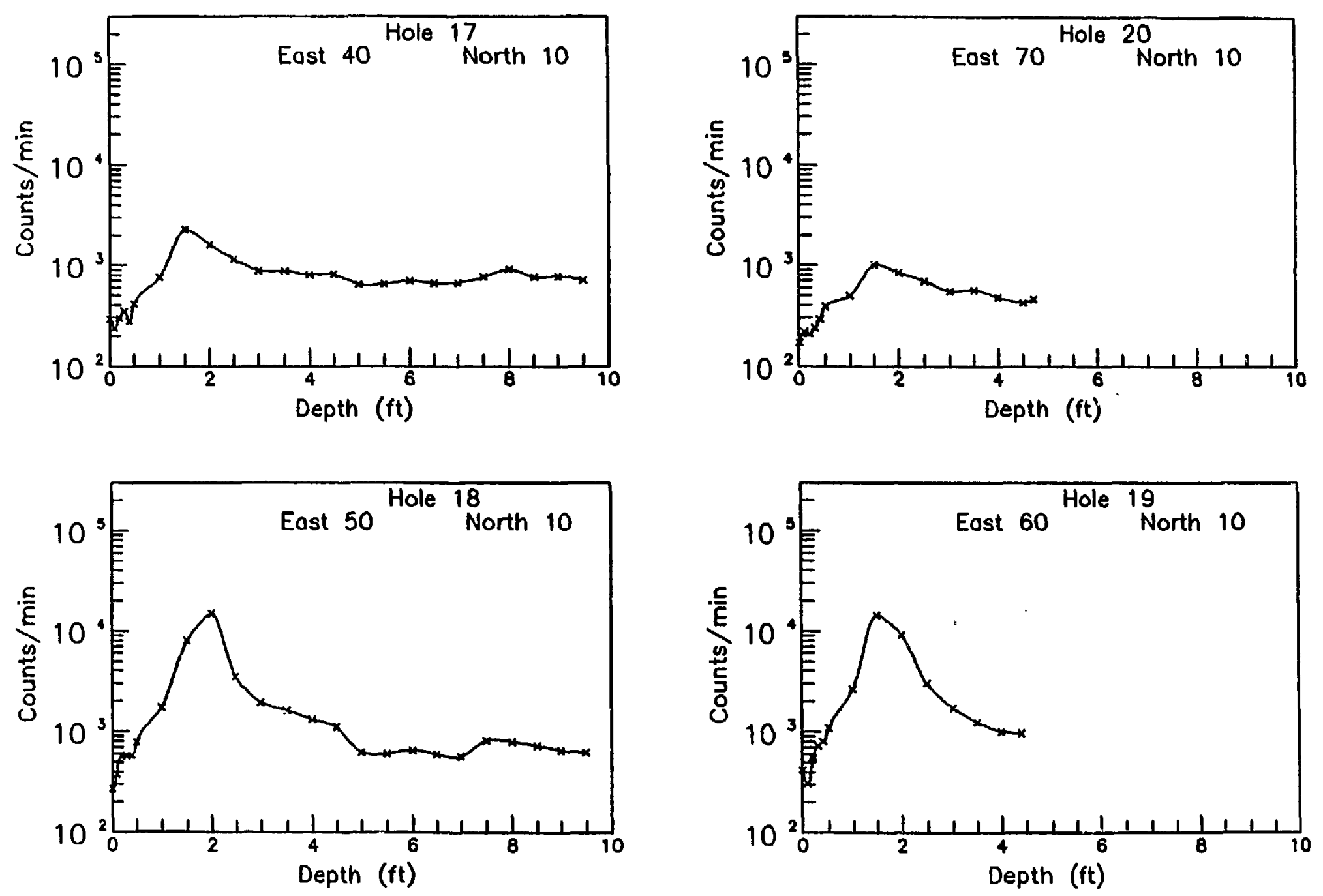

Figure B5 Contamination Depth Profiles at Barrows Field Park, Glen Ridge, N.J. 

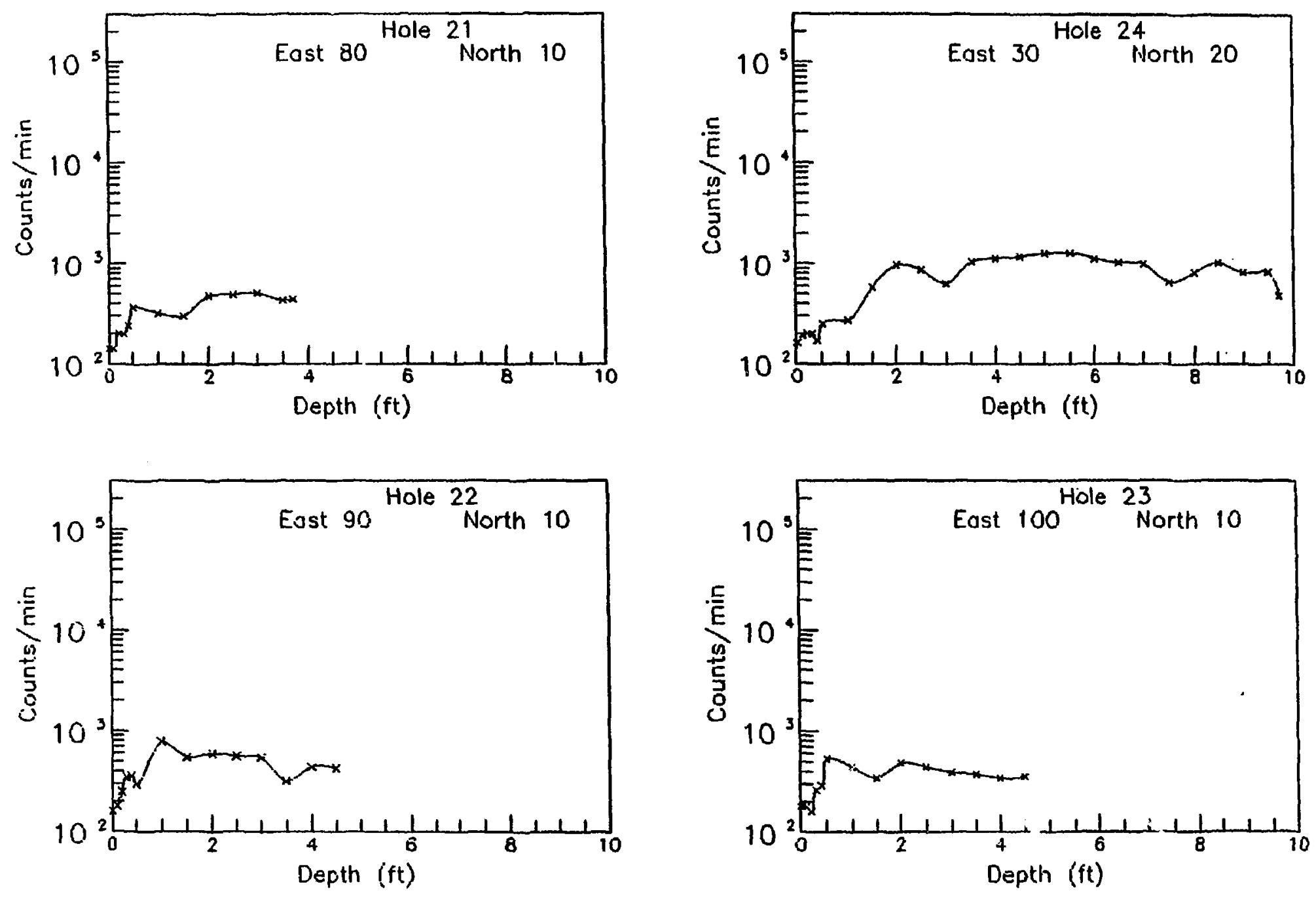

Figure 6 Contamination Depth Profiles at Barrows Field Park, Glen Ridge, N.J. 

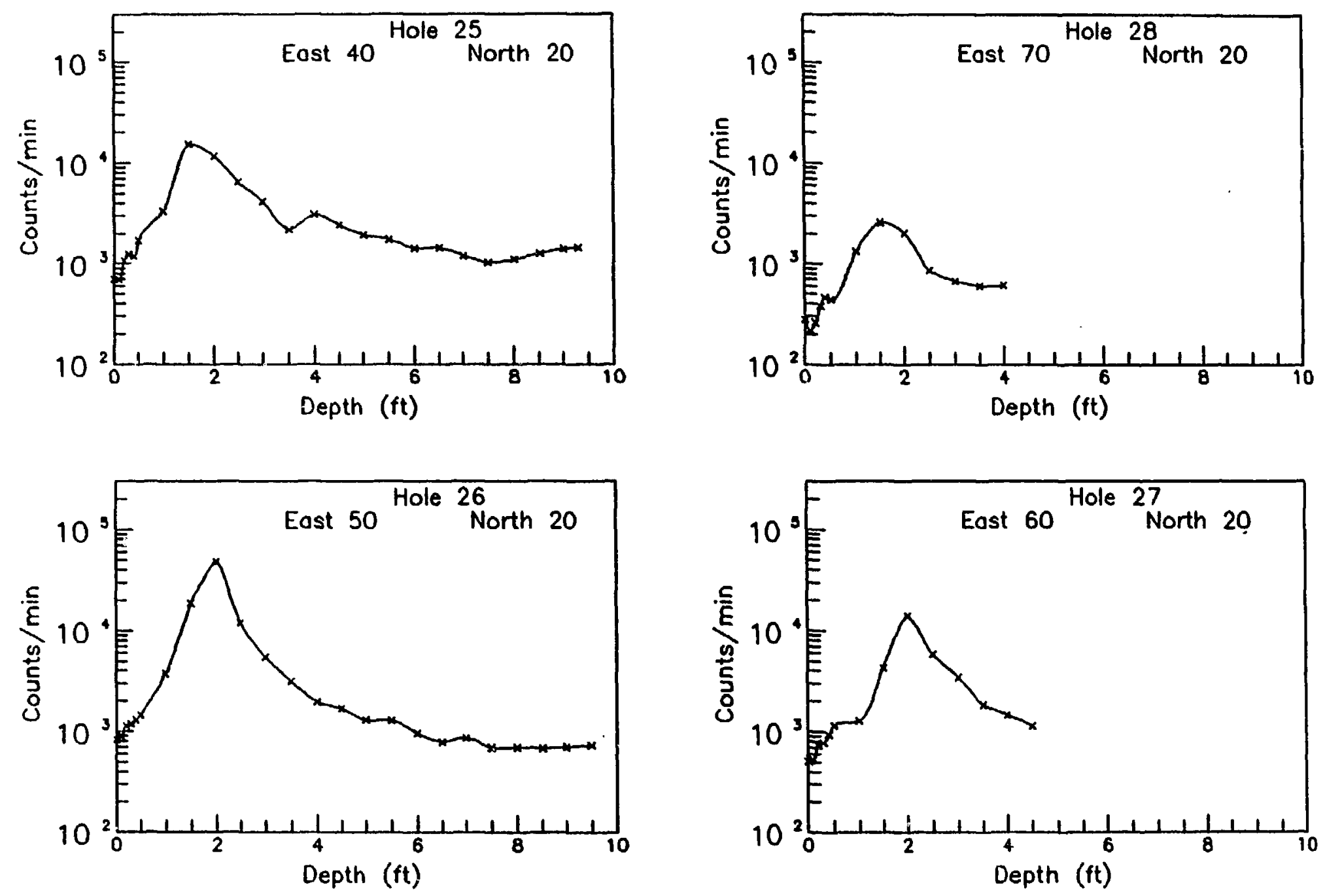

Figure B7 Contamination Depth Prufiles at Barrows Field Park, Glen Ridge, N.J. 

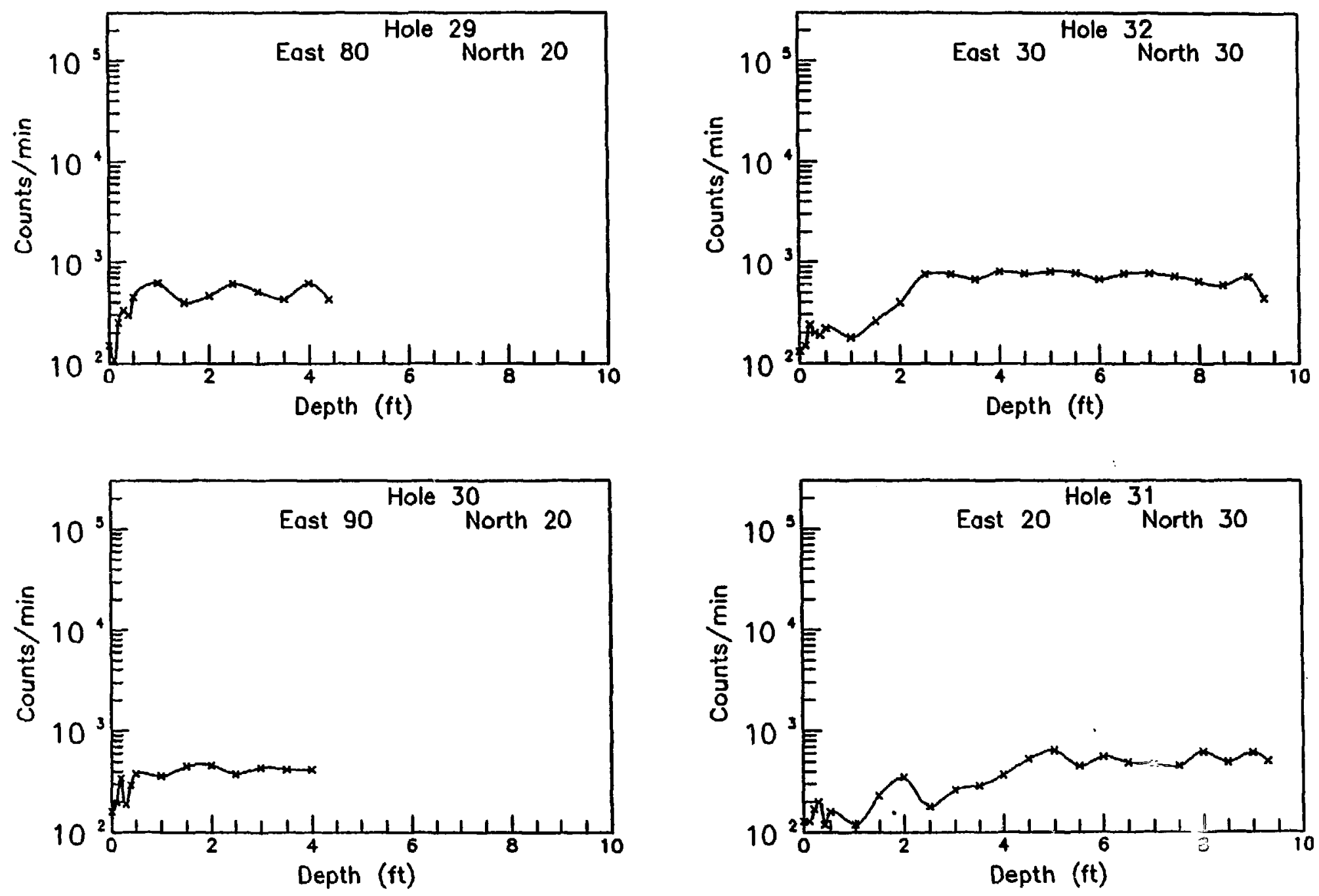

ث

Figure BB Contamination Depth Profiles at Barrow s Field Park, Glen Ridge, N.J. 

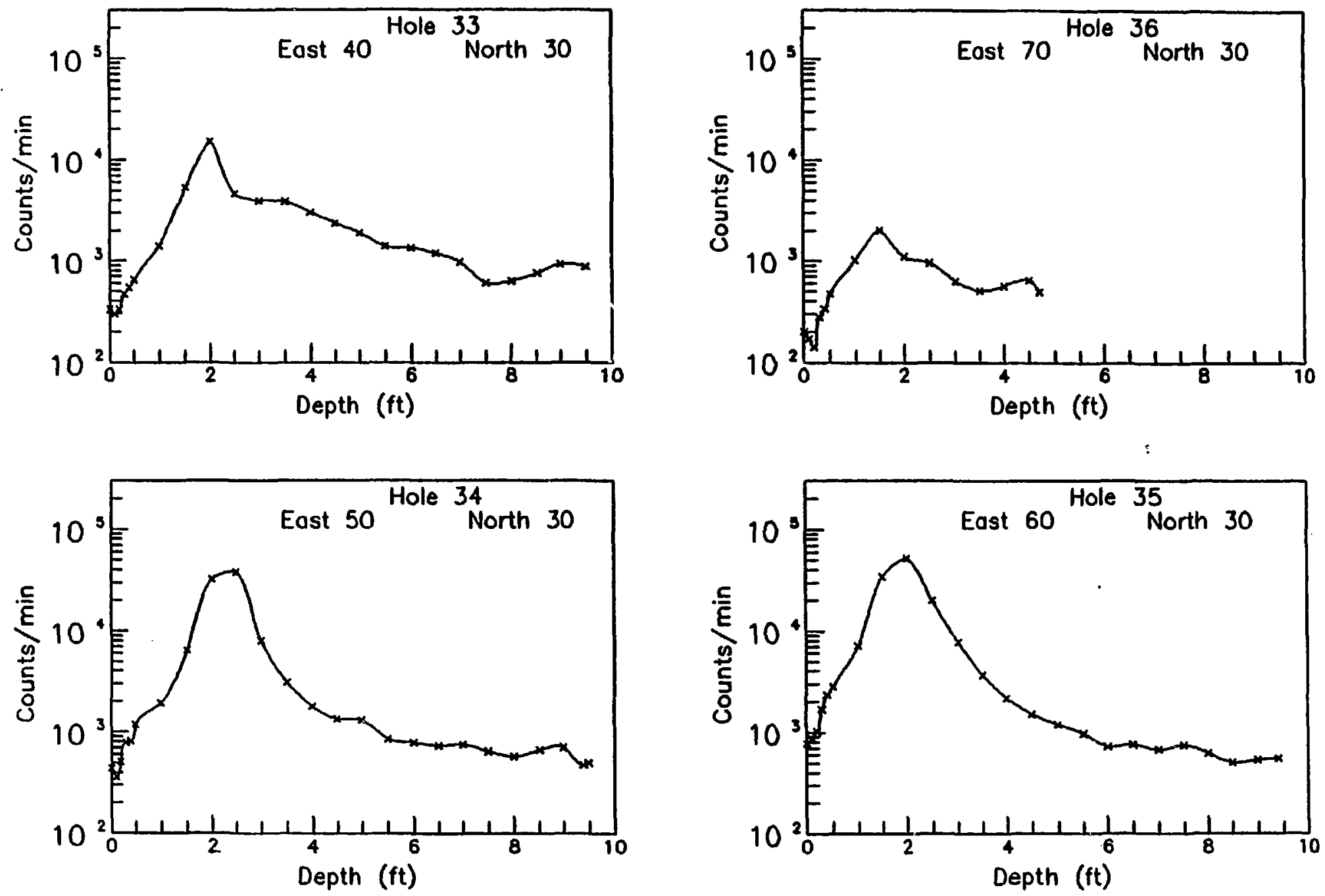

fิ

Figure B9 Contamination Depth Profiles at Barrows Field Park, Glen Ridge, N.J. 

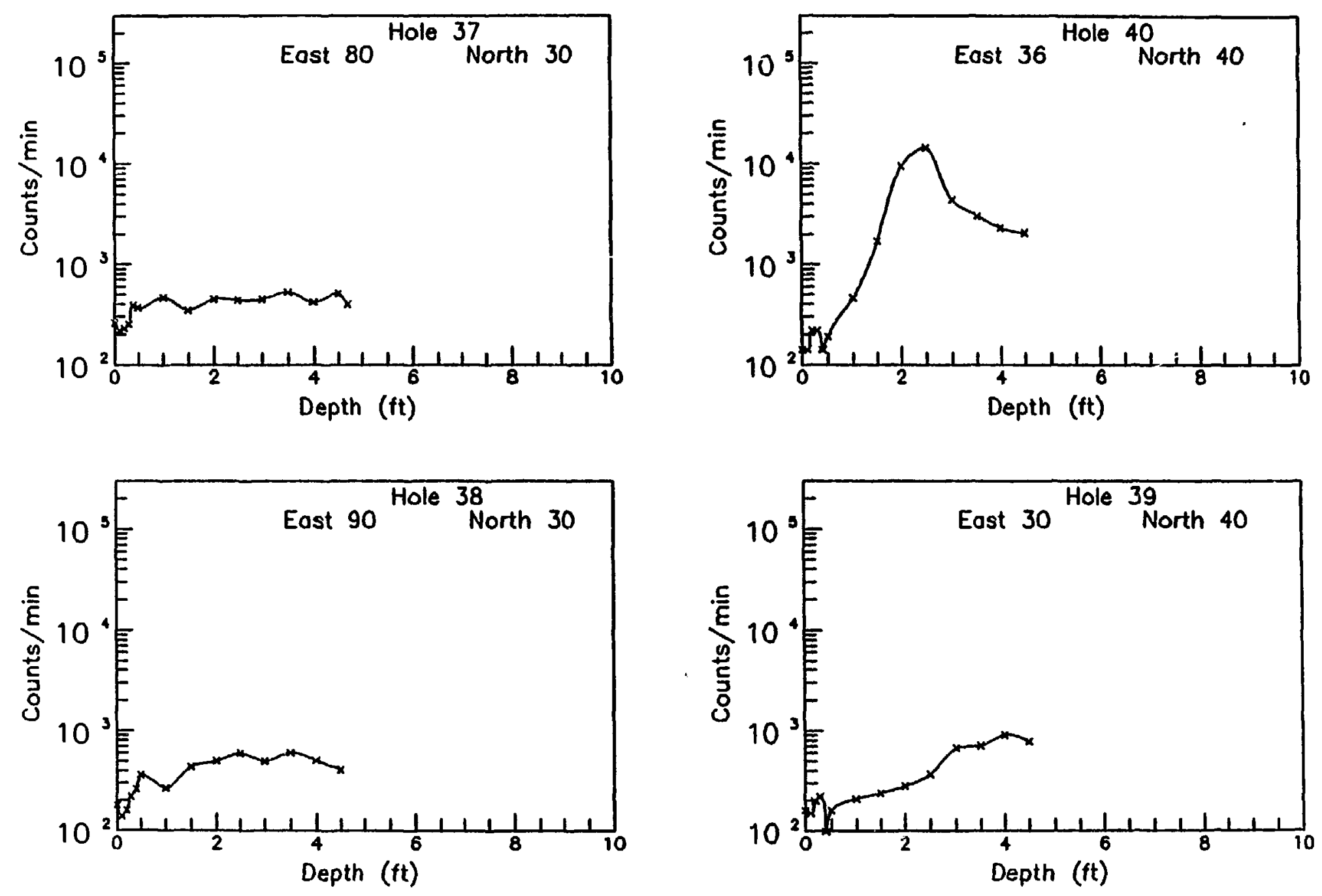

Figure B10 Contamination Depth Profiles at Barrows Field Park, Glen Ridge, N.J. 

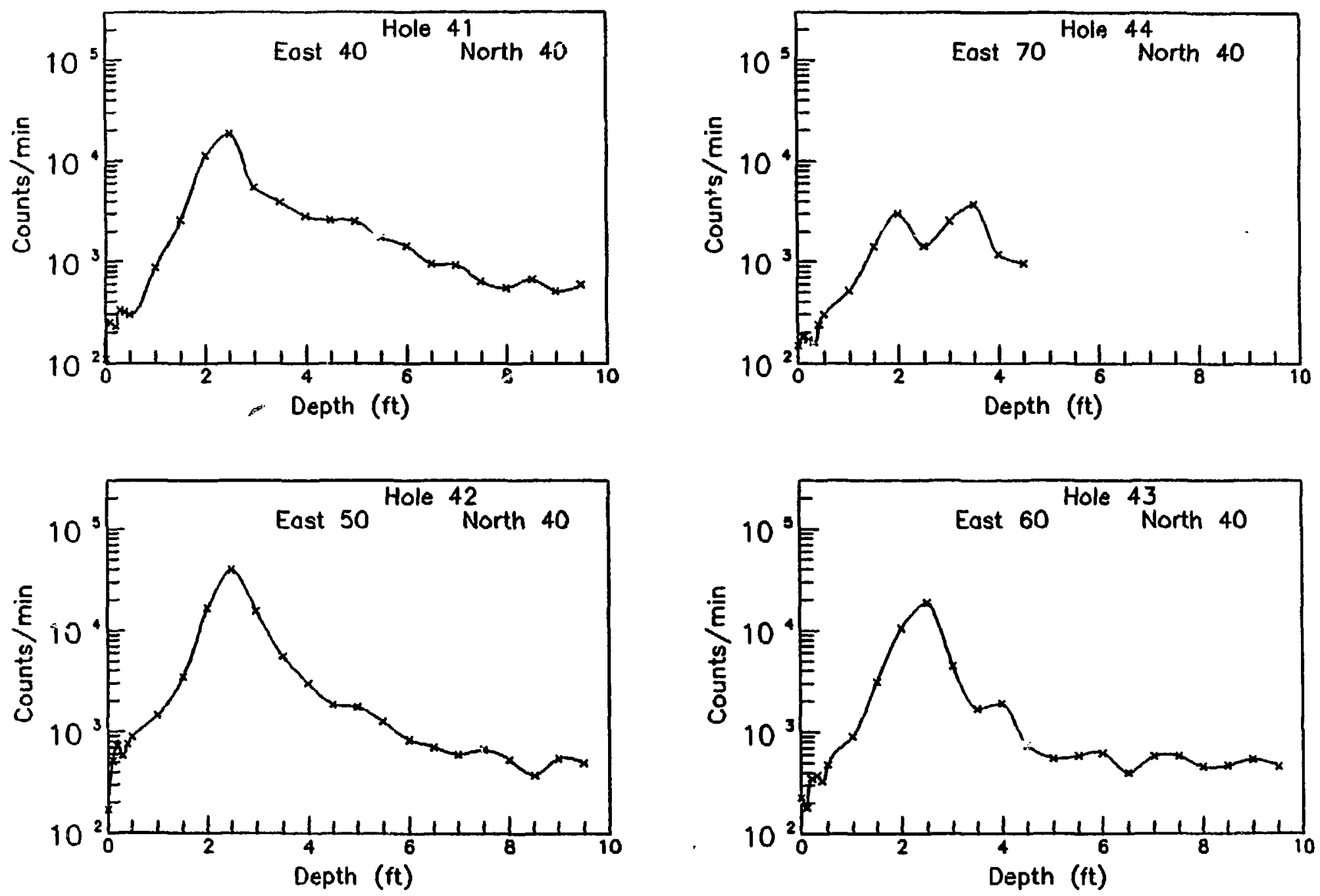

$\underset{\infty}{\infty}$

Figure $\mathrm{B} 11$ Contamination Depth Profiles at Barrows Field Park, Glen Ridge, N.J. 

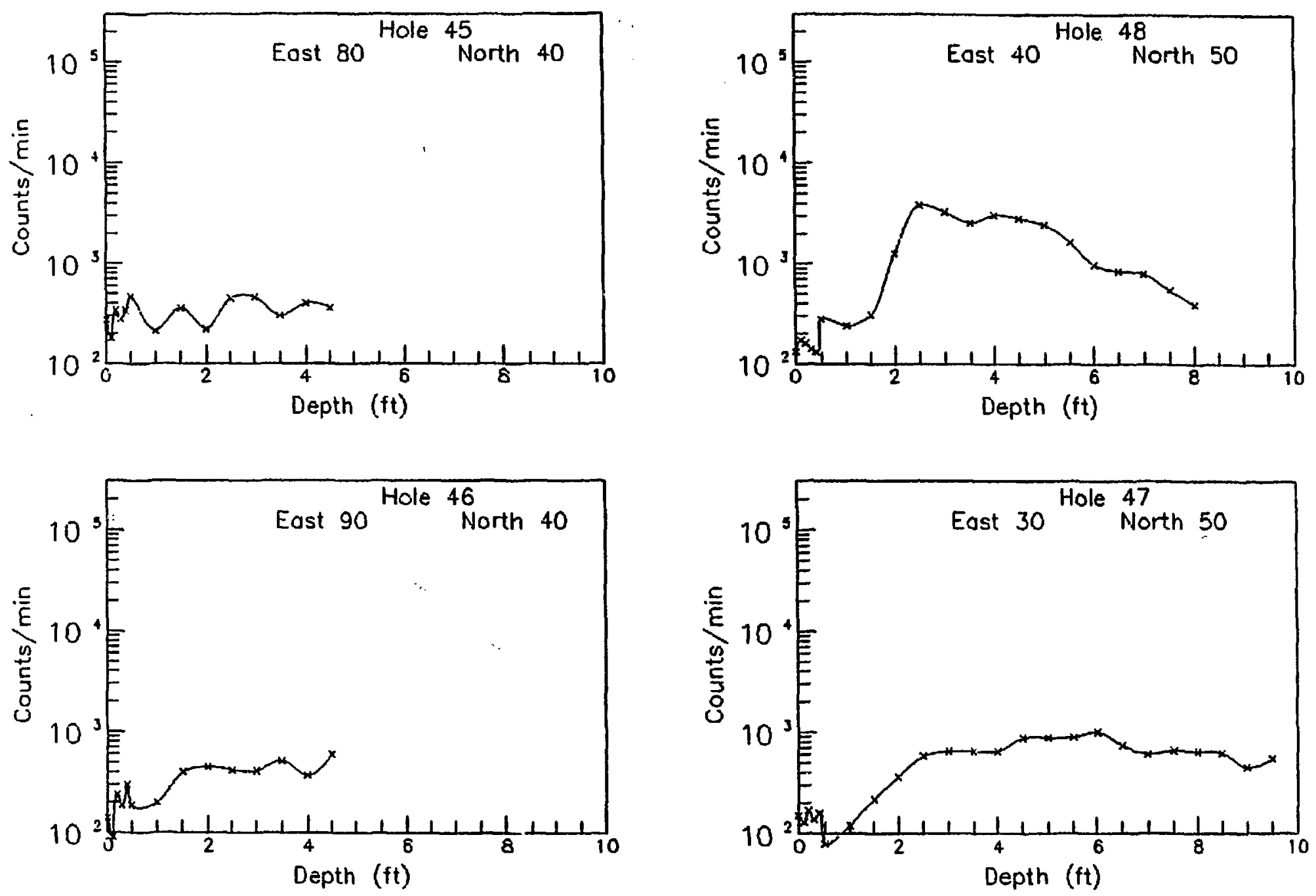

Figure 12 Contamination Depth Profiles at Barrow s Field Park, Glen Ridge, N.J. 

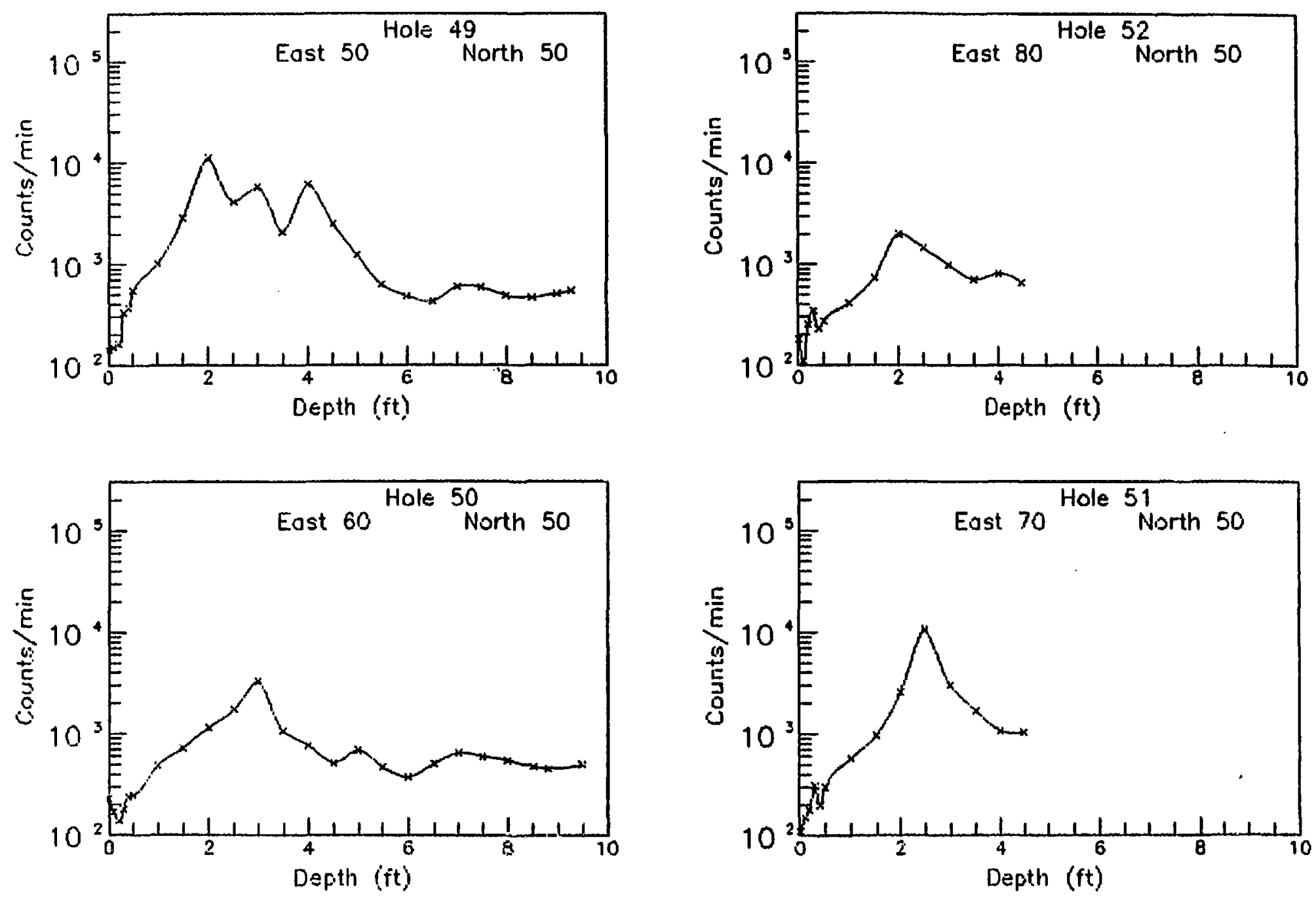

능

Figure 13 Contamination Depth Profiles at Barrows Field Park, Glen Ridge, N.J. 

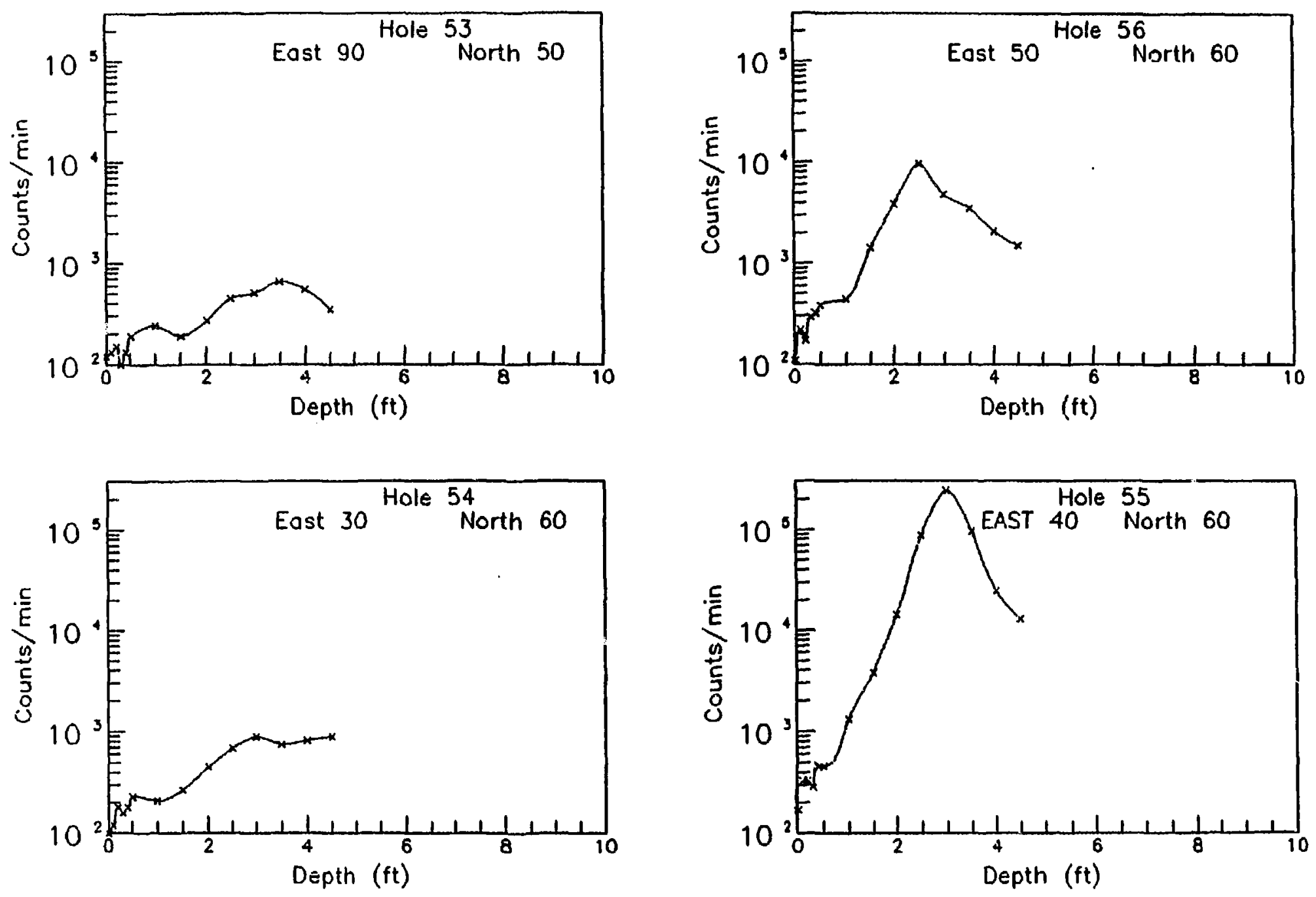

Figure 14 Contamination Depth Profiles at Barrows Field Park, Glen Ridge, N.J. 

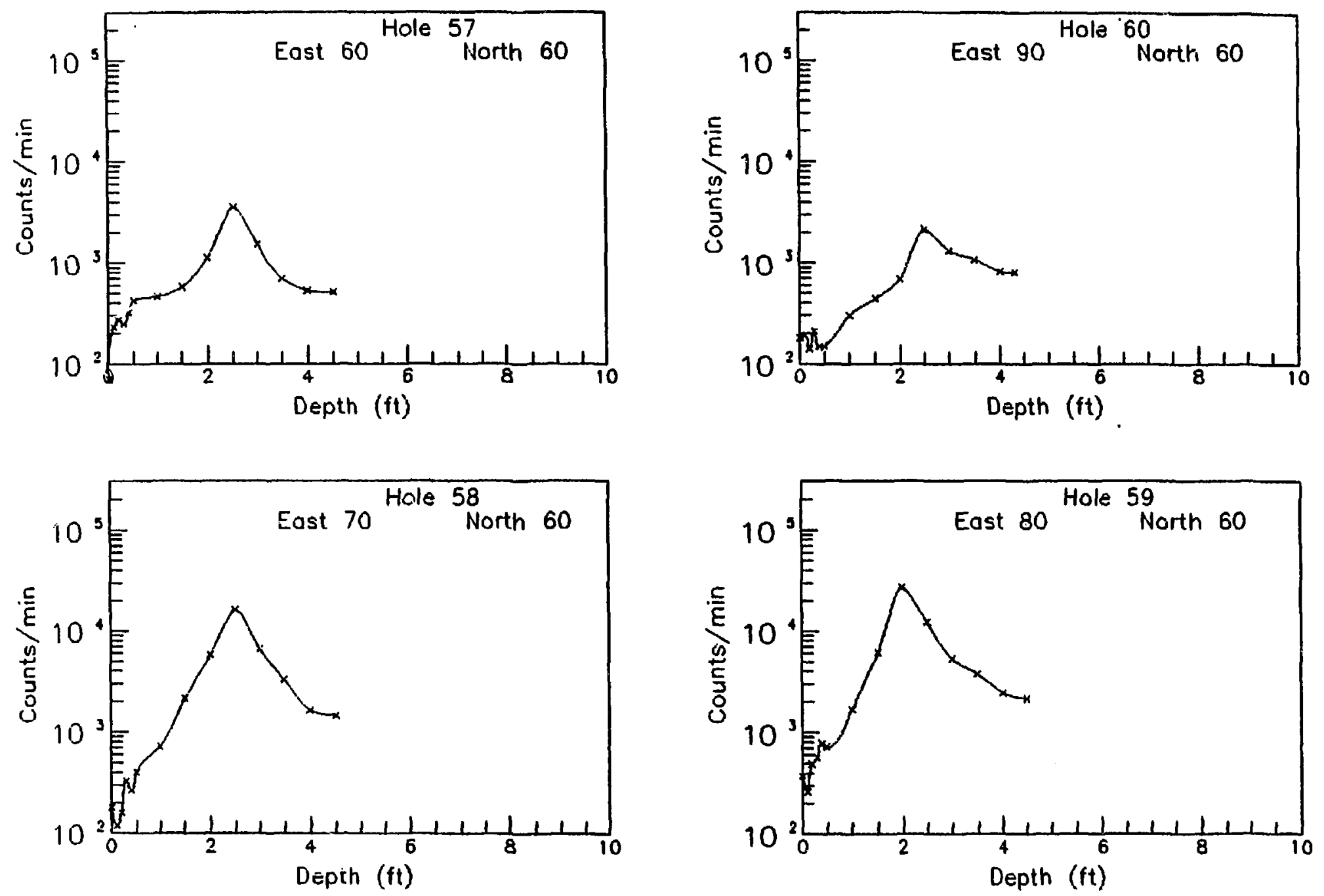

Figure 15 Contamination Depth Profiles at Barrows Field Park, Glen Ridge, N.J. 

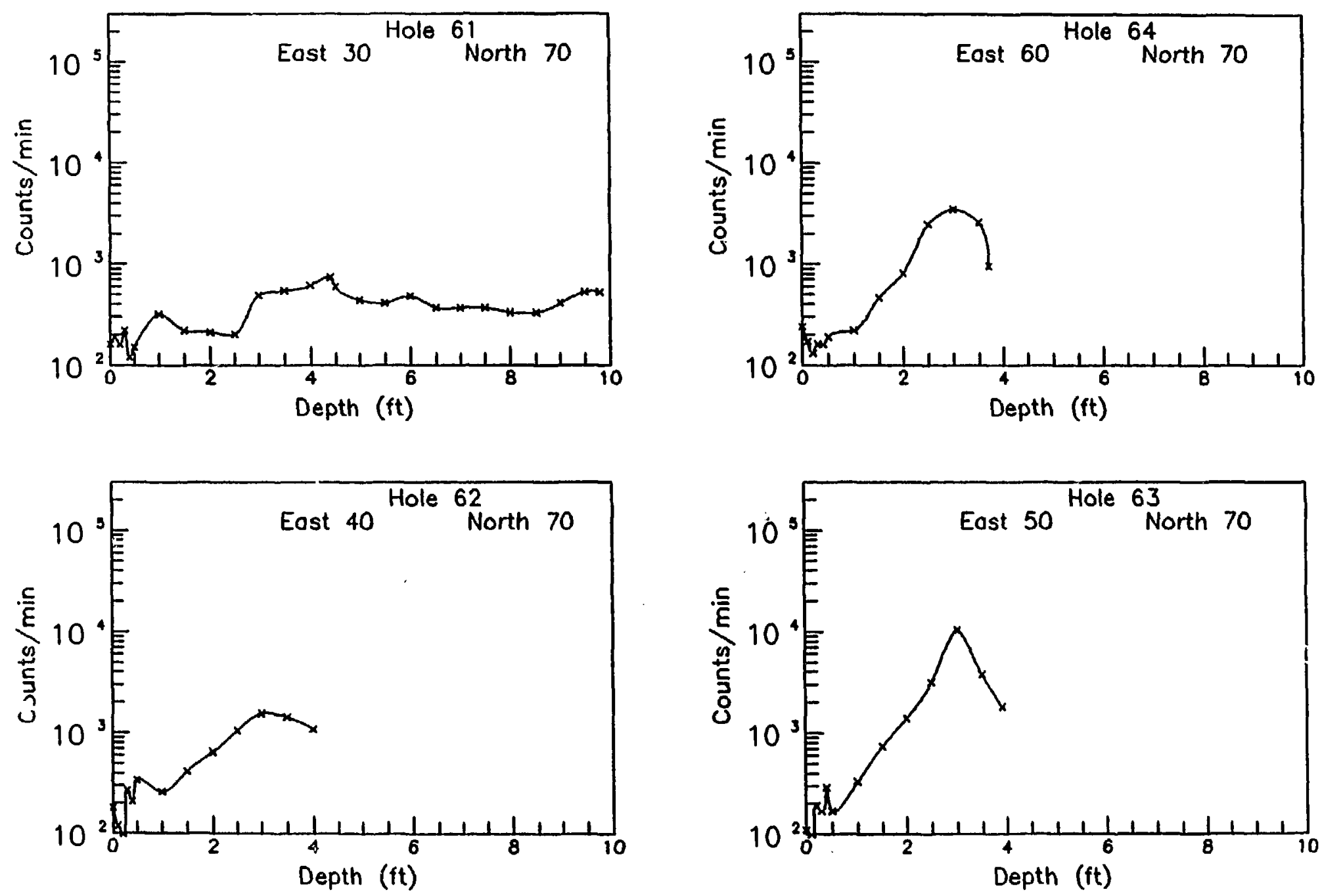

Figure B16 Contamination Depth Profiles at Barrows Field Park, Glen Ridge, N.J. 

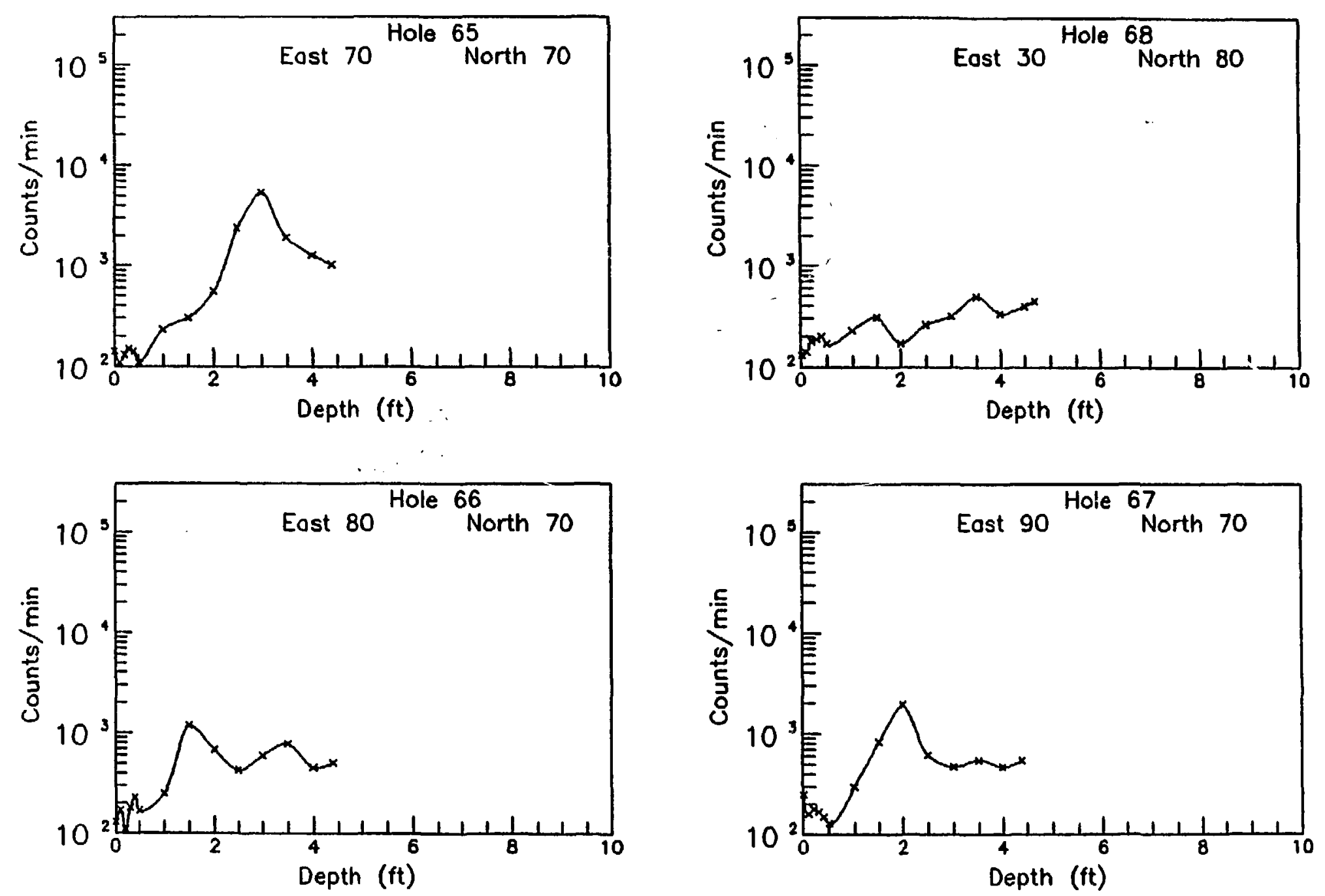

Figure B17 Contamination Depth Profiles at Barrows Field Park, Glen Ridge, N.J. 

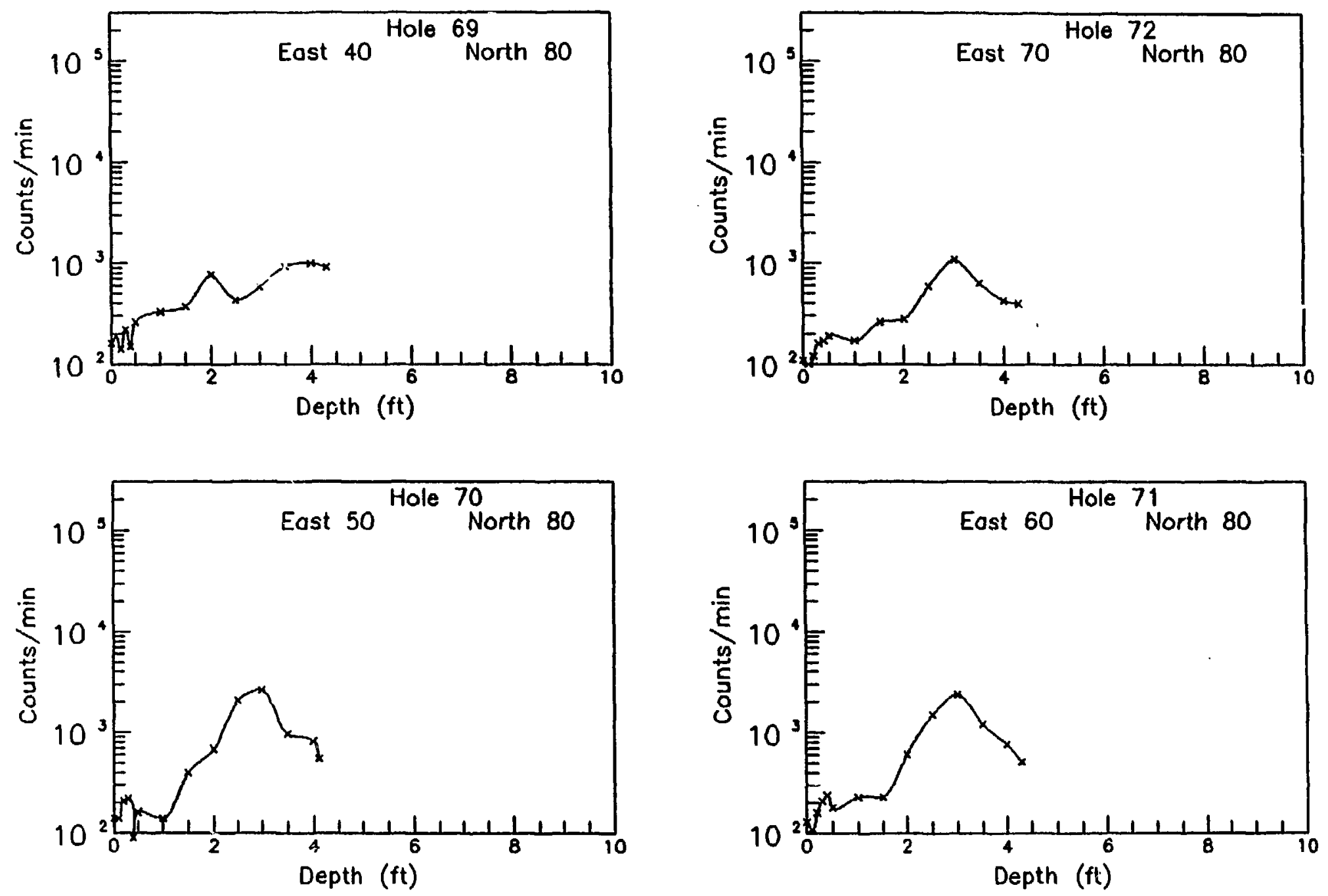

Figure B18 Contamination Depth Profiles at Barrows Field Park, Glen Ridge, N.J. 

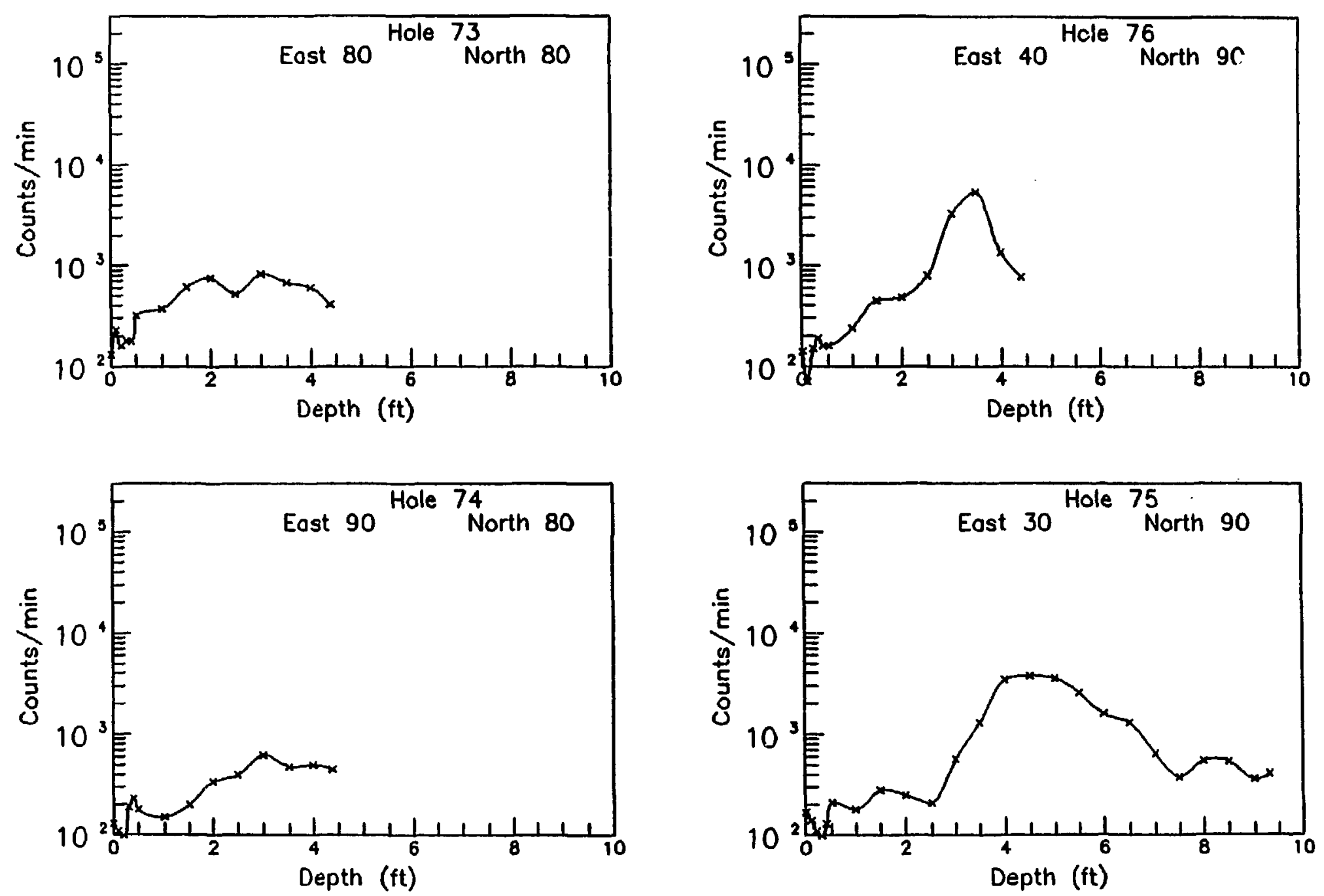

แ

Figure B19 Contamination Depth Profiles at Barrows Field Park, Glen Ridge, N.J. 

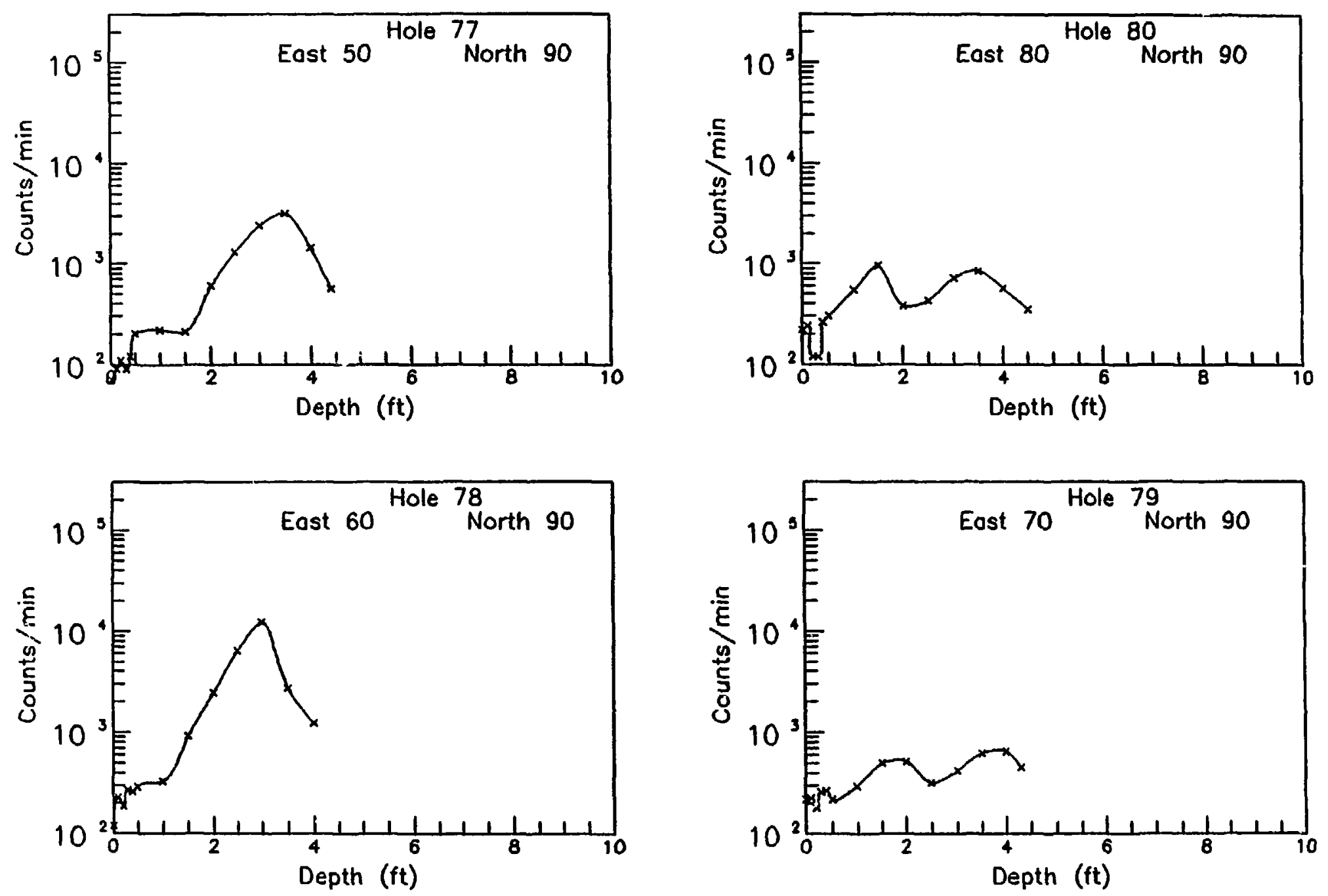

Figure B20 Contamination Depth Profiles at Barrows Field Park, Glen Ridge. N.J. 

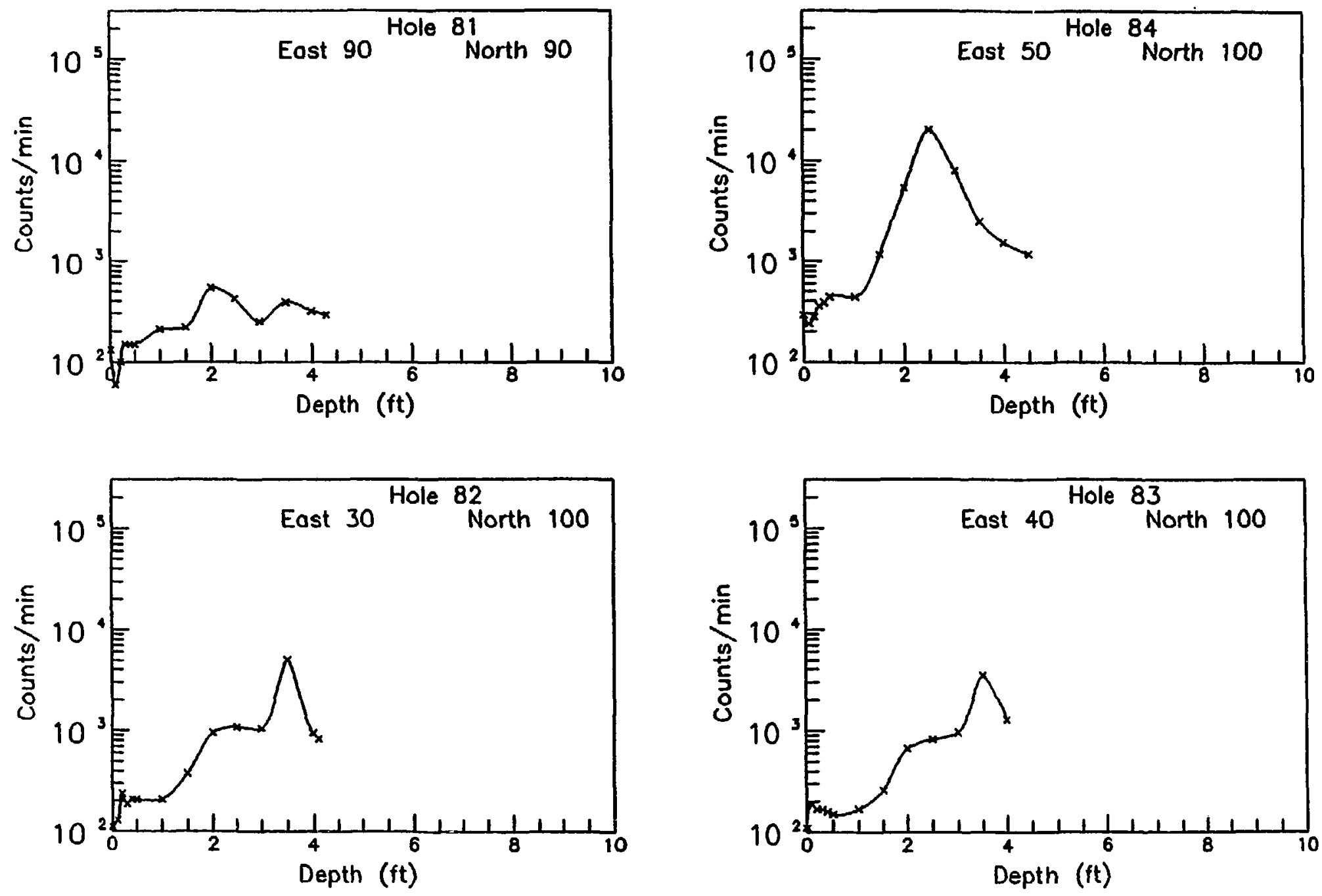

Figure B21 Contamination Depth Profiles at Barrows Field Park, Glen Ridge, N.J. 

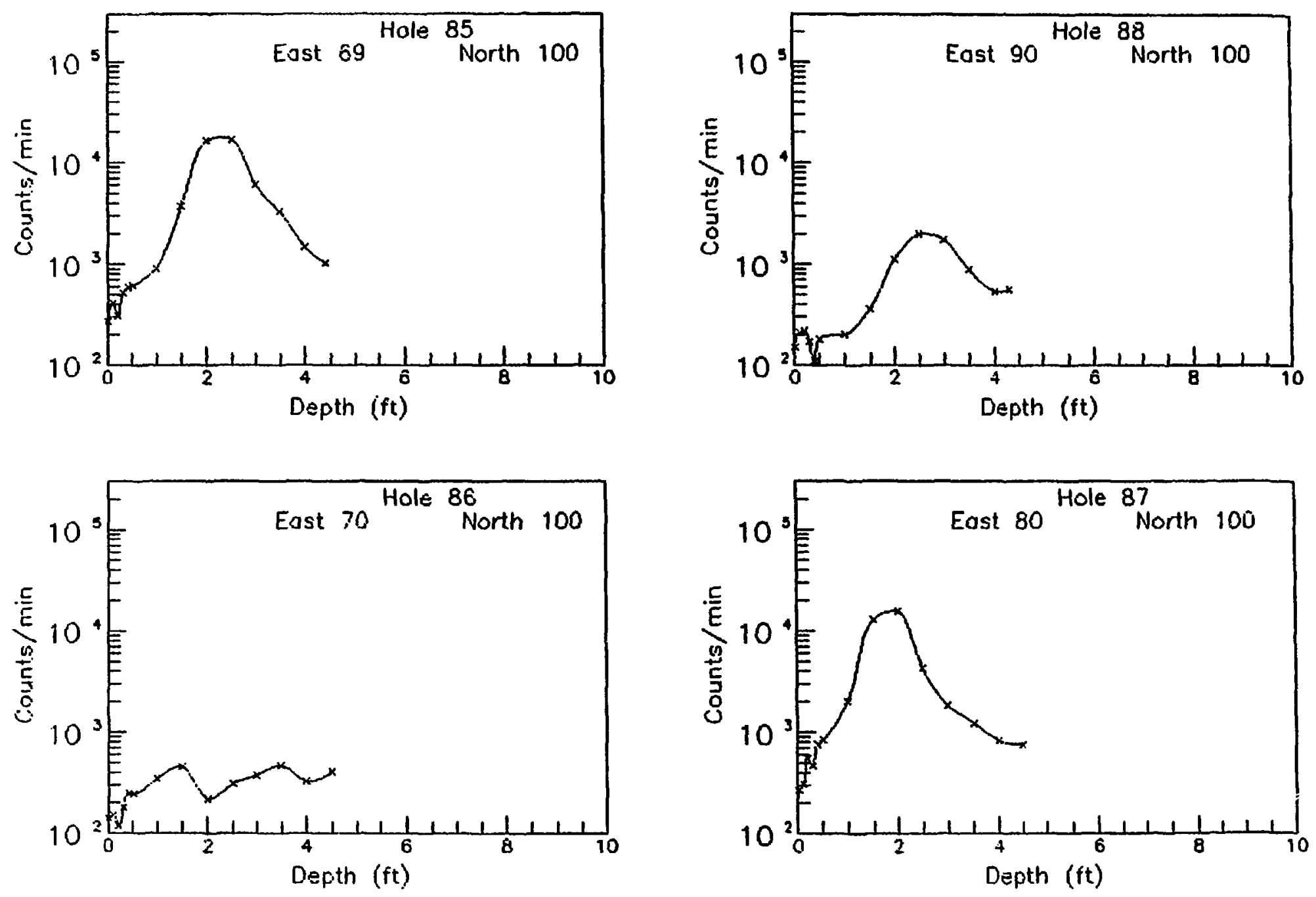

Figure 22 Contamination Depth Profiles at Barrows Field Park, Glen Ridge, N. J. 

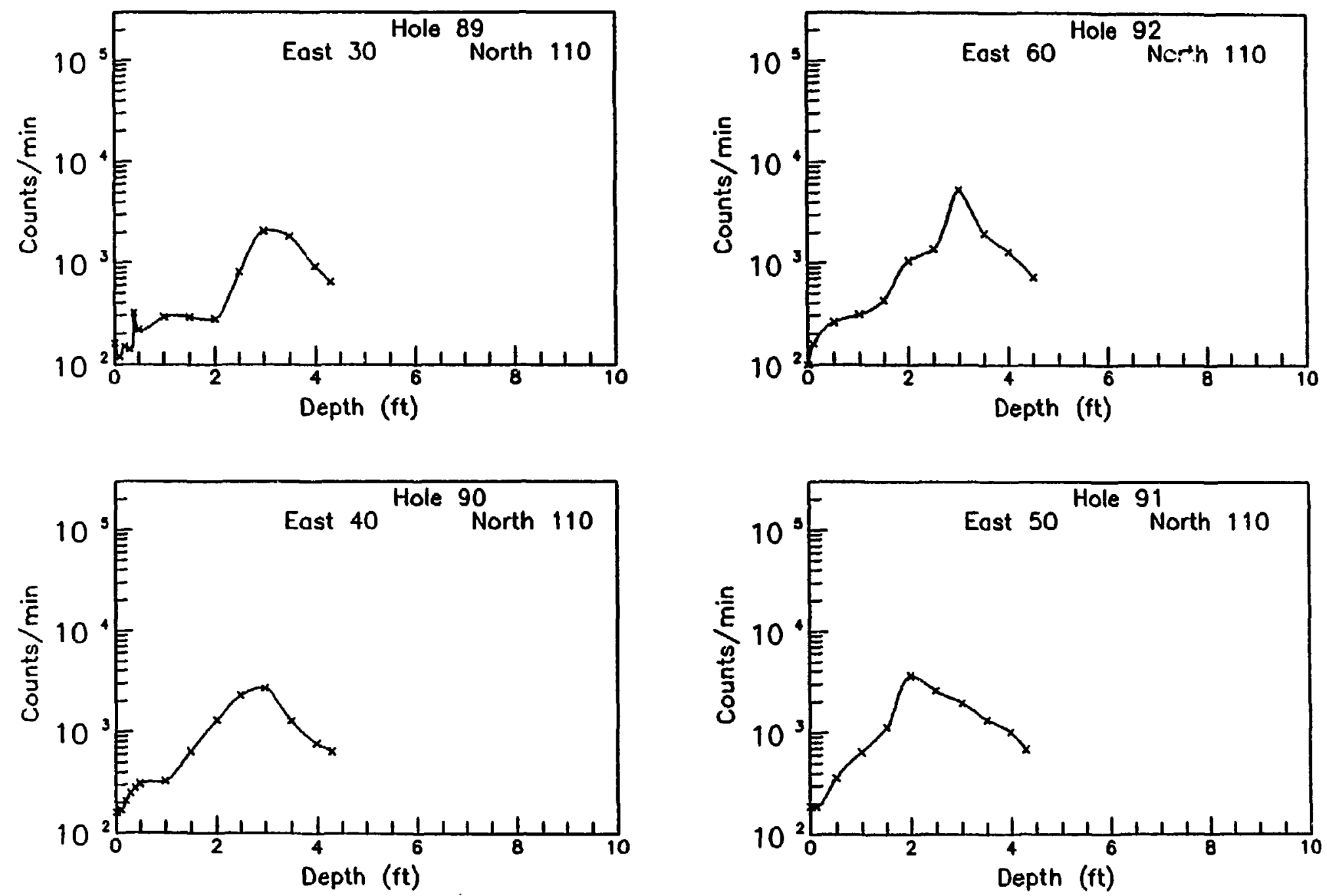

Figure B23 Contamination Depth Profiles at Barrows Field Park, Glen Ridge. N.J. 

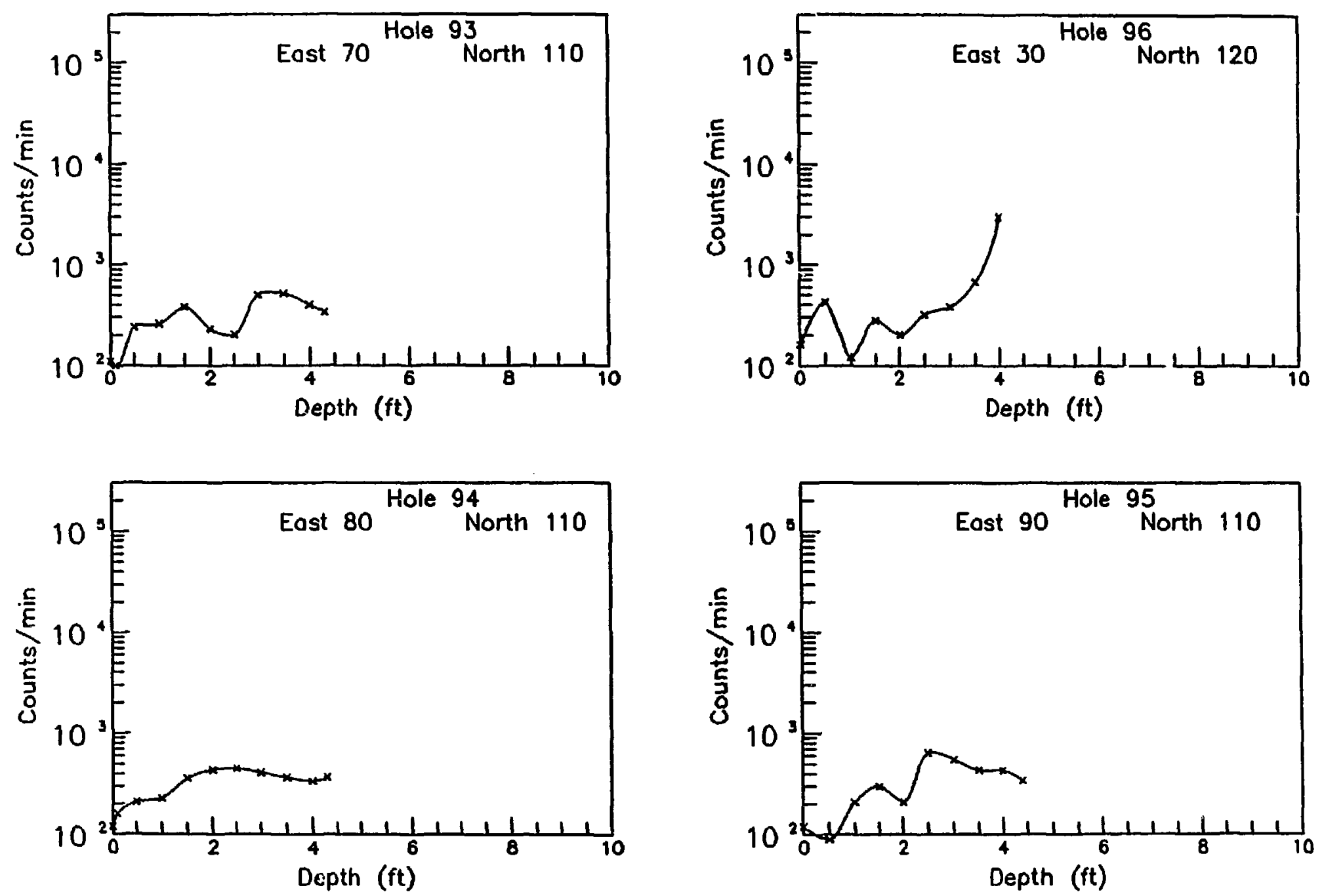

Figure B24 rontamination Depth Profiles at Barrows Field Park, Glen Ridge, N.J. 

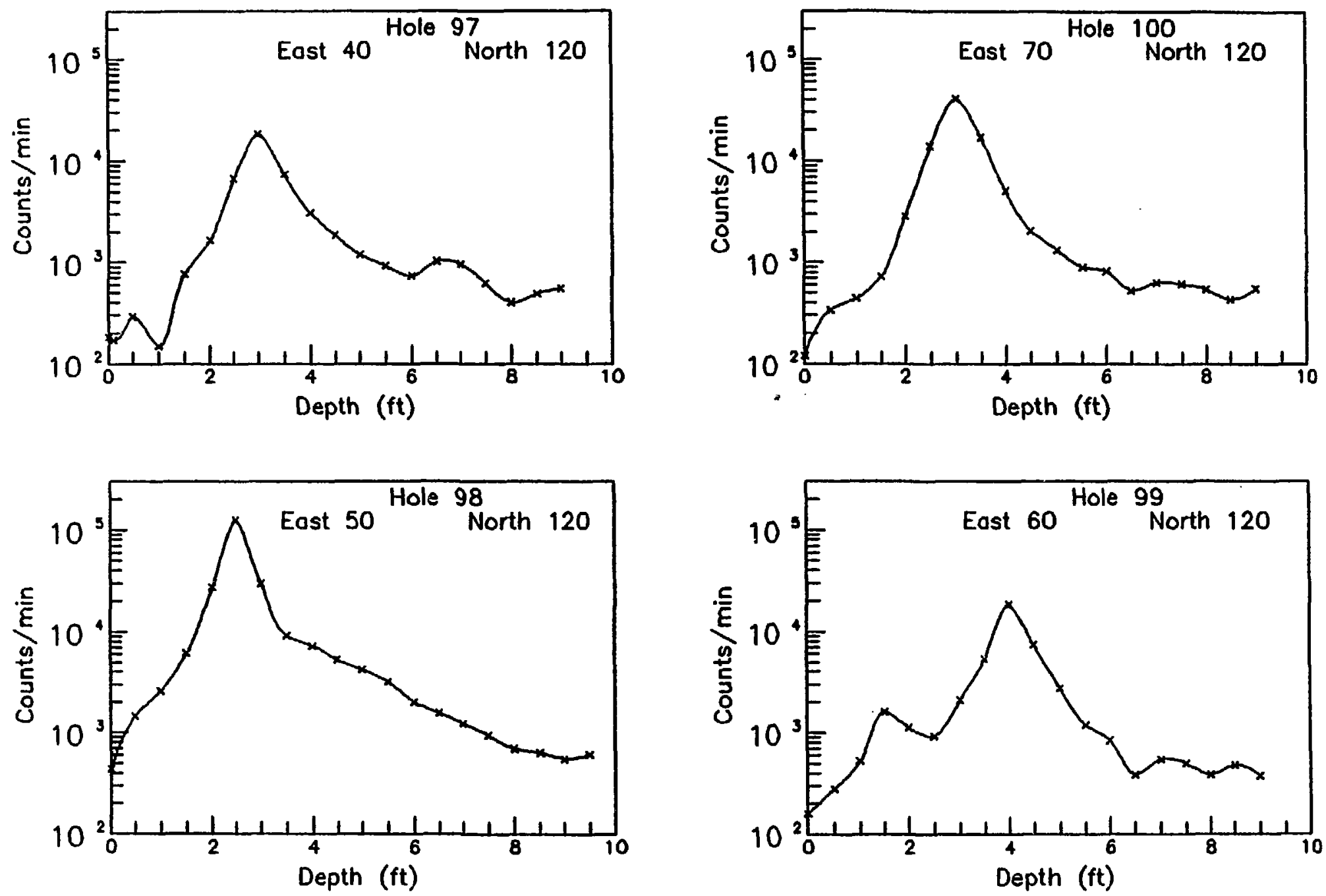

s

Figure B25 Contamination Depth Profiles at Barrow s Field Park, G̣len Ridge, N.J. 

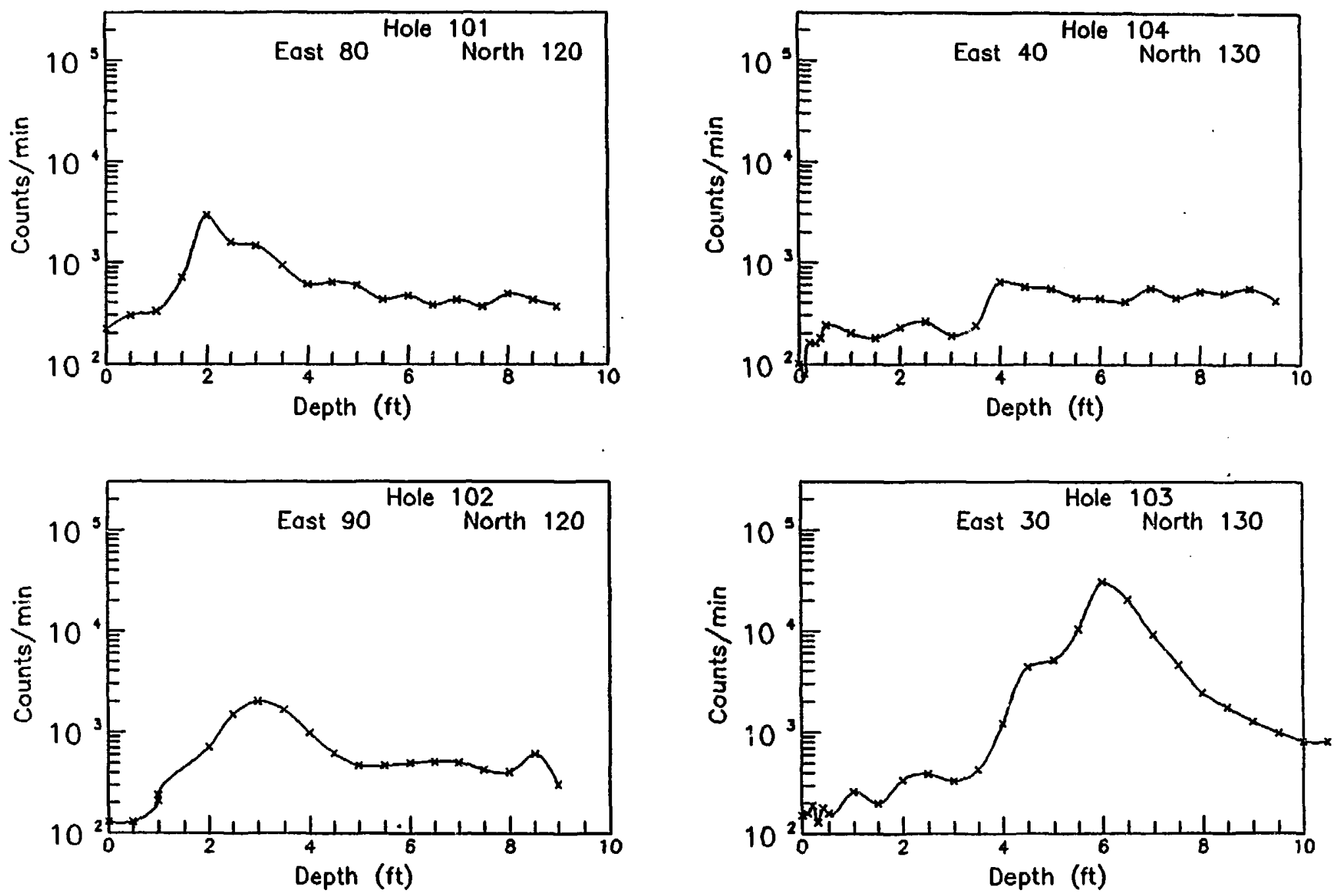

Figure B26 Contamination Depth Profiles at Barrows Field Park, Glen Ridge, N.J. 

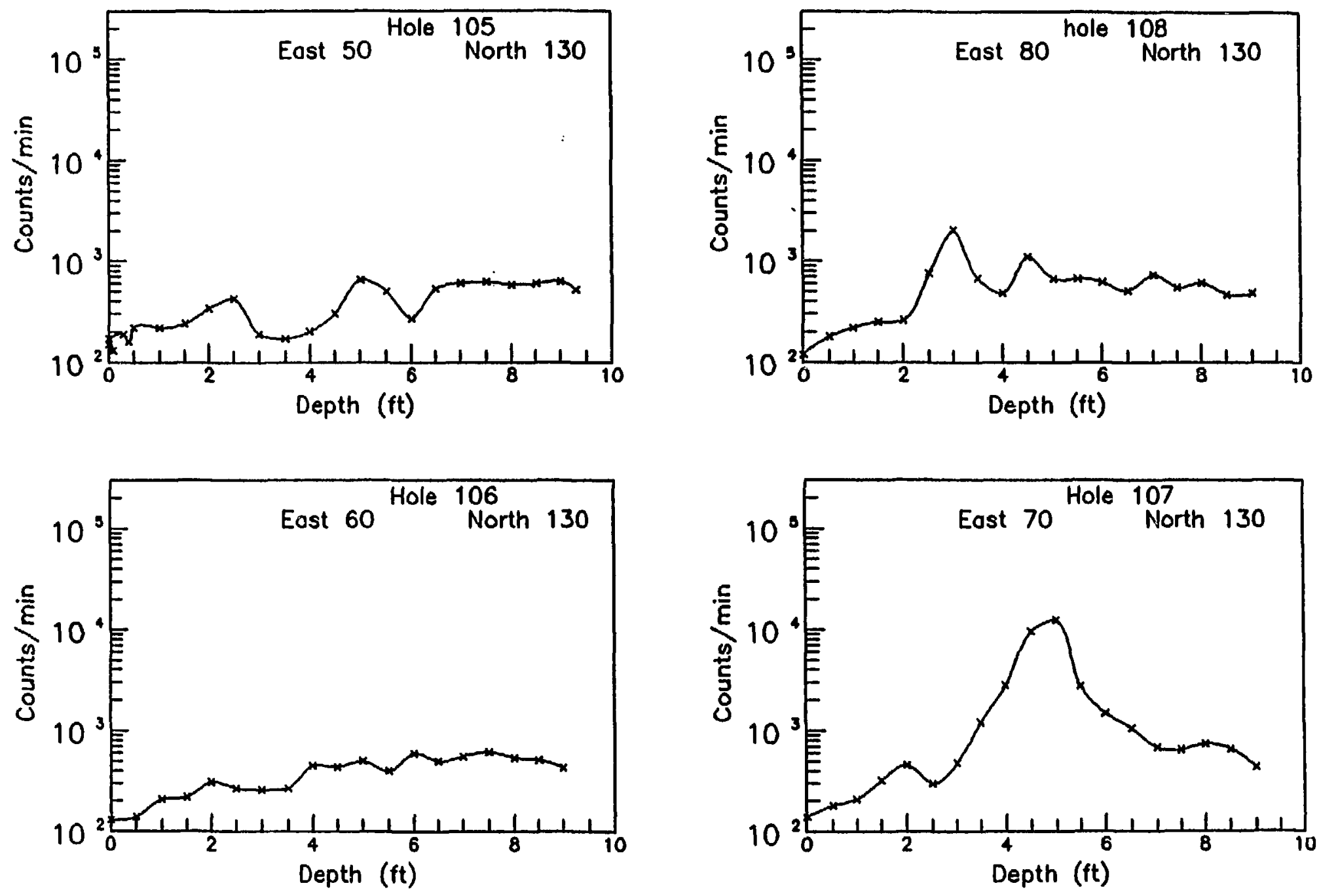

Figure B27 Contamination Depth Profiles at Barrows Field Park, Glen Ridge, N.J. 

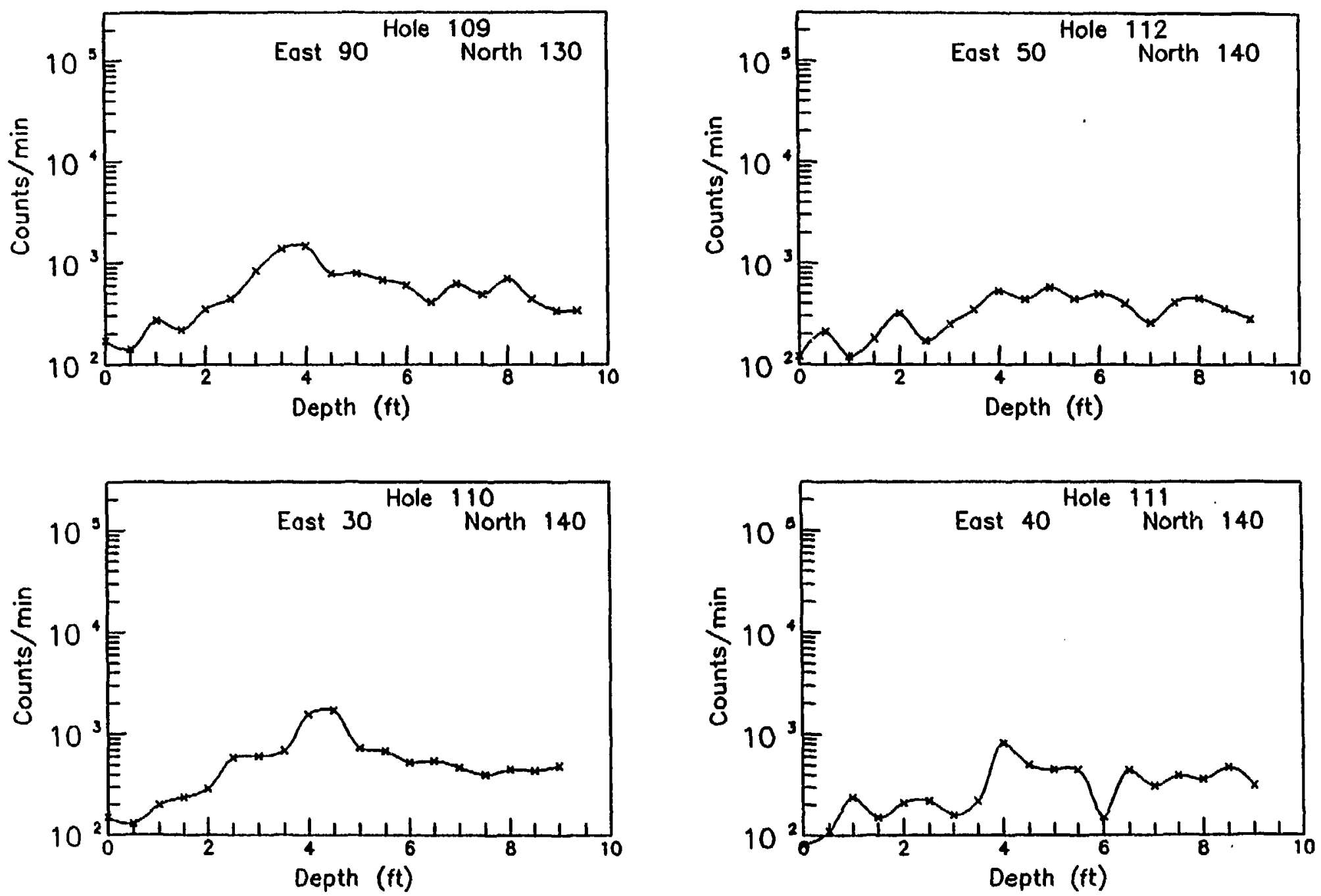

Figure B28 Contamination Depth Profiles at Barrows Field Park, Glen Ridge, N.J. 

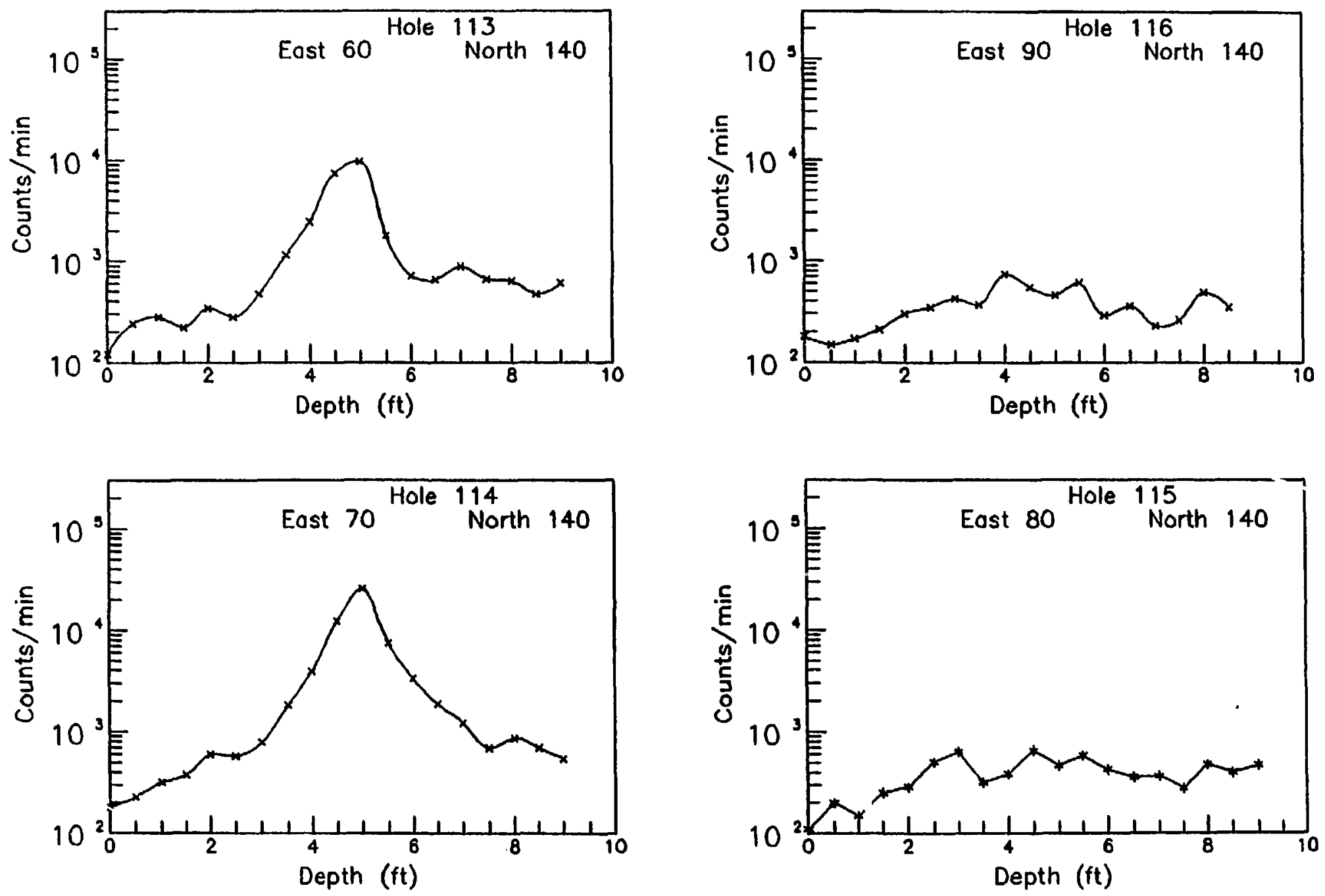

Figure B29 Contamination Depth Profile at Barrows Field Park, Glen Ridge, N.J. 

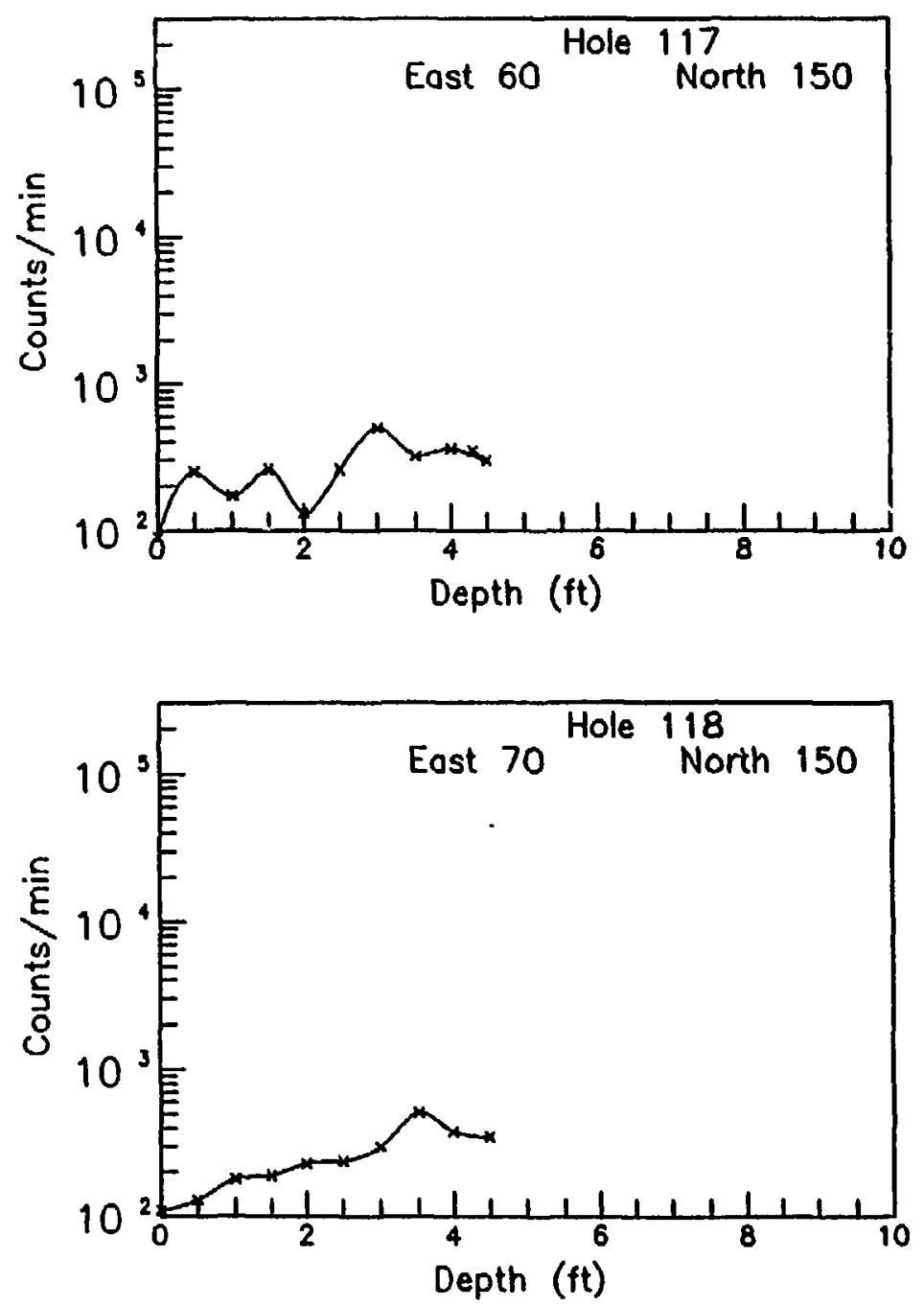

Figure B30 Contamination Depth Profiles at Barrows Field Park, Glen Ridge, N.J. 


\section{APPEATDIX C}

DEPTHS TO MAXIMUM CONCENTRATIONS 
Table Cl. Depths to Maximum Concentrations

\begin{tabular}{|c|c|c|c|c|}
\hline Tube No. & $\begin{array}{r}\text { Loc } \\
\text { East, }\end{array}$ & $\begin{array}{l}\text { tion } \\
\text { North } \\
\text { ) }\end{array}$ & $\begin{array}{l}\text { Max. Conc. } \\
\mathrm{pCi} \mathbf{2}^{\circ} \mathrm{Ra} / \mathrm{g}\end{array}$ & $\begin{array}{l}\text { Depth at } \\
\text { Max. Conc. } \\
\text { (ft) }\end{array}$ \\
\hline 1 & 49, & 11 & 124 & 2.0 \\
\hline 2 & 45. & 18 & 1014 & 1.7 \\
\hline 3 & 42 , & 25 & 1405 & 2.0 \\
\hline 4 & 35 & 22 & 780 & 1.5 \\
\hline 5 & 55 & 37 & 1952 & 2.0 \\
\hline 6 & 56 & 31 & 639 & 2.0 \\
\hline 7 & 60 & 5 & 155 & 1.3 \\
\hline 8 & 59, & 25 & 858 & 2.1 \\
\hline 9 & 56 , & 65 & 53 & 2.7 \\
\hline 10 & 76. & 96 & 468 & 1.7 \\
\hline 11 & 50 & 116 & 1718 & 2.5 \\
\hline 12 & 2 & 114 & 194 & 2.5 \\
\hline 13 & 0 & 10 & 1 & 3.5 \\
\hline 14 & 10 & 10 & 2 & 2.0 \\
\hline 15 & 20 & 10 & 5 & 2.7 \\
\hline 16 & 30 & 10 & 4 & 3.0 \\
\hline 17 & 40 & 10 & 17 & 1.5 \\
\hline 18 & 50 & 10 & 116 & 2.0 \\
\hline 19 & 60 & 10 & 108 & 1.5 \\
\hline 20 & 70 & 10 & 7 & 1.5 \\
\hline 21 & 80. & 10 & 3 & 3.0 \\
\hline 22 & 90 & 10 & 5 & 1.0 \\
\hline 23 & 100 & 10 & 3 & 0.5 \\
\hline 24 & 30 & 20 & 9 & 5.5 \\
\hline 25 & 40 & 20 & 116 & 1.5 \\
\hline 26 & 50 & 20 & 366 & 2.0 \\
\hline 27 & 60 & 20 & 108 & 2.0 \\
\hline 28 & 70 & 20 & 18 & 1.5 \\
\hline 29 & 80 & 20 & 3 & 1.0 \\
\hline 30 & 90 & 20 & 2 & 2.0 \\
\hline
\end{tabular}


Table C1. Depths to Maximum Concentrations

(Cont'd.)

\begin{tabular}{|c|c|c|c|c|}
\hline \multirow{2}{*}{$\frac{\text { Tube No. }}{31}$} & \multicolumn{2}{|c|}{$\begin{array}{l}\text { Location } \\
\text { East, North } \\
\text { (ft) }\end{array}$} & \multirow{2}{*}{$\begin{array}{l}\text { Max. Conc. } \\
\text { PCi-226Ra/g } \\
4\end{array}$} & \multirow{2}{*}{$\begin{array}{c}\text { Depth at } \\
\text { Max. Conc. } \\
\text { (ft) } \\
5.0\end{array}$} \\
\hline & 20 & 30 & & \\
\hline 32 & 30 & 30 & 5 & 5.0 \\
\hline 33 & 40 & 30 & 116 & 2.0 \\
\hline 34 & 50 & 30 & 311 & 2.3 \\
\hline 35 & 60 & 30 & 405 & 2.0 \\
\hline 36 & 70 & 30 & 14 & 1.5 \\
\hline 37 & 80 & 30 & 3 & 3.5 \\
\hline 38 & 90 & 30 & 3 & 2.5 \\
\hline 39 & 30 & 40 & 6 & 4.0 \\
\hline 40 & 36 & 40 & 108 & 2.5 \\
\hline 41 & 40 & 40 & 139 & 2.5 \\
\hline 42 & 50 & 40 & 311 & 2.5 \\
\hline 43 & 60 & 40 & 147 & 2.5 \\
\hline 44 & 70 & 40 & 30 & 3.4 \\
\hline 45 & 80 & 40 & 2 & 0.5 \\
\hline 46 & 90 & 40 & $?$ & $?$ \\
\hline 47 & 30 & 50 & 7 & 6.0 \\
\hline 48 & 40 & 50 & 30 & 2.5 \\
\hline 49 & 50. & 50 & 85 & 2.0 \\
\hline 50 & 60. & 50 & 25 & 3.0 \\
\hline 51 & 70 & 50 & 85 & 2.5 \\
\hline 52 & 80 & 50 & 14 & 2.0 \\
\hline 53 & 90 & 50 & 4 & 3.5 \\
\hline 54 & 30 & 60 & 6 & 3.0 \\
\hline 55 & 40 & 60 & 1983 & 3.0 \\
\hline 56 & 50 & 60 & 77 & 2.6 \\
\hline 57 & 60. & 60 & 22 & 2.5 \\
\hline 58 & 70 & 60 & 123 & 2.5 \\
\hline 59 & 80 & 60 & 202 & 2.0 \\
\hline 60 & 90 & 60 & 15 & 2.5 \\
\hline
\end{tabular}


Table C1. Depths to Maximum Concentrations

(Cont'd.)

\begin{tabular}{|c|c|c|c|c|}
\hline \multirow{2}{*}{$\begin{array}{c}\text { Tube No. } \\
61\end{array}$} & \multicolumn{2}{|c|}{$\begin{array}{l}\text { Location } \\
\text { East, North } \\
\text { (ft) }\end{array}$} & \multirow{2}{*}{$\begin{array}{c}\text { Max. Conc. } \\
\text { PCi-22 }{ }^{\circ} \mathrm{Ra} / \mathrm{g}\end{array}$} & \multirow{2}{*}{$\begin{array}{c}\begin{array}{c}\text { Depth at } \\
\text { Max. Conc. } \\
(f t)\end{array} \\
4.5\end{array}$} \\
\hline & 30 & 70 & & \\
\hline 62 & 40 , & 70 & 11 & 3.0 \\
\hline 63 & 50, & 70 & 77 & 3.0 \\
\hline 64 & 60 & 70 & 28 & 3.0 \\
\hline 65 & 70 & 70 & 18 & 2.5 \\
\hline 66 & 80 & 70 & 8 & 1.5 \\
\hline 67 & 90 , & 70 & 13 & 2.0 \\
\hline 68 & 30 , & 80 & 3 & 3.5 \\
\hline 69 & 40 & 80 & 7 & 4.0 \\
\hline 70 & 50 & 80 & 19 & 3.0 \\
\hline 71 & 60 & 80 & 18 & 3.0 \\
\hline 72 & 70 & 80 & 7 & 3.0 \\
\hline 73 & 80 , & 80 & 5 & 3.0 \\
\hline 74 & 90. & 80 & 3 & 3.0 \\
\hline 75 & 30 , & 90 & 30 & 4.5 \\
\hline 76 & 40 & 90 & 42 & 3.5 \\
\hline 77 & 50 & 90 & 26 & 3.5 \\
\hline 78 & 60 , & 90 & 93 & $\div 0$ \\
\hline 79 & 70 & 90 & 4 & 4.0 \\
\hline 80 & 80 & 90 & 6 & 1.5 \\
\hline 81 & 90, & 90 & 3 & 2.0 \\
\hline 82 & 30 , & 100 & 38 & 3.5 \\
\hline 83 & 40 & 100 & 26 & 3.5 \\
\hline 84 & 50, & 100 & 194 & 2.5 \\
\hline 85 & 60 & 100 & 139 & 2.3 \\
\hline 86 & 70 & 100 & $?$ & $?$ \\
\hline 87 & 80 , & 100 & 124 & 2.0 \\
\hline 88 & 90 , & 100 & 14 & 2.0 \\
\hline 89 & 30 & 110 & 15 & 3.0 \\
\hline 90 & 40, & 110 & 21 & 2.9 \\
\hline
\end{tabular}


Table C1. Depths to Maximum Concentrations (Cont'd.)

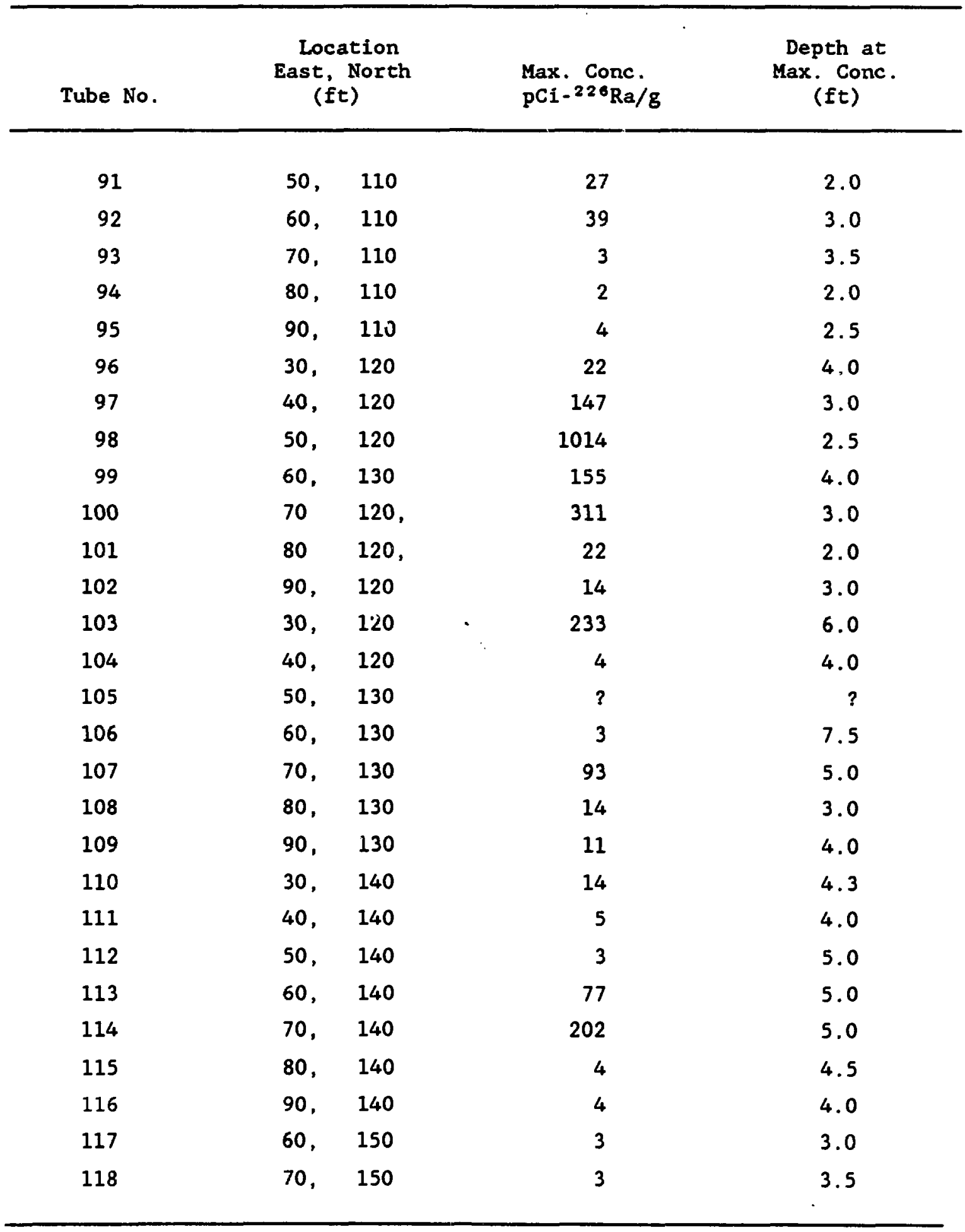




\section{INDEX}

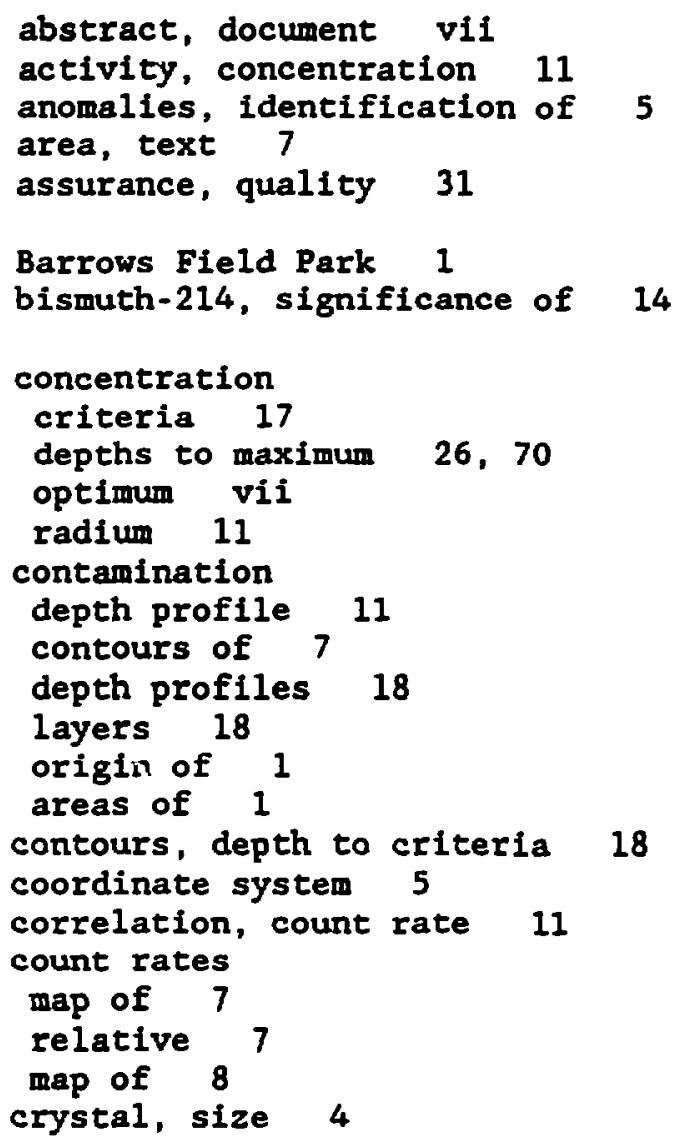


error bars 11

exposure rate measurements, height of 7

exposure rates, map of 9

field instruments, 11st of 34

field work, dates 7

Glen Ridge, location of 1

grids, size of 5

hammer, gasoline powered 3

hot spots, identification of 5

instruments, field 4,34

layers, contamination 18

Ludlum, rate meter/scaler 4

maximum concentrations, depths to 70

measurements, radiation 4

metal tubing, electrical 3

meter, microR 7

objective, project vil, 1

Park, Barrows Field 1

potassium-40, significance of 16

precision, of technique 31

profiles, shapes of 26

project

objective vii, 1

duration 7

quality assurance 31

radiation

aboveground measurements 7

check source 4

detectors 4

exposure-rate 7

measurements 4

rate meter/scaler 4

report, purpose of 1

samples, soil 1

scan, surface 5

scintillation detector, size of 7

soil samples

depths of 11

number collected 11

surface, scan 5

technique, precision of

31

test area, size of 7 
thickness, contaminated layer 26 tubes

diameter 3

length 3

locations of $5 ; 10$

method of driving 3

points 3

spacing 7

uncertainty, of estimate 31

uncertainty, of measurements 11

volume estimates

purpose of 1

technique 3

volumes

calculation of 30

in-place estimate 30

wall thickness, tube 3 